MARCELO GASQUE FURTADO

\title{
A FORMAÇÃO DO CIDADÃO CONFORME A CONSTITUIÇÃO DA REPÚBLICA FEDERATIVA DO BRASIL DE 1988
}

\begin{abstract}
Dissertação apresentada à banca examinadora da Faculdade de Direito da Universidade de São Paulo, como exigência parcial para obtenção do título de Mestre em Direito, sob, sob orientação do Professor Doutor José Sérgio Fonseca de Carvalho.
\end{abstract}

FACULDADE DE DIREITO DA UNIVERSIDADE DE SÃO PAULO SÃO PAULO 


\section{FOLHA DE APROVAÇÃO}

FURTADO, M. G. A formação do cidadão conforme a Constituição da República

Federativa do Brasil de 1988. Dissertação apresentada à Faculdade de Direito da Universidade de São Paulo para obtenção do título de Mestre em Direito.

Aprovado em:

\section{Banca Examinadora:}

Prof. Dr. Instituição:

Julgamento: Assinatura:

Prof. Dr. Instituição:

Julgamento: Assinatura:

Prof. Dr. Instituição:

Julgamento: Assinatura: 
Para Angelina (in memoriam) pelo passado;

Para Uliana, Vilma, Sandra e Maria Inês pelo presente;

Para Sofia pelo futuro. 


\section{AGRADECIMENTOS}

Em Hamlet, há um trecho que sempre me impressionou.

Trata-se de uma fala do próprio príncipe da Dinamarca. Após receber a trupe de atores no palácio, Hamlet pede a Polônio para acomodá-los e o lacaio responde que vai tratá-los conforme eles merecem.

Em resposta, Hamlet diz a frase que reproduzo livremente: “Ora, Polônio, se fores tratar os homens conforme eles merecem, a verdade é que ninguém escaparia do chicote. Então, trate-os conforme a tua própria honra e dignidade. Quanto menor merecimento eles tiverem, maior será a tua generosidade".

A lembrança dessa fala vem a propósito de homenagear e agradecer ao meu orientador, José Sérgio Fonseca de Carvalho, que a despeito de minhas limitações pessoais, acolheu-me com confiança e dedicação que só vieram a provar o seu grande valor, não só de intelectual comprometido e acadêmico rigoroso, mas também de ser humano generoso e acolhedor.

Agradeço também aos meus amigos e amigas que fizeram parte da turma ingressante no programa de pós-graduação em Direitos Humanos no ano de 2007 e aos que integram o Grupo de Estudos de Educação e Pensamento Contemporâneo, por tudo o que o convívio amistoso e desinteressado pode gerar de ânimo quando desanimamos e de esperanças quando nos desesperançamos.

Agradeço aos professores do programa de pós para os quais reservo as minhas melhores memórias.

Agradeço à minha família pela paciência durante esse período tão difícil, tão solitário e também pela impaciência, que às vezes se revela mais útil.

Agradeço à Fundação Ford pela bolsa- auxílio no período inicial do programa de pós-graduação. 


\section{RESUMO}

FURTADO, Marcelo Gasque. A formação do cidadão conforme a Constituição da República Federativa do Brasil de 1988. 148f . Dissertação (Mestrado) - Faculdade de Direito, Universidade de São Paulo, São Paulo, 2010

A Constituição Federal de 1988 prevê o preparo para o exercício da cidadania como uma das finalidades da educação nacional. Esta dissertação é um esforço interdisciplinar entre as áreas de Direito e Pedagogia aplicado ao estudo dessa diretriz constitucional. Considerando o modo de vida contemporâneo, consumista, competitivo e desinteressado pelas responsabilidades públicas, como compreender o papel da cidadania? Predomina, no entendimento popular, a idéia de que cidadania é gozo de direitos sociais concedidos de forma paternalista pelo Estado, indicando o diagnóstico muito recorrente de que faltaria aos brasileiros uma cultura cívica. Há uma intensa retórica em torno da importância da formação para a participação ativa do cidadão nos negócios públicos embora os interesses da própria Educação sejam cada vez mais utilitários e voltados para a obtenção de êxito econômico. O presente trabalho parte das dificuldades conceituais que envolvem o sentido de educação e cidadania no próprio texto constitucional e também nos discursos sociais e bibliografia especializada, com o objetivo de fazer uma contribuição para a reflexão sobre o papel da Educação na formação do cidadão participativo, condição indispensável para o fortalecimento do regime democrático no Brasil.

Palavras-chave: Cidadania. Educação. Constituição Federal de 1988. Participação política. 


\section{RIASSUNTO}

La Costituzione Federale di 1988 predica il preparo per l'esercizio della cittadinanza come una delle finalità della educazione nazionale. Questa dissertazione è uno sforzo interdisciplinare tra il Diritto e la Pedagogia applicata allo studio di questa direttiva costituzionale. Considerando che il modo di vita contemporaneo, consumistico, competitivo ed disinteressato per le responsabilità pubblice, come comprendere il ruolo della cittadinanza? Predomina, nell'intendimento popolare, l'idea che la cittadinanza è il godimento dei diritti sociali concessero di forma paternalista dallo Stato, indicando la diagnosi molto ricorrente che ai brasiliani mancherebbe una cultura cívica. C'è una retorica intensa circa l'importanza della formazione per la partecipazione attiva dei cittadini alla cosa pubblica nonostante gli interessi della propria Educazione siano ogni volta più utilitari e voltati ad ottenere successo economico. Il presente studio parte delle difficoltà concettuali che circonda il senso dell'educazione e della cittadinanza nel próprio testo costituzionale ed anche nei discorsi sociali e letteratura professionale, con lo scopo di fare un contributo al dibattito ruolo dell'Educazione nella formazione dei cittadini partecipativi, una condizione imprescindibile per il rafforzamento del regime democratico in Brasile.

Parole chiave: Cittadinanza. Educazione. Costituzione Federale di 1988. Partecipazione politica. 


\section{SUMÁRIO}

INTRODUÇÃO 8

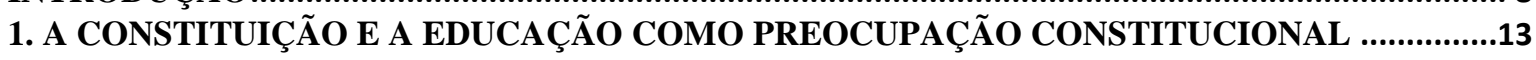

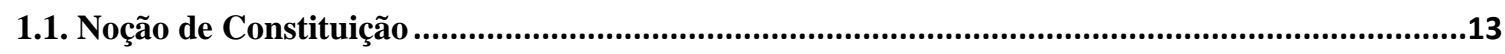

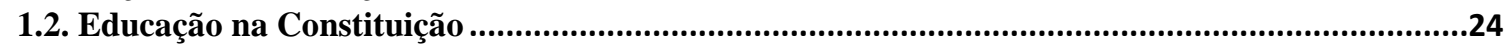

2. A LINGUAGEM DA EDUCAÇÃO E A LINGUAGEM DA CONSTITUIÇÃ̃o...............................31

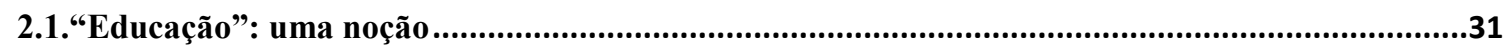

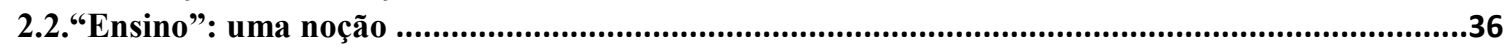

2.3. Educação e Ensino na Constituição de 1988 ........................................................................................37

3. NOÇÃO DE CIDADANIA ..................................................................................................................47

3.1. Polissemia da palavra "cidadania": observações de natureza lingüística ....................................47

3.2. Cidadania em três tempos ...........................................................................................................53

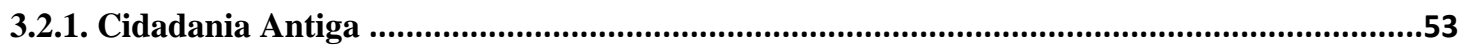

3.2.2. Cidadania Liberal .......................................................................................................................62

3.2.3. Cidadania sob a égide do Estado Social de Bem Estar .............................................................67

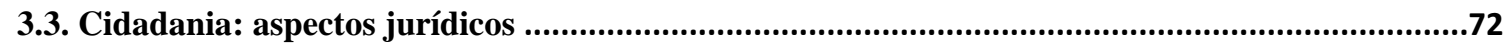

3.3.1. Cidadania sob enfoque jurídico-constitucional........................................................................72

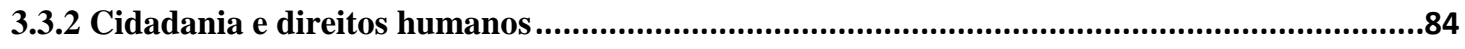

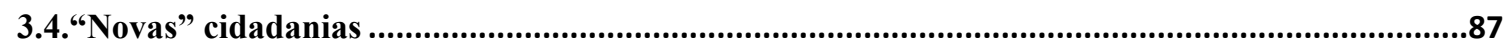

3.4.1. Cidadania Global .......................................................................................................................89

3.4.2. "Empresa-cidadã" ...................................................................................................................90

3.4.3. Cidadania, organizações não-governamentais e filantropia .....................................................91

3.4.4. A pulverização de designações .....................................................................................................93

4. CIDADANIA E EDUCAÇÃo EM UM CONTEXTO DE DECLÍNIO DA POLÍTICA NO MUNDO

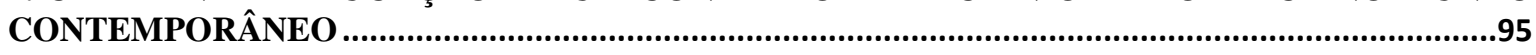

4.1. A vitória do consumidor sobre o cidadão ……................................................................................95

4.2. A dissolução do senso comum .....................................................................................................102

4.3. A perda do sentido público da educação .......................................................................................104

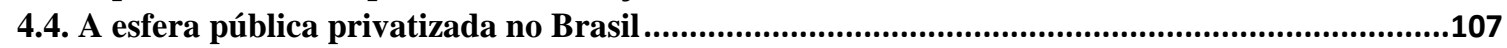

5. EDUCAÇÃO PARA A CIDADANIA PARTICIPATIVA................................................................112

5.1. Formação do cidadão e educação do povo …………………………………………….....................113

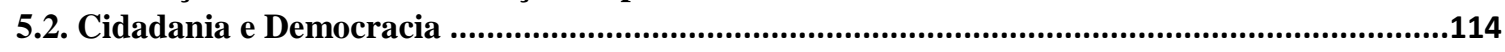

5.3. Cidadania participativa e a noção de "direito a ter direitos" ........................................................115

5.4. Participação política e proteção jurídica .....................................................................................118

5.4.1. O direito à educação como um direito político ..........................................................................125

5.5. Os discursos da negação, do resgate, da consciência e da construção .......................................127

6. CONCLUSÃO

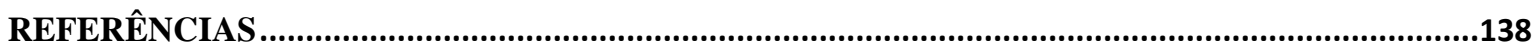




\section{INTRODUÇÃO}

O Brasil é um país de múltiplas carências. Qualquer mesa redonda, seminário, simpósio, congresso ou o nome que se queira dar a encontros entre especialistas que se proponham a discutir qualquer assunto de interesse público, seja agricultura, transporte coletivo, trânsito, desenvolvimento econômico, criminalidade, saneamento básico, saúde, trabalho, distribuição de renda, meio ambiente, direitos humanos, cultura, ciência, racismo, etc., terá grande probabilidade de, em algum momento, ser o palco de discursos que apontam, em praticamente todas essas áreas, "faltas" que tornam o nosso país o que ele é: "falta verba", "falta investimento", "falta maior participação e cobrança popular", "falta vontade política", "falta ética", "falta aplicar a lei", "falta comprometimento de nossos dirigentes", "falta um projeto de país", entre outras.

Talvez, de todas as "faltas", aquela mais recorrente é a que diz respeito às nossas deficiências no campo da educação. Principalmente e acima de tudo, "falta educação".

Comumente se diz que a nossa insuficiência em inúmeros setores da vida nacional e a pouca relevância do país na comunidade internacional decorreria, em parte, de questões educacionais mal resolvidas. A educação é vista por amplos segmentos da sociedade como uma espécie de caminho para "a salvação nacional".

Os discursos muitas vezes espelham visões de natureza econômica apontando a educação como a chave para projetos individuais (preparo para um mercado de trabalho cada vez mais especializado, ascensão social por meio da educação, melhoria econômica familiar etc.) e para projetos coletivos (desenvolvimento do país, maior inserção competitiva do Brasil no mercado internacional etc.).

Ao mesmo tempo, a educação também é entendida em um papel de natureza política, necessária à construção da democracia, capaz de educar homens e mulheres para as decisões e escolhas que afetam o seu destino comum, promover uma cultura de paz e de respeito pelas diferenças individuais e culturais, propiciar práticas que conduzam a um espírito de fraternidade e de cooperação entre os indivíduos de uma comunidade e entre os povos do mundo.

Se há certo consenso genérico no que diz respeito à importância da educação, parece que há divergências quando se passa a refletir sobre os propósitos que guiariam essa educação. 
Assim, diante da cacofonia de discursos que procuram sugerir sentidos para a educação, consideramos pertinente voltar à atenção para a fonte de maior legitimidade das aspirações da República que é a nossa própria Constituição. Assim, a nossa proposta é analisar o sentido da educação nacional a partir do artigo 205 da Constituição Federal de 1988, destacando a finalidade do preparo para o exercício da cidadania.

Portanto, a nossa abordagem tangenciará as áreas de Direito e de Educação, de forma interdisciplinar.

Prevê o artigo 205 da Constituição Federal: “a educação, direito de todos e dever do estado e da família, será promovida e incentivada com a colaboração da sociedade, visando ao pleno desenvolvimento da pessoa, seu preparo para o exercício da cidadania e sua qualificação para o trabalho."

Essas finalidades dão à educação um papel absolutamente extraordinário na configuração do próprio projeto de construção do nosso país, que até justifica o quanto dela se espera, pois não podemos deixar de considerar a correlação dessas finalidades com os fundamentos do Estado Democrático de Direito instaurado no Brasil com a Constituição de 1988. Diz o art. $1^{\circ}$ da Constituição de 1988:

\footnotetext{
A República Federativa do Brasil, formada pela união indissolúvel de Estados Municípios e do Distrito Federal, constitui-se em Estado Democrático de Direito e tem com fundamentos:$$
\text { (...) }
$$$$
\text { II- a cidadania }
$$$$
\text { III- a dignidade da pessoa humana }
$$$$
\text { IV- os valores sociais do trabalho e da livre iniciativa }
$$$$
\text { (...) }
$$

Correlacionando esses fundamentos com as finalidades da educação nacional, conforme o art. 205 tem-se:

- dignidade da pessoa humana (art. $1^{\circ}$, II) e pleno desenvolvimento da pessoa;

- cidadania (art. $1^{\circ}$, III) e preparo para o exercício da cidadania;

- valor social do trabalho (art. $1^{\circ}$, IV) e qualificação para o trabalho.

Essa ligação entre educação e fundamentos do Estado Democrático de Direito, as altas expectativas que se tem em relação ao papel da educação no Brasil como solução para uma miríade de problemas do país e a relevância da educação sob uma perspectiva de direitos humanos, já que a educação é um direito fundamental em si mesmo e ao mesmo 
tempo a chave para fruição dos outros direitos, nos leva a considerar relevante a busca de um delineamento dos sentidos possíveis albergados nessas finalidades.

Para os limites do presente trabalho, como já apontamos, iremos nos deter apenas na finalidade "preparo para o exercício da cidadania".

Sabemos que a questão da cidadania no Brasil é um problema de difícil equacionamento, mesmo considerando os evidentes avanços do nosso país em todos os aspectos, desde a sua constituição como nação independente. Os traços característicos de formação histórica do Brasil, nunca foram condizentes para a afirmação da igualdade como uma idéia reguladora da vida cotidiana do meio social brasileiro.

Predominam, nas análises sobre o perfil da sociedade brasileira, as características de sociedade hierárquica, patrimonialista, desigual, para a qual faltaria "cultura cívica".

Em um contexto mundial mais geral, vivemos tempos de declínio da política, afastamento e desinteresse dos indivíduos em relação às questões do mundo público. A atividade política que outrora foi à deliberação entre cidadãos sobre os assuntos mais importantes para a comunidade, desaparece para dar lugar ao poder de escolha de consumidores isolados sobre assuntos cada vez mais irrelevantes, como a "votação" eletrônica em reality shows.

Além disso, como teremos a oportunidade de demonstrar, a própria noção de cidadania, embora pareça uma unanimidade nos discursos, é objeto de grande controvérsia.

Vera Maria Candau retrata bem essa questão:

Cidadania é uma palavra que todos afirmam e defendem. Representantes das mais variadas posições políticas e ideológicas incorporaram/incorporam nos seus discursos a sua importância e apresentaram/apresentam suas propostas na ótica de reforçá-la e promovê-la.

Liberais e neoliberais. Populistas e socialistas. Organismos internacionais e movimentos sociais. Empresários, operários, funcionários, profissionais liberais, educadores, trabalhadores rurais. Homens e mulheres, Hétero e homossexuais. Adultos, jovens e crianças. Afro-descendentes, povos originários e brancos. Os diferentes sujeitos e atores sociais são unânimes na incorporação da palavra cidadania com um valor positivo. No entanto, por detrás desse aparente consenso existe uma pluralidade de enfoques, concepções e questões concretas. (2008, p.10)

Evidentemente, a própria dificuldade de estabelecer uma noção de cidadania repercute na concepção de educação para contemplá-la.

Assim, pensar na formação para o exercício da cidadania, partindo da própria Constituição Federal, parece-nos uma reflexão relevante não só pela permanência do nosso 
conhecido déficit histórico em cidadania mesmo após mais de duas décadas da promulgação da "Constituição Cidadã", como também pela oportunidade de tentarmos esclarecer e dimensionar melhor sobre o que se está falando quando se diz "educar para a cidadania" em um mundo com características desfavoráveis à política.

Como se vê, não se trata de uma especulação no sentido de apontarmos quais deveriam ser os objetivos da educação, mas um estudo que partirá do que já foi estabelecido pela Constituição Federal de 1988, como fins da educação, detendo-nos no preparo para o exercício da cidadania.

Também não se trata de efetuar estudo empírico para de descrever práticas docentes conforme se desenvolvem nas instituições de ensino ou aferir se o objetivo de preparar para a cidadania está sendo atingido ou não, embora as citações de exemplos que levem em conta esses aspectos possam vir a ocorrer. Tampouco nos deteremos em prescrever novas metodologias de ensino que operacionalizem a consecução desse fim nas práticas do ensino adotadas pelas escolas.

O nosso enfoque é teórico e envolve uma reflexão sobre o sentido da formação do cidadão tomando a Constituição da República como ponto de partida.

Em suma, este trabalho se propõe a estudar o sentido de educar para o exercício da cidadania a partir da configuração dada pela Constituição Federal de 1988, em uma abordagem que transita entre as áreas de Direito e Educação e pode ser visto como um esforço interdisciplinar que procura integrar esses universos.

O nosso problema geral seria assim enunciado: no que consistiria o "preparo para o exercício da cidadania”, indicado pela Constituição de 1988?

Metodologicamente, nos restringiremos à pesquisa bibliográfica, enfocando a consulta em obras na área de Direito Constitucional, Direitos Humanos, Educação, Ciência Política e Filosofia.

Estruturamos o presente trabalho em cinco capítulos.

Como se trata de discorrer sobre uma diretriz contida no texto constitucional, o primeiro capítulo terá como objetivo oferecer um panorama geral sobre a própria noção de constituição, discorrendo sobre as principais características dessa norma e sua diferença em relação às demais leis em uma visão que se pretende simplificada e didática, na medida do possível, para atender a leitores não restritos à área jurídica. As referências teóricas dominantes nesse capítulo serão obras de alguns importantes constitucionalistas e publicistas brasileiros como José Afonso da Silva, Dalmo Dallari, Celso Antônio Bandeira 
de Melo, Luís Roberto Barroso e de pensadores políticos clássicos como John Locke e Siéyès.

Estabelecida uma noção de Constituição, o segundo capítulo tem a finalidade de adentrar no texto constitucional para examinar os sentidos do termo "educação" buscando identificar o enfoque dado pela Constituição de 1988. Nesse capitulo faremos um esforço hermenêutico no sentido diferenciar "ensino" e "educação", para os fins constitucionais. As referências teóricas para esse capítulo são em parte da área de Direito, como Celso Bastos e Maria Garcia e em parte da área da Filosofia da Educação, como R.S. PETERS.

Se o nosso propósito é discutir o significado constitucional da educação para a cidadania, parece-nos natural a preocupação com o significado contemporâneo do próprio termo "cidadania". Dessa forma, o capítulo três terá a finalidade de indicar que, sob uma aparente unanimidade de entendimento, "cidadania" é um repositório de muitos significados, muitos deles conflitantes, o que traz conseqüências para a formação do cidadão. Faremos um panorama sobre a noção de cidadania desde o seu surgimento na Antiga Grécia, até a utilização de noções contemporâneas como cidadania corporativa. Faremos uso de referências clássicas como Aristóteles, estudiosos do mundo grego como Jean-Pierre Vernant e Moses Finley, além de referências de análise da cidadania moderna como Norberto Bobbio e da cidadania no Estado de bem estar, na leitura clássica de Marshall a respeito da consolidação dos direitos de cidadania na Inglaterra.

No capítulo quatro traçaremos um breve panorama da dissolução da esfera pública engolfada por solicitações da esfera privada e o declínio da política na era moderna, o que naturalmente impacta na noção de cidadania e de educação, tendo como referência básica algumas perspectivas de análise da pensadora Hannah Arendt.

No capítulo cinco discutiremos a educação para o exercício da cidadania enquanto preparo para a cidadania participativa, tendo como base teórica estudiosos com Maria Victória de Mesquita Benevides e José Sérgio Fonseca de Carvalho, entre outros. 


\title{
1. A CONSTITUIÇÃo E A EDUCAÇÃ̃O COMO PREOCUPAÇÃo CONSTITUCIONAL
}

A proposta desta dissertação é analisar a finalidade de educar para o exercício da cidadania em conformidade com o previsto na Constituição da República de 1988, sendo conveniente fazer algumas considerações sobre o próprio conceito de Constituição, tendo em vista que continua válida, a nosso ver, a advertência de Ferdinand Lassalle:

\begin{abstract}
Qual é a verdadeira essência de uma Constituição? Em todos os lugares e a toda hora, à tarde, pela manhã e a noite, estamos ouvindo falar de Constituição e de seus problemas constitucionais. Na imprensa, nos clubes, nos cafés e nos restaurantes, é este o assunto obrigatório de todas as conversas. E, apesar disso, ou por isso mesmo, formulada em termos precisos esta pergunta: qual será a verdadeira essência, o verdadeiro conceito de uma Constituição?, estou certo de que, entre essas milhares de pessoas que falam da mesma, existem muito poucos que possam dar-nos uma resposta satisfatória (1980, p.9)
\end{abstract}

Evidentemente que a nossa intenção é singela, e se concentrará em destacar didática e panoramicamente alguns aspectos que são mais relevantes para as nossas preocupações: as características fundamentais de uma constituição e a inserção da educação como preocupação constitucional.

\subsection{Noção de Constituição}

Em primeiro lugar convém dispor que "constituição" é uma noção moderna ${ }^{1}$, contemporânea das revoluções burguesas e, portanto, veículo das soluções políticas e jurídicas aplicadas ao problema da limitação e organização do poder pós-absolutismo.

\footnotetext{
${ }^{1}$ Como explica Luís Roberto Barroso "o constitucionalismo moderno, fruto das revoluções liberais, deu à idéia de constituição sentido, forma e conteúdos específicos. É certo, contudo, que tanto a noção como o termo constituição já integravam a ciência política e o Direito de longa data, associados à configuração do poder em diferentes fases da humanidade, da Antigüidade clássica ao Estado moderno. Nessa acepção mais ampla e menos técnica, é possível afirmar que todas as sociedades políticas ao longo dos séculos tiveram uma Constituição, correspondente à forma de organização e funcionamento de suas instituições essenciais" (2006, p.145). Dalmo Dallari, no mesmo sentido diz que "no sentido comum da palavra todos os povos sempre tiveram uma constituição, assim como se diz que todas as coisas formadas de diversas partes são constituídas dessas partes. Mas com a significação técnica, dada pelos políticos e pelos juristas, nem mesmo os grandes monumentos legislativos da Antigüidade podem ser chamados de Constituição, pois esta tem certas particularidades de forma e de conteúdo que não se encontram em nenhum documento de antes do século XVII". (1986, p.3)
} 
Tradicionalmente diz-se que o seu surgimento concreto pode ser indicado no século XVIII, nos Estados Unidos, com a elaboração da Constituição do Estado da Virgínia.

Embora anteriormente a esse marco tenha havido, no decorrer da História do Ocidente, documentos jurídicos que traduziam certas características que também encontramos hoje nas cartas que chamamos de "constituição", o conjunto das condições culturais e políticas correspondentes à Modernidade, mais especificamente ao jusnaturalismo e ao Iluminismo é que puderam de fato configurá-la.

Estamos nos referindo, de forma geral, ao pensamento político que se desenvolvia na época, com a contribuição de pensadores como Locke, Rousseau, Montesquieu entre outros e às lutas e revoluções que se opuseram ao domínio colonial (Estados Unidos) e ao Antigo Regime (França) e acarretaram a reconfiguração das estruturas de poder pósabsolutismo, afirmando a preeminência dos direitos individuais.

É nesse sentido que o artigo $2^{\circ}$ da Declaração Universal do Homem e do Cidadão de $1789^{2}$ diz que "o objetivo de toda associação política é preservação dos direitos naturais e imprescritíveis do homem. Esses direitos são a liberdade, a propriedade, a segurança e a resistência à opressão".

É a materialização da concepção jusnaturalista moderna, ou seja, da existência de direitos inerentes ao homem, anteriores e superiores às normas emanadas de um poder constituído, sem que se recorra ao fundamento em uma divindade transcendente. Ao contrário da concepção jusnaturalista de fundamento teológico, os direitos naturais nesse contexto baseiam-se em uma pretensa natureza humana apreensível pela razão. Para garantir esses direitos, os homens unem-se em sociedade de tal sorte que a organização política formada tem o dever de proteção dos indivíduos, abstendo-se de interferir na esfera de liberdade os indivíduos (contratualismo). Para ficarmos em um exemplo influente dessa visão, apresentaremos rapidamente a concepção de John Locke. A sociedade politicamente organizada, segundo Locke, não surge para acrescentar nada de essencial ao que o homem já dispõe no estado de natureza. Para Locke, a passagem do estado de natureza para o

\footnotetext{
2 A declaração Universal dos Direitos do Homem aprovada em 26/08/1789 pela Assembléia Nacional francesa é sem dúvida o documento mais influente e representativo de todo o ideário político que emergiu no século XVIII. Segundo Dalmo Dallari, "é fora de dúvida que essa Declaração, cuja influência na vida constitucional dos povos, não só do Ocidente como também do Oriente, ainda hoje é marcante, representou um considerável progresso na história da afirmação dos valores fundamentais da pessoa humana. Entretanto, como um produto do século XVIII, seu cunho é nitidamente individualista subordinando a vida social ao indivíduo e atribuindo ao Estado a finalidade de conservação dos direitos individuais". (2002, p. 208). Eric Hobsbawn comenta que a declaração é um "manifesto contra a sociedade hierárquica de privilégios da nobreza, mas não um manifesto a favor de uma sociedade democrática e igualitária”. (2004, p.20)
} 
estado civil implica na manutenção das liberdades e da propriedade que o indivíduo já tem no estado de natureza e não na repressão e na transformação de suas características naturais. Assim, o homem não precisa abdicar de seus direitos e transferi-los para o soberano, mas a organização política deverá garantir ao homem uma melhor fruição de seus direitos naturais que não precisam ser abandonados com o seu ingresso na sociedade política. A sociedade política estaria a serviço do indivíduo proporcionando a ele as condições de segurança necessárias para o desenvolvimento de suas potencialidades e o gozo de direitos que lhe são próprios.

Nas palavras de Locke:

\begin{abstract}
Se o homem no estado de natureza é tão livre, conforme dissemos, se é senhor absoluto da sua própria pessoa e posses, igual ao maior e a ninguém sujeito, por que abrirá ele mão dessa liberdade, por que abandonará o seu império e sujeitarse-á ao domínio de qualquer outro poder? Ao que é óbvio responder que, embora no estado de natureza tenha tal direito, a fruição do mesmo é muito incerta e está constantemente exposta à invasão de terceiros porque, sendo todos reis tanto quanto ele, todo homem igual a ele, e na maior parte pouco observadores da eqüidade e da justiça, a fruição da propriedade que possui nesse estado é muito insegura, muito arriscada. Estas circunstâncias obrigam-no a abandonar uma condição que, embora livre, está cheia de temores e perigos constantes; e não é sem razão que procura de boa vontade juntar-se em sociedade com outros que estão já unidos, ou pretendem unir-se para a mútua conservação da vida, da liberdade e dos bens a que chamo "propriedade". (LOCKE, 1983, p.82)
\end{abstract}

Em função da prevenção da burguesia em ascensão no tocante à ingerência do Poder Estatal, cuja experiência mais presente era o absolutismo monárquico, pode-se dizer que a definição das garantias do indivíduo em relação ao poder do Estado foi, originalmente, a característica principal da idéia de Constituição, juntamente com a noção de separação de poderes, que também é mais um elemento de garantia contra arbitrariedades. Essas diretrizes, inclusive, aparecem claramente expressas no art. 16 da Declaração Universal dos Direitos do Homem e do Cidadão de 1789 que diz: "não possui Constituição a sociedade em que a garantia dos direitos não esteja assegurada ou a separação dos poderes estabelecida".

A questão da limitação do poder é de fato um problema central nas formulações dos principais pensadores políticos que contribuíram no desenvolvimento do constitucionalismo. Montesquieu, por exemplo, em sua obra fundamental $O$ Espírito das Leis, promoverá uma defesa da divisão de poderes como forma de limitação do uso do poder, pois, em suas palavras, "trata-se de uma experiência eterna que todo homem que possui poder é levado a dele abusar; ele vai até onde encontra limites”. (2005, p.166) 
A vinculação da idéia de constituição e a formação do Estado Liberal são evidenciadas justamente pela intensa preocupação com a organização e limitação de poder do Estado e a garantia dos direitos civis, como as liberdades de opinião e de religião, a garantia de propriedade, entre outros e os direitos políticos. Esse enfoque em "liberdades" participa da própria denominação da concepção política que vai tomando forma, que é o liberalismo.

É de se notar, entretanto, que essas garantias constitucionais de liberdade foram concebidas por e para indivíduos que reuniam as condições de serem proprietários. A partir final do século XIX e principalmente no século XX, foram se agregando as demandas de atores que sempre estiveram ocultos do cenário público, como os trabalhadores nãoproprietários e as mulheres, entre outros, dando corpo a uma nova gama de direitos que não faziam parte das preocupações iniciais do liberalismo, os chamados direitos sociais, caracterizadores de uma nova forma de concepção estatal: o Estado Social, ou de Bem Estar.

O formato liberal de Estado focado na determinação de seus limites de atuação, em sua organização e em direitos de liberdade teve um alargamento de suas matérias, passando a ter um papel relevante no campo sócio-econômico. Assim, novas demandas foram se agregando à idéia básica de constituição calcada na ideologia liberal, ampliando as matérias que compõem o conteúdo a ser tratado em nível constitucional. ${ }^{3}$

Focando, então, a nossa atenção para o conteúdo de uma constituição, em sua formatação contemporânea, podemos dizer com Luis Roberto Barroso, que as normas constitucionais podem ser classificadas em três categorias: "as que organizam o poder político (normas constitucionais de organização), as que definem os direitos fundamentais (normas constitucionais definidoras de direitos) e as que indicam princípios e fins públicos (normas constitucionais de princípio ou programáticas)”. (2009, p.90)

\footnotetext{
${ }^{3}$ Por outro lado, em função do predomínio do neoliberalismo e a retomada de certas diretrizes liberais clássicas como o afastamento do Estado da economia, temos em nossa própria constituição de 1988 alguns exemplos de novas reformulações retirando do Estado atribuições de natureza econômica, tidas como excessivas. Assim, por exemplo, o art. 21, XI originariamente previa que era competência da União explorar diretamente ou por meio de concessão a empresas de controle acionário estatal, os serviços de telefonia. O inciso XI foi modificado por meio da emenda constitucional $n^{\circ} 8$ de 15/08/98 e atualmente prevê que é competência da União "explorar, diretamente ou mediante autorização, concessão ou permissão, os serviços de telecomunicações, nos termos da lei, que disporá sobre a organização dos serviços, a criação de um órgão regulador e outros aspectos institucionais". Como se nota, foi quebrada a preponderância do Estado na administração dos serviços de telecomunicações sendo amplamente franqueada à iniciativa privada. A contrapartida da saída do Estado do controle desses serviços foi a criação de uma agência estatal para regular o setor, a ANATEL, criada pela lei 9472 de 16/07/97.
} 
As normas constitucionais de organização expressam a função mais originalmente básica de uma constituição, ou seja, instrumentalizar, dar corpo e órgãos ao exercício do poder político e materializam-se em subtipos normativos, que mantém essa característica mais geral de promover a organização do Estado. Segundo BARROSO (2009, p.93-94), as normas constitucionais de organização ${ }^{4}$ seriam aquelas que:

(A) veiculam decisões políticas fundamentais ao definirem a forma de Estado e de governo ${ }^{5}$, a divisão orgânica do poder ${ }^{6}$ ou o sistema de governo ${ }^{7}$;

(B) definem as competências dos órgãos constitucionais ${ }^{8}$

(C) criam órgãos públicos ${ }^{9}$, autorizam sua criação ${ }^{10}$, traçam regras à sua composição ${ }^{11}$ e ao seu funcionamento ${ }^{12}$;

(D) estabelecem normas processuais ou procedimentais: de revisão da própria constituição $^{13}$, de defesa da constituição ${ }^{14}$, de aplicação de outras normas ${ }^{15}$, de elaboração legislativa ${ }^{16}$, de fiscalização ${ }^{17}$.

\section{As normas constitucionais definidoras de direitos veiculam os direitos}

fundamentais que, contemporaneamente, expressam-se em uma lista mais ampla do que

\footnotetext{
${ }^{4}$ As normas constitucionais de organização são exemplificadas nas notas abaixo, com artigos retirados da Constituição Federal de 1988. Os exemplos são citados conforme BARROSO (2009, p 93-94).

5“Art. $1^{\circ}$. A República Federativa do Brasil, formada pela união indissolúvel dos Estados e Municípios e do Distrito Federal, constitui-se em Estado Democrático de Direito."

6 “Art. 2 ${ }^{\circ}$. São Poderes da União, independentes e harmônicos entre si, o Legislativo, o Executivo e o Judiciário."

7 “Art. 76. O Poder Executivo é exercido pelo Presidente da República, auxiliado pelos Ministros de Estado".

8 “Art. 49. É da competência exclusiva do Congresso Nacional..."; "Art. 84. Compete privativamente ao Presidente da República..." "Art. 96. I. Compete privativamente aos Tribunais..."

9 “Art. 44. O Poder Legislativo é exercido pelo Congresso Nacional, que se compõe da Câmara dos Deputados e do Senado Federal."

10 “Art. 125. Os Estados organizarão sua Justiça, observados os princípios estabelecidos nesta Constituição.

(...)§ $3^{\circ}$ A lei estadual poderá criar, mediante proposta do Tribunal de Justiça, a Justiça Militar estadual, constituída, em primeiro grau, pelos juízes de direito e pelos Conselhos de Justiça e, em segundo grau, pelo próprio Tribunal de Justiça, ou por Tribunal de Justiça Militar nos Estados em que o efetivo militar seja superior a vinte mil integrantes."

11،Art. 101. O Supremo Tribunal Federal compõe-se de onze Ministros, escolhidos dentre cidadãos com mais de trinta e cinco e menos de sessenta e cinco anos de idade, de notável saber jurídico e reputação ilibada.”

12، Art. 93 II, a) é obrigatória a promoção do juiz que figure por três vezes consecutivas ou cinco alternadas em lista de merecimento; (...)"

13 “Art. 60, $\S 4^{\circ}$ - Não será objeto de deliberação a proposta de emenda tendente a abolir: I - a forma federativa de Estado (...).

14 “Art. 102. Compete ao Supremo Tribunal Federal, precipuamente, a guarda da Constituição, cabendo-lhe: I - processar e julgar, originariamente: a) a ação direta de inconstitucionalidade de lei ou ato normativo federal ou estadual e a ação declaratória de constitucionalidade de lei ou ato normativo federal (...)

15 “Art. 102. Compete ao Supremo Tribunal Federal, precipuamente, a guarda da Constituição, cabendo-lhe (...)III - julgar, mediante recurso extraordinário, as causas decididas em única ou última instância, quando a decisão recorrida (...)"

16 “Art. 47. Salvo disposição constitucional em contrário, as deliberações de cada Casa e de suas Comissões serão tomadas por maioria dos votos, presente a maioria absoluta de seus membros."

17 "Art. 71. O controle externo, a cargo do Congresso Nacional, será exercido com o auxílio do Tribunal de Contas da União, ao qual compete (...)II - julgar as contas dos administradores e demais responsáveis por dinheiros, bens e valores públicos da administração direta e indireta, incluídas as fundações e sociedades instituídas e mantidas pelo Poder Público federal, e as contas daqueles que derem causa a perda, extravio ou outra irregularidade de que resulte prejuízo ao erário público";(...)
} 
aquela indicada na concepção liberal clássica. A constituição de 1988 contempla uma carta de direitos composta por direitos civis; direitos políticos; direitos sociais (forma reduzida de referência a direitos de conteúdos econômicos, sociais e culturais) e os direitos difusos. Os direitos civis correspondem às garantias de liberdade no âmbito individual como liberdade de expressão e liberdade de religião; os direitos políticos correspondem às garantias de participação política, principalmente por meio do voto; os direitos sociais correspondem às garantias de igualdade material de acesso ao trabalho, à saúde, à educação etc; os direitos difusos correspondem aos direitos de titularidade não determinada, que pertencem a todos sem pertencer a um indivíduo em exclusão dos outros, como é o caso do direito a um meio ambiente saudável.

As normas constitucionais programáticas referem-se, de forma genérica, a indicações dos fins gerais da organização política instituída pela constituição, está impregnada de valores e aspirações da comunidade, e é um parâmetro a servir de guia para as decisões políticas e escolhas individuais. Na constituição de 1988, é exemplo dessa modalidade de norma o art. 170, in verbis: “A ordem econômica, fundada na valorização do trabalho humano e na livre iniciativa, tem por fim assegurar a todos existência digna, conforme os ditames da justiça social, observados os seguintes princípios: (...)”.

A esta altura seria conveniente atentarmos para algumas das características mais importantes de uma constituição. Destacaremos algumas conceituações propostas por grandes publicistas, para delas retirarmos os pontos que consideramos relevantes para os nossos fins.

A primeira conceituação que apresentaremos é de José Afonso da Silva:

\begin{abstract}
A constituição do Estado, considerada sua lei fundamental, seria, então, a organização dos seus elementos essenciais: um sistema de normas jurídicas, escritas ou costumeiras, que regula a forma do Estado, a forma de seu governo, o modo de aquisição e o exercício do poder, o estabelecimento de seus órgãos, os limites de sua ação, os direitos fundamentais do homem e as respectivas garantias. Em síntese, a constituição é o conjunto de normas que organiza os elementos constitutivos do Estado. (2008, p.37-38)
\end{abstract}

Nesse conceito, destaca-se o caráter normativo da constituição sendo apresentada como um conjunto de normas jurídicas aplicadas, em linhas gerais, à organização do Estado. Enfatizemos aqui, portanto, esses aspectos característicos de uma constituição: é uma norma jurídica; é uma norma que organiza os elementos essenciais do Estado.

A segunda conceituação que apresentaremos é de Dalmo Dallari: 


\begin{abstract}
A Constituição é a declaração de vontade política de um povo, feita de modo solene por meio de uma lei que é superior a todas as outras e que, visando a proteção e a promoção da dignidade humana, estabelece direitos e as responsabilidades fundamentais dos indivíduos, dos grupos sociais, do povo e do governo (1986, p.21-22).
\end{abstract}

Dallari destaca que a constituição visa a "proteção e a promoção da dignidade humana". É em torno desse ideal maior que a constituição organiza o Estado administrativamente e distribui as responsabilidades entre os integrantes da nação.

Aponta Dallari, como José Afonso da Silva, para o fato de a constituição ser uma norma jurídica, destacando inclusive que essa lei "é superior a todas as outras". Esse é um ponto absolutamente imprescindível para a idéia de constituição: a sua superioridade ou supremacia dentro de um ordenamento jurídico.

Celso Antônio Bandeira de Mello é enfático a esse respeito quando afirma:

\begin{abstract}
(...) a Constituição não é um mero feixe de leis, igual a qualquer outro corpo de normas. A Constituição, sabidamente, é um corpo de normas qualificado pela posição altaneira, suprema, que ocupa no conjunto normativo. É a Lei das Leis. É a Lei Máxima, à qual todas as demais se subordinam e na qual todas se fundam. É a lei de mais alta hierarquia. É a lei fundante. É a fonte de todo o Direito. É a matriz última da validade de qualquer ato jurídico". (2009, p. 12)
\end{abstract}

Se a constituição é a lei máxima de um Estado, de onde viria a sua legitimidade, já que acima dela não haveria nenhuma norma positiva?

Para elucidarmos melhor tal característica de superioridade é preciso comentar outro aspecto indicado por Dalllari em sua definição, que é a afirmação de que a constituição é "uma declaração de vontade política de um povo".

Portanto, além de ser uma norma jurídica, a constituição guarda um caráter político. A autoridade de uma constituição do ponto de vista jurídico provém de uma força política que é anterior à própria formulação do texto constitucional.

Fazendo uma pequena digressão, é importante apontar que, para descrever a origem legítima de uma constituição, a doutrina do Direito Constitucional faz uso da teoria do poder constituinte, concebida por Sieyès em um opúsculo denominado “Qu'est-ce que le Tiers État" [O que é o Terceiro Estado?], cuja publicação data de 1789. Essa obra está inserida no contexto da Revolução Francesa de tal sorte que, conforme explica Aurélio Wander Bastos, "o livro não antecede a Revolução nem ao menos lhe sucede: sua dinâmica é a dinâmica da própria Revolução”. (SIEYÈS, 2009, p. xxxi) 
A ordem jurídica conforme se apresentava às vésperas da Revolução Francesa era baseada em uma tradição que privilegiava a nobreza e o clero em detrimento do Terceiro Estado que, embora destituído de vantagens e afastado da possibilidade de participar politicamente, tinha um papel preponderante na geração da riqueza do país.

São conhecidas as perguntas e respostas concisas com as quais Sieyès pretende desenvolver sua obra e que são anunciadas em suas considerações preliminares: "O que é o Terceiro Estado? - Tudo", "O que tem sido ele, até agora, na ordem política? - Nada"; "O que ele pede? - Ser alguma coisa". (2009, p. lvii)

A estrutura jurídica de privilégios só teria condições de ser superada por uma força criadora que não poderia estar limitada por nenhuma lei positiva anterior, já que se assim fosse nenhuma mudança real das condições vigentes poderia ser pretendida.

Assim, uma constituição, segundo Sieyès, “... não é obra do poder constituído, mas do poder constituinte.” (2009, p.55). O poder constituinte é atributo da nação, e exercido por delegados extraordinários indicados para exercê-lo, conforme ainda assim expôs:

\footnotetext{
A nação se forma unicamente pelo direito natural. O governo, ao contrário, só se regula pelo direito positivo (...) Na verdade, de quem [a nação] teria podido receber uma formalização positiva? Existe alguma autoridade anterior que pudesse dizer a uma multidão de indivíduos: Eu vos reúno sob tais leis; vós formareis uma nação nas condições que vos prescrevo? (2009, p. 56-57)
}

Então, a legitimidade de uma constituição, a sua supremacia em relação a todos os poderes que são por ela constituídos e em relação às normas que são produzidas sob a sua vigência, se deve ao fato de se originar em um poder fundante cuja titularidade é o povo, ou seja, o poder constituinte.

A teoria do Direito Constitucional faz uma diferença entre poder constituinte originário e poder constituinte derivado.

O poder constituinte originário é justamente esse poder sobre o qual tecemos as considerações acima, ou seja, se destina à criação de uma constituição, de um novo ordenamento jurídico, uma nova ordem política. Ele se caracteriza por ser inicial, ilimitado e incondicionado. Inicial por originar, ser o marco zero de uma nova ordem jurídica; ilimitado por não estar vinculado a nenhuma norma jurídica anterior e, incondicionado pelo fato de não estar sujeito a manifestar-se respeitando a formas ou procedimentos predeterminados.

O poder constituinte derivado, tem essa designação porque extrai sua legitimidade do poder constituinte originário, é limitado pelas determinações da Constituição posta, e 
condicionado quanto à forma de manifestação. Esse poder derivado se materializa no poder constituinte dos Estados-membro da federação para elaborarem as suas respectivas constituições estaduais e também no poder que permite a reforma da constituição federal por meio de emendas.

A forma de expressão legítima do poder constituinte originário é a Assembléia Constituinte e o poder constituinte derivado, na modalidade de reforma constitucional, se processa, no caso do Brasil, no âmbito do próprio Congresso Nacional instituído pela constituição.

Sobre o problema da reforma do texto constitucional, a supremacia da constituição no ordenamento jurídico pressupõe a sua rigidez, ou seja, que a alteração de suas normas seja realizada por meio de um procedimento diferenciado e mais exigente (em termos de quórum, notadamente) em relação à formulação da legislação comum.

A Constituição de 1988 é uma constituição rígida, pois prevê mecanismos de alteração especiais. Trata-se do processo legislativo de emenda constitucional. Note-se, portanto que rigidez constitucional não significa imutabilidade, mas permite uma abertura controlada com rigor para evitar leviandades, para adequação do texto constitucional à dinâmica das mudanças sociais. A nossa atual constituição já foi emendada 62 vezes, o que demonstra que, embora seja um processo mais dificultoso, tem sido amplamente utilizado.

$\mathrm{O}$ art. 60 da Constituição trata dos requisitos para a propositura e aprovação de uma emenda constitucional, nos seguintes termos:

\footnotetext{
A Constituição poderá ser emendada mediante proposta:

I - de um terço, no mínimo, dos membros da Câmara dos Deputados ou do Senado Federal;

II - do Presidente da República;

III - de mais da metade das Assembléias Legislativas das unidades da Federação, manifestando-se, cada uma delas, pela maioria relativa de seus membros.

$\S 1^{\circ}$ - A Constituição não poderá ser emendada na vigência de intervenção federal, de estado de defesa ou de estado de sítio.

$\S 2^{\circ}$ - A proposta será discutida e votada em cada Casa do Congresso Nacional, em dois turnos, considerando-se aprovada se obtiver, em ambos, três quintos dos votos dos respectivos membros.

$\S 3^{\circ}$ - A emenda à Constituição será promulgada pelas Mesas da Câmara dos Deputados e do Senado Federal, com o respectivo número de ordem.

$\S 4^{\circ}$ - Não será objeto de deliberação a proposta de emenda tendente a abolir:

I - a forma federativa de Estado;

II - o voto direto, secreto, universal e periódico;

III - a separação dos Poderes;

IV - os direitos e garantias individuais.

(...)
} 
Verifica-se que a nossa constituição indica quais são as matérias sobre as quais não poderá haver deliberação do poder constituinte derivado, que são as chamadas "cláusulas pétreas", previstas no $\S 4^{\circ}$ do art. 60. Essas matérias só poderiam ser discutidas se uma nova constituição fosse elaborada, ou seja, se o poder constituinte originário e sua onipotência criadora voltasse a ser invocado, pois como já mencionamos, esse poder tem como uma de suas característica, a ilimitação.

Recapitulando, estamos discorrendo sobre a justificativa que estaria na base de se afirmar a supremacia da constituição, como no conceito de Dalmo Dallari, que assevera ser a constituição uma "lei que é superior a todas as outras", ou na ênfase de Celso Antônio Bandeira de Mello no sentido de que a constituição “é a Lei Máxima, à qual todas as demais se subordinam". Essa supremacia, conforme apontamos advém de sua origem no poder constituinte originário cuja titularidade é do povo.

Uma das consequiências dessa supremacia é que a constituição não pode ser alterada por meio do sistema pelo qual se elaboram as leis ordinárias; é preciso um procedimento especial. Outra conseqüência, é que todas as demais leis ou atos normativos governamentais devem obediência à constituição.

Para desenvolvermos um pouco melhor essa questão, citemos o conceito de constituição, agora de Luis Roberto Barroso, para quem a constituição

\footnotetext{
Cria ou reconstrói o Estado, organizando o poder político, provendo acerca de direitos fundamentais, valores e fins públicos e disciplinando o modo de produção e os limites de conteúdo das normas que integrarão a ordem jurídica por ela instituída. Como regra geral, terá a forma de um documento escrito e sistemático, cabendo-lhe o papel, decisivo no mundo moderno, de transportar o fenômeno político para o mundo jurídico, convertendo poder em Direito. (2006b, p.145)
}

A força instituidora, atributo do poder constituinte originário, e que dá à constituição um papel fundador da ordem política e jurídica, é mencionada no conceito de Luís Roberto Barroso, uma vez que "cria ou reconstrói o Estado, organizando o poder político".

No conceito do autor, há o destaque para o fato de a constituição disciplinar "o modo de produção e os limites de conteúdo das normas que integrarão a ordem jurídica por ela instituída."

Então, percebe-se que a supremacia da constituição se manifesta também, na indicação dos meios e procedimentos de elaboração legislativa a cargo dos poderes que 
foram instituídos pela constituição. Em nossa constituição temos a descrição de quais são os tipos de normas que podem ser elaboradas (emendas, leis complementares, leis ordinárias, leis delegadas, medidas provisórias, decretos legislativos e resoluções, conforme art. 59), a quem pertence à iniciativa de elaboração de cada espécie normativa e a ritualística geral de processamento (arts. 60 a 69), compondo o que se chama de processo legislativo.

Outro ponto a ser destacado e, que deriva da supremacia da constituição, é que a produção normativa em todas as instâncias legislativas da federação (União, Estados, Distrito Federal e Municípios) está sujeitas a um controle de constitucionalidade, ou seja, se não estiverem em conformidade com as diretrizes da constituição podem ser declaradas inconstitucionais e retiradas do ordenamento jurídico.

E por fim, cabe comentar a situação de países como o Brasil que tiveram em sua história mais de uma constituição, visto que a fundação de uma nova ordem, como na elaboração da Constituição de 1988, por exemplo, leva logicamente à revogação de todas as normas produzidas anteriormente ao seu império. Entretanto, por uma questão de ordem prática, as normas compatíveis com o novo sistema instituído podem ser abrigadas pela nova ordem constitucional pelo instituto denominado "recepção".

Conforme explica Luis Roberto Barroso,

\begin{abstract}
Cronologicamente, de fato, a Constituição é o marco zeros das instituições. Essa afirmativa, todavia, notadamente em um país com a experiência constitucional brasileira, precisa ser confrontada com a circunstância de que, normalmente, já há uma ordem jurídica infraconstitucional preexistente. Por assim ser, criaram-se duas regras pragmáticas para disciplinar as relações entre uma nova Constituição e o Direito que a antecedia: $1^{\text {a }}$ ) todas as normas incompatíveis com a Constituição ficam automaticamente revogadas; $2^{\mathrm{a}}$ ) todas as normas compatíveis com a Constituição são recepcionadas, passando a viger sob um novo fundamento de validade e, eventualmente, com nova interpretação. (2009, p.301)
\end{abstract}

Temos inúmeros exemplos de normas criadas antes da promulgação da constituição de 1988 e que estão em pleno vigor.

Então, em resumo, com base no que expusemos e sem pretensão de sermos exaustivos, destacamos os seguintes aspectos identificadores de uma constituição: sua origem e legitimação provêm da soberania absoluta do poder constituinte originário; é uma manifestação da livre vontade política de um povo; essa vontade se materializa em uma lei superior a todas as outras o que ocasiona a inconstitucionalidade de qualquer ato jurídico que a contrarie; essa lei condiciona a elaboração de todas as outras leis e atos normativos do Poder Público; essa lei, ao contrário das leis em sentido comum, só pode ser alterada 
por um processo legislativo que exige quórum diferenciado (emenda) e há matérias que não podem ser emendadas; essa lei estabelece os fins gerais a serem perseguidos pela nação e está a serviço da dignidade da pessoa humana; essa lei organiza o Estado administrativamente; define os meios de exercício do poder, limita o papel do Estado na esfera econômica; estabelece uma carta de direitos fundamentais.

\subsection{Educação na Constituição}

Não pretendemos, neste tópico, discutir o tratamento ou regime jurídico dado à educação pela Constituição de 1988, ou seja, o direito à educação conforme sua configuração enquanto direito público subjetivo, o financiamento da educação, a forma de repartição de competências entre as esferas da federação, enfim, o temário geral que normalmente é tocado quando se pretende expor a estrutura normativa indicada pela Constituição afeta à educação. É possível encontrar certo número de estudos que fazem esse tipo de percurso. (LIBERATI 2004; MALISKA 2001; MUNIZ 2002; RANIERI 2000)

Destacaremos apenas a natureza social do direito à educação ${ }^{18}$, com um pequeno e despretensioso histórico de sua inserção nas preocupações constitucionais, para então comentar o caráter da norma constitucional instituidora do preparo para o exercício da cidadania, como uma das finalidades da educação em nossa atual Constituição (art.205).

Já comentamos que a noção de constituição foi concebida e modelada originalmente pela ideologia liberal como um instrumento de limitação do poder e garantidora da fruição de direitos individuais e participação política. As preocupações com os direitos sociais foram surgindo no decorrer dos séculos XIX e XX, com o desenvolvimento do Estado de Bem-Estar, em especial em matéria previdenciária, trabalhista e educacional.

Mas o qual seria a diferença, do ponto de vista constitucional, dessa classificação de direitos sociais em relação aos direitos civis e políticos?

\footnotetext{
${ }^{18}$ No capítulo 5 (item 5.4.1), faremos uma breve abordagem política do direito à educação.
} 
Tradicionalmente diz-se que os direitos de liberdade, chamados de "primeira geração $^{19 "}$ são direitos que se dirigem ao Estado para limitá-lo em sua ação na esfera da vida particular do cidadão. Trata-se dos direitos civis (propriedade, liberdade de expressão, liberdade religiosa, etc.) e direitos políticos (participação política). Esses direitos se afirmaram em um contexto de luta contra a opressão de regimes absolutistas nos séculos XVII e XVIII, tendo como documentos culminantes a Declaração de Independência dos Estados Unidos de 1776 e a Declaração Universal dos Direitos do Homem e do Cidadão de 1789. Esses direitos exigiriam do Estado uma abstenção, ou um comportamento negativo em relação aos indivíduos, devendo abster-se de intervir.

Os direitos sociais seriam aqueles que se dirigiriam ao Estado para dele solicitar uma atividade prestacional positiva ${ }^{20}$, já que a garantia desses direitos não é obtida apenas com a abstenção do Estado em interferir na esfera privada do indivíduo, mas justamente o

\footnotetext{
${ }^{19}$ Um trecho da Declaração de Independência Americana, onde se contrapõe os direitos individuais aos desmandos do Poder exercido pelo Rei da Grã-Bretanha nas colônias americanas, será suficiente como exemplo das motivações que culminaram na afirmação histórica da primeira geração de direitos: “(...) Consideramos estas verdades autoevidentes: que todos os homens são criados iguais, dotados pelo seu Criador de certos Direitos inalienáveis, que entre estes estão a Vida, a Liberdade e a busca da Felicidade.Que para assegurar esses direitos, Governos são instituídos entre os Homens, derivando seus justos poderes de consentimento dos governados.-Que, sempre que qualquer forma de Governo se torne destrutiva desses fins, é Direito do Povo alterá-la ou aboli-la, e instituir novo Governo, assentando sua fundação nesses princípios e organizando os seus poderes da forma que lhe pareça mais conveniente para a realização da sua Segurança e Felicidade. A prudência, de fato, dita que os Governos estabelecidos há muito tempo não devem ser mudados por causas superficiais e transitórias; e, assim sendo, toda experiência tem mostrado que a humanidade está mais disposta a sofrer, enquanto os males são suportáveis, do que a se desagravar abolindo as formas a que está acostumada. Mas quando uma longa sequiência de abusos e usurpações, perseguindo invariavelmente o mesmo Objeto, revela o desígnio de reduzir o povo a um Despotismo absoluto, é seu direito, é seu dever, derrubar tal governo, e providenciar novos Guardiões para sua futura segurança.- Tal tem sido a tolerância paciente destas Colônias; e tal é agora a necessidade que as força a alterar os Sistemas anteriores de Governo. A história do presente Rei da Grã-Bretanha é uma história de repetidas injúrias e usurpações, todas tendo por objetivo direto o estabelecimento de uma Tirania absoluta sobre estes Estados (...)

Ele recusou o Assentimento a Leis, as mais salutares e necessárias para o bem público. (...)

Ele convocou os corpos legislativos a se reunir em lugares inusitados, desconfortáveis e distantes dos locais em que se guardam os Arquivos públicos, com o único propósito de fatigá-los até que se submetessem a suas medidas.

Ele dissolveu as Câmaras de Representantes repetidas vezes (...)

Ele tornou os Juízes dependentes apenas da Vontade do soberano quanto à posse dos cargos e ao valor e pagamento dos salários. (...)

Ele manteve entre nós, em tempos de paz, Exércitos Permanentes sem o Consentimento de nossos corpos legislativos. (...) (HUNT, 2009, 219-221)

${ }^{20}$ Uma das diferenças que se costuma apontar entre os direitos civis e políticos em comparação aos direitos sociais, econômicos e culturais é em relação à aplicabilidade. Enquanto os primeiros exigiriam apenas uma posição passiva do Estado e teriam formas de expressão e exigência judicial pouco onerosas, os últimos apresentariam dificuldades maiores de realização prática, uma "justiciabilidade" dificultosa já que as pretensões levadas ao Poder Judiciário visando a sua concretização esbarraria muitas vezes nos custos envolvidos e na impossibilidade de o Poder Público atender a todas as reivindicações, diante de limitações orçamentárias.
} 
contrário, exige a intervenção na ordem econômica, regulação da livre iniciativa, além de investimentos nos setores de seguridade social, saúde, educação, entre outros.

As Constituições consideradas pioneiras no tratamento das questões de natureza social foram, respectivamente, a Constituição Mexicana de 1917 e a Constituição da República Alemã de 1919, conhecida como Constituição de Weimar.

A Constituição Mexicana, sob forte influência anarcossindicalista, foi a primeira a dar aos direitos trabalhistas o status de direitos fundamentais. Além disso, promoveu a expansão do sistema de educação pública, além de conter previsões referentes à reforma agrária e proteção do trabalho assalariado.

Após o desastre da Primeira Guerra Mundial, a Alemanha por meio da Constituição de Weimar de 1919 estrutura um Estado de Democracia Social elevando os direitos trabalhistas e previdenciários à condição de direitos fundamentais e promovendo a proteção à família, à maternidade e com disposições sobre educação pública, inaugurou novos paradigmas para o Ocidente. Note-se na Constituição de Weimar a preocupação com a seguridade social, assunto ausente das preocupações das constituições de cunho exclusivamente liberal: “Art. 161. Para conservação da saúde e capacidade de trabalho, para proteção da maternidade e assistência contra as conseqüências econômicas da velhice, da invalidez e das vicissitudes da vida, o Estado Central (Reich) institui um amplo sistema de seguros, com a colaboração obrigatória dos segurados”. (COMPARATO, 2007, p.198)

No Brasil, a primeira constituição a tratar da temática social e, em especial a sistematizar a educação na esfera constitucional, foi a Carta de 1934.

Nas palavras de Edivaldo Boaventura, "somente com o belo edifício erguido em 1934, começou-se a ter algo mais sistemático sobre educação e direitos sociais na constituição; expressamente nomearam-se os sistemas educativos”. (1996, p.29)

É possível indicar também nas constituições anteriores, a menção ao direito à educação, mas sob um enfoque de direito civil, individualista, tendente a considerar a educação tão somente sob o aspecto de valor na esfera individual e não como componente dinamizador da vida política e social do país.

Assim, por exemplo, a primeira constituição brasileira, a Constituição Imperial de 1824, indica a educação gratuita a todos os cidadãos como uma das garantias civis dos cidadãos (art. 179, XXXII). A educação está nomeada no mesmo conjunto de direitos do qual faz parte a liberdade de opinião, a liberdade de religião, direito de propriedade, entre outros. A educação é um direito individual do cidadão, mas o sentido de cidadão nessa 
constituição é muito peculiar, pois pressupõe a escravidão e com ela um enorme contingente de seres humanos na condição de não-cidadãos.

Diz o art. 149 da Carta de 1934:

\begin{abstract}
A educação é direito de todos e deve ser ministrada pela família e pelos poderes públicos, cumprindo a estes proporcioná-la a brasileiros e estrangeiros domiciliados no país, de modo que possibilite eficientes fatores da vida moral e econômica da nação, e desenvolva num espírito brasileiro a consciência da solidariedade humana.
\end{abstract}

A constituição de 1934 adota pela primeira vez a redação de que a educação é direito de todos, embora a contrapartida "dever do Estado" na fórmula que estamos familiarizados, só viria com a emenda constitucional n¹/69 à Constituição de 1967.

A Constituição de 1988 , em seu art. $6^{021}$ apresenta categoricamente a educação como um direito social. Quanto ao tratamento constitucional geral dado à educação, reproduzimos abaixo uma lista elaborada por Edivaldo Boaventura, relacionando temas ligados à educação que foram tratados na Constituição de 1988 de forma diferenciada em relação às constituições anteriores:

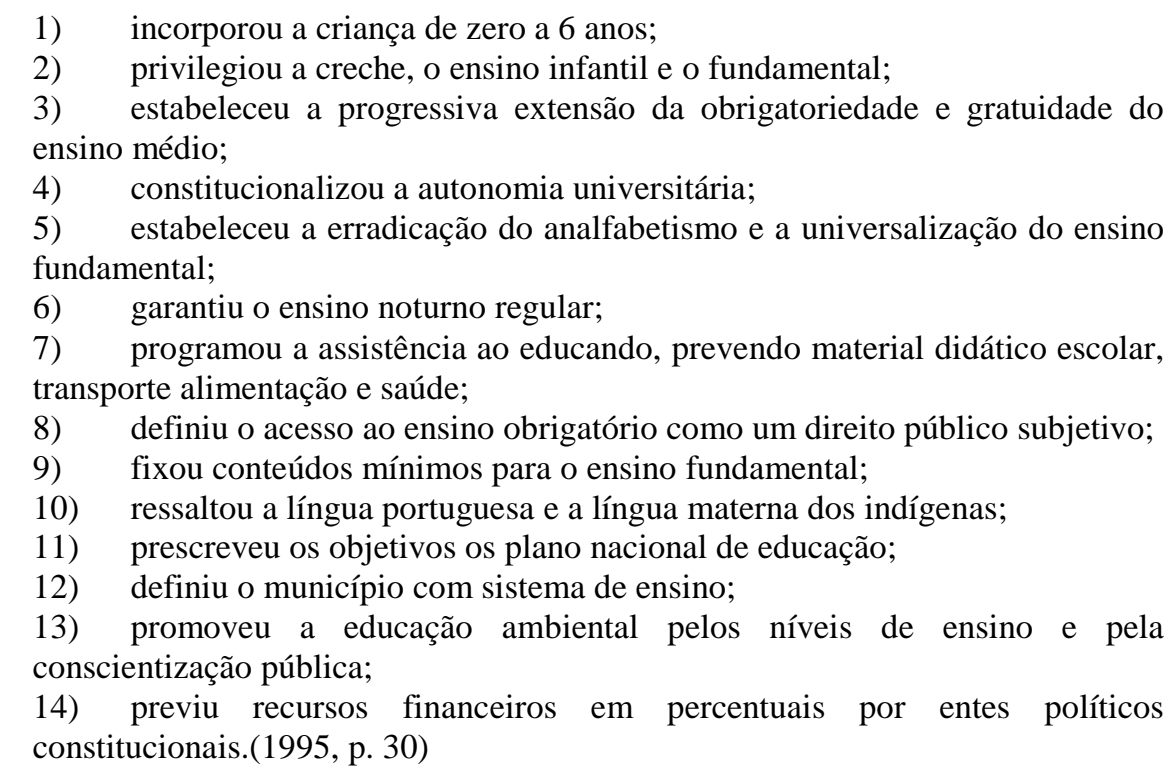

Não é nosso objetivo analisar detalhadamente essas inovações, todas fundamentais e merecedoras, cada qual, de copiosas páginas. Para os nossos objetivos, notamos apenas

\footnotetext{
${ }^{21}$ Art. $6^{\circ}$ São direitos sociais a educação, a saúde, a alimentação, o trabalho, a moradia, o lazer, a segurança, a previdência social, a proteção à maternidade e à infância, a assistência aos desamparados, na forma desta Constituição. (grifo nosso)
} 
que não há nessa listagem, a indicação de que a Constituição de 1988, pela primeira vez na história constitucional brasileira, aponta explicitamente que é finalidade da educação preparar para o exercício da cidadania (art. 205).

A Constituição de 1934, cujo artigo introdutório da temática educacional (art.149) foi citado acima, propõe para a educação um papel que promova "eficientes fatores da vida moral e econômica da nação, e desenvolva num espírito brasileiro a consciência da solidariedade humana." É a única das constituições brasileiras anteriores a 1988, cuja dicção do artigo enunciador do direito à educação, faz menção a finalidades gerais para a educação nacional. Entretanto, essas finalidades são bem mais abstratas do que aquelas indicadas pela constituição de 1988, a saber, pleno desenvolvimento da pessoa humana, preparo para o exercício da cidadania, e qualificação para o trabalho.

As constituições de 1946 e 1967 (mesmo após a emenda nº 1/69) referem-se a ideais inspiradores da educação, como a liberdade, por exemplo, tendo um caráter ainda mais abstrato do que finalidades gerais concebidas nos moldes da Constituição de 1934.

A Constituição de 1946 prevê em seu art. 166: “a Educação é direito de todos e será dada no lar e na escola. Deve inspirar-se nos princípios de liberdade e nos ideais de solidariedade humana."

A Constituição de 1967, art. 168, dispõe que: “a educação é direito de todos e será dada no lar e na escola; assegurada a igualdade de oportunidade, deve inspirar-se no princípio da unidade nacional e nos ideais de liberdade e de solidariedade humana”.

Após a reforma pela Emenda Constitucional (EC) nº 1 de 1969, o art. 176 passou a reger a matéria com a seguinte redação: “A educação, inspirada no princípio da unidade nacional e nos ideais de liberdade e solidariedade humana, é direito de todos e dever do Estado e será dada no lar e na Escola".

A constituição de 1967 ainda não emendada, embora corresponda ao período menos opressor do regime militar, retira a idéia de que a educação deve se inspirar no princípio da liberdade, conforme a Constituição de 1946, mas mantém o ideal de solidariedade e acrescenta a noção de que a educação deve observar o "princípio da unidade nacional", evidenciando as preocupações do regime com aspectos de segurança nacional. Com o endurecimento do regime, e a reforma promovida pela EC $\mathrm{n}^{\mathrm{o}} 1 / 69$, curiosamente a educação volta a ser inspirada também pelo princípio da liberdade.

Portanto, como se vê, a Constituição de 1988 é de fato a primeira constituição brasileira a enunciar a finalidade de educar para o exercício da cidadania, embora não 
tenha sido a primeira a indicar finalidades gerais para a educação, cuja primazia cabe à Constituição de 1934.

Cabe comentar a natureza do artigo 205, enquanto norma constitucional.

Quanto ao caráter das normas constitucionais mobilizadas para o tratamento da temática educacional na Constituição, retomemos a classificação de Luís Roberto Barroso que indicamos no item 1.1.

Podemos dizer que a Constituição de 1988, no tocante à educação, contém os três tipos de normas da mencionada tipologia, ou seja, normas constitucionais de organização, normas constitucionais definidoras de direitos e normas constitucionais programáticas.

Como exemplo de norma de organização, no âmbito da educação, poderíamos citar:

\begin{abstract}
Art. 211. A União, os Estados, o Distrito Federal e os Municípios organizarão em regime de colaboração seus sistemas de ensino.

$\S 1^{\circ}$ A União organizará o sistema federal de ensino e o dos Territórios, financiará as instituições de ensino públicas federais e exercerá, em matéria educacional, função redistributiva e supletiva, de forma a garantir equalização de oportunidades educacionais e padrão mínimo de qualidade do ensino mediante assistência técnica e financeira aos Estados, ao Distrito Federal e aos Municípios; (Redação dada pela Emenda Constitucional no 14, de 1996)

$\S 2^{\circ}$ Os Municípios atuarão prioritariamente no ensino fundamental e na educação infantil. (Redação dada pela Emenda Constitucional no 14, de 1996) $\S 3^{\circ}$ Os Estados e o Distrito Federal atuarão prioritariamente no ensino fundamental e médio. (Incluído pela Emenda Constitucional n ${ }^{\circ} 14$, de 1996)

$\S 4^{\circ} \mathrm{Na}$ organização de seus sistemas de ensino, a União, os Estados, o Distrito Federal e os Municípios definirão formas de colaboração, de modo a assegurar a universalização do ensino obrigatório. (Redação dada pela Emenda Constitucional $n^{\circ} 59$, de 2009)
\end{abstract}

Um exemplar de norma claramente instituidora de direitos seria o art. 208 que estipula: "O dever do Estado com a educação será efetivado mediante a garantia de: (...) § $1^{\circ}$ - O acesso ao ensino obrigatório e gratuito é direito público subjetivo.”

Finalmente, como exemplo de norma programática tem exatamente o art. 205, cujo teor é: "a educação, direito de todos e dever do Estado e da família, será promovida e incentivada com a colaboração da sociedade, visando ao pleno desenvolvimento da pessoa, seu preparo para o exercício da cidadania e sua qualificação para o trabalho."

Como já observamos, uma norma programática veicula os fins gerais perseguidos pelo Estado, evidencia os valores mais prezados por uma comunidade política.

O preparo para o exercício da cidadania como um dos fins da educação está em consonância direta com os próprios fins estabelecidos pelo poder constituinte ao Estado 
brasileiro. Assim, outras normas constitucionais programáticas estipuladas na constituição têm vínculo direito com as finalidades da educação, como por exemplo, o art. $3^{\circ}$ cujo conteúdo é o seguinte: “constituem objetivos fundamentais da República Federativa do Brasil: construir uma sociedade livre, justa e solidária; garantir o desenvolvimento nacional; erradicar a pobreza e a marginalização e reduzir as desigualdades sociais e regionais; promover o bem de todos, sem preconceitos de origem, raça, sexo, cor, idade e quaisquer outras formas de discriminação."

\title{
Maria Helena Diniz esclarece que
}

\begin{abstract}
As normas programáticas são as que o constituinte não regula diretamente os interesses ou direitos nela consagrados, limitando-se a traçar princípios a serem cumpridos pelos Poderes Públicos (Legislativo, Executivo e Judiciário) como programas das respectivas atividades, pretendendo unicamente a consecução dos fins sociais pelo Estado". (1998, p.116)
\end{abstract}

Mas ao contrário do que tradicionalmente se diz sobre as normas programáticas, ou seja, de seu caráter meramente exortativo e destituído de eficácia, pode-se dizer que elas têm eficácia jurídica na medida em que

\footnotetext{
a) impedem que o legislador comum edite normas em sentido oposto ao direito assegurado pelo constituinte (...);

b) impõem um dever político ao órgão com competência normativa;

c) informam a concepção estatal ao indicar suas finalidades sociais e os valores objetivados pela sociedade;

d) condicionam a atividade discricionária da Administração e do Judiciário;

e) servem de diretriz teleológica para a interpretação e a aplicação jurídica (subsunção, integração e correção);

f) estabelecem direitos subjetivos por impedir comportamentos antagônicos a ela. (1998, p.116)
}

Do ponto de vista daqueles que legislam sobre matéria educacional, daqueles que estabelecem currículos e daqueles que atuam diretamente na prática educacional, sejam educadores ou responsáveis administrativos do setor, a finalidade de educar para o exercício da cidadania não é propriamente uma escolha ou uma liberalidade de menor importância, mas antes, reveste-se de indispensabilidade por estar expressa em uma norma constitucional de caráter teleológico, vinculada aos próprios fins do Estado Brasileiro. 


\section{A LINGUAGEM DA EDUCAÇÃO E A LINGUAGEM DA CONSTITUIÇÃO}

Este capítulo pretende abordar a complexidade do conceito de educação, sua amplitude e significados diversos, procurando selecionar os aspectos que a Constituição de 1988 elegeu para regulamentar.

\section{1. “Educação": uma noção}

Uma Constituição, em sua função de oferecer as diretrizes gerais para a organização política e jurídica de um Estado não se detém, normalmente, na tarefa de formular conceitos. Ela se apropria da linguagem cotidiana, de noções advindas dos vocabulários político, jurídico e das diversas áreas de repercussão social sobre as quais legisla e os utiliza sem grandes cerimônias, cabendo ao intérprete dar os seus devidos sentidos.

Há o predomínio de uma linguagem simplificada, conforme explicam Celso Bastos e Carlos Ayres Britto:

(...) a Constituição positiva é vazada em linguagem predominantemente lacônica, não analítica, Â feição uma sinopse de todo o ordenamento normativo. De outra parte, por ser o código primeiro do sistema de direito positivo, regulador das vivências políticas dos cidadãos, ela se patenteia como um estatuto de cidadania ou uma carta de nacionalidade, primando por isto mesmo, pela utilização de palavras e expressões comuns. Vocábulos e locuções de sentido preponderantemente vulgar, extraídos do manancial terminológico do comum do -povo.(BASTOS, BRITTO apud RANGEL, 2008, p. 115)

O texto constitucional se utiliza de uma linguagem comum, já que uma constituição é um documento político, mas por ser igualmente um documento jurídico, também faz o uso de terminologias mais técnicas.

Por exemplo, se tomarmos o inciso LIII, do art. $5^{\circ}$ da Constituição Federal de 1988 que dispõe: "ninguém será processado nem sentenciado senão pela autoridade competente", evidencia-se que a palavra "competente" é um adjetivo com sentido jurídico próprio. Significa que a autoridade que julgará aqueles que se submeterem a processos administrativos ou judiciais (e nesse último caso haverá sentença) será aquela que além de 
estar legalmente nas atribuições do cargo, tem a sua responsabilidade para lidar com o caso advindo das normas de organização processual pertinente.

O inciso XXXVI do art. $5^{\circ}$ da Constituição de 1988 diz que a lei não prejudicará a "coisa julgada", o "direito adquirido" e o "ato jurídico perfeito", noções do universo jurídico, por excelência.

Assim, muitas são as expressões contidas no texto constitucional e cujo entendimento remete ao vocabulário ou jargões típicos do Direito, o que é natural considerando, como já apontamos que a constituição não é apenas um documento político, mas também jurídico.

Outras expressões adquirem um viés jurídico novo, fundado pela própria Constituição, como se o texto constitucional inaugurasse um novo sentido para antigas formas de entendimento. Um exemplo nessa linha seria a noção jurídica de família, que passa a englobar, a partir da Constituição de 1988, a entidade formada por qualquer um dos pais e seus descendentes (art. $226 \S 4^{\circ}$ ).

Mas a Constituição também se utiliza de conceitos portadores de uma carga de significado fora do mundo da prática estritamente jurídica e que possuem uma história complexa e significados múltiplos, em especial quando se trata de normas que se utilizam de noções advindas da Filosofia Política, como democracia, república, cidadania bem como conceitos como saúde, trabalho, meio ambiente, e no caso que nos interessa particularmente, educação.

Educação é uma palavra vinculada a dois vocábulos de origem latina, por meio dos quais se nota a dupla tensão que o conceito mobiliza: de um lado o desenvolvimento de potenciais internos do indivíduo; de outro a impressão de valores e saberes externos a serem incorporados pelo indivíduo na vida em sociedade. No primeiro caso, em que o papel da educação seria guiar um potencial, a evocação etimológica mais apropriada é a do verbo educere, composto pela partícula "e" (ex) que implica em um movimento de dentro para fora e ducere cujo significado principal é conduzir ${ }^{22}$. Há nessa composição, a idéia de que educar é conduzir para fora, fazer aflorar aquilo que de certa forma já existe em potencial no indivíduo. Segundo HIRST e PETERS, “a palavra latina educere normalmente, mas nem sempre, era usada a respeito do desenvolvimento físico." (1972, p.37)

\footnotetext{
${ }^{22}$ Lembramos que a primeira pessoa do singular do verbo "ducere" é "duco" de onde vem o lema da bandeira do município de São Paulo, "non ducor, duco" ("não sou conduzido, conduzo).
} 
No segundo caso, em que há um peso maior na idéia de impressão externa que se dirige ao indivíduo, a evocação etimológica recai sobre o verbo "educare," cujo sentido próprio é amamentação. Lembremos que a palavra aluno (“alumnus"), etimologicamente significa criança de peito, ou lactante. Ou seja, deriva desse sentido "alimentar", uma noção de que educar é um movimento de fora para dentro, uma introjeção de valores e da cultura da comunidade onde o indivíduo está inserido. Segundo HIRST e PETERS, "no latim pós-clássico usava-se "educare" com relação ao cuidado de plantas e animais bem como de crianças." (1972, p.37)

Educação é um conceito por demais amplo, capaz de significar, nas diversas etapas do desenvolvimento de um ser humano, tanto o aprendizado para lidar com necessidades mais básicas da vida nos momentos iniciais da existência quanto o gradual aprendizado das regras sociais complexas de etiqueta, de respeito a normas jurídicas e aos costumes.

Educação pode se referir a um processo formativo de natureza ética, ao desenvolvimento de virtudes cívicas, como também à incorporação de informações e conhecimentos e ao aprendizado de técnicas mais ou menos mecânicas.

Utiliza-se o termo educação tanto para se reportar ao domínio dos cânones culturais de uma civilização por meio de conhecimento escolar sistematizado quanto à dinâmica pedagógica envolvida na convivência em âmbito familiar e social. Ou seja, a noção de educação se reporta a um processo formal escolar institucionalizado, mas também a um processo informal que se faz pelas interações humanas, onde a educação se realiza por meio do convívio, da observação, das instruções gerais recebidas nos desafios da existência e das próprias experiências vitais individuais ou partilhadas.

Quando se reduz à sua expressão escolar, a palavra educação pode ser aplicada ao processo de ensino-aprendizagem ou ao resultado desse processo, sem o qual não teria ocorrido "educação". Essa expectativa de se chegar a resultados pode ser vista em uma perspectiva macro (políticas públicas da área de educação, testes padronizados de larga escala) ou do ponto de vista das interações em uma sala de aula concretamente considerada (avaliações).

$\mathrm{Na}$ linguagem corrente, considera-se um indivíduo como educado ou não, na medida em que pratica ou não os rituais das boas maneiras à mesa, por exemplo; é considerado educado ou não no sentido de conhecer ou não as tradições da comunidade onde vive; é considerado educado ou não no sentido de dialogar ou não com o arcabouço cultural mais amplo que define a civilização na qual está inserido; é considerado educado 
ou não na medida em que demonstre ou não proficiência em determinados conhecimentos constantes de um currículo escolar determinado etc.

Diante de todas essas formas em que é empregada, educação pode ser vista, de maneira ampla, como uma responsabilidade geral de todos, ou seja, da comunidade, dos mais velhos em relação aos mais novos, dos mais experientes em relação aos iniciantes, das famílias, do Estado, dos meios de comunicação de massa etc. Mas também pode ser vista de um ponto de vista restrito, como atribuição de instituições e profissionais especificamente voltados a tarefas educacionais, originando a educação formal ou escolar.

Há inúmeras tentativas de elucidar o conceito de educação, e de forma geral, procura-se nelas conciliar o valor da educação para a realização das potencialidades únicas de cada ser humano e a socialização do indivíduo.

Os dois elementos para que haja educação, segundo Durkheim (2007) são a convivência entre uma geração adulta com uma geração jovem e a ação que a geração mais madura exerce sobre os novos.

Durkheim define educação como "a acção exercida pelas gerações adultas sobre aquelas que ainda não estão maduras para a vida social. Tem por objecto suscitar e desenvolver na criança um certo número de estados físicos, intelectuais e morais que lhe exigem a sociedade política no seu conjunto e o meio ao qual se destina particularmente". (2007, p.53).

A referência seminal para se pensar em educação continua sendo o ideal formativo grego. Werner Jaeger, de forma sintética, diz em sua famosa obra Paidéia: "a essência da educação consiste na modelagem dos indivíduos pela norma da comunidade". (2003, p.15) A modelagem, que evoca a argila e o escultor que artisticamente dá forma à obra de arte é uma metáfora recorrente para dar a noção de formação, do homem.

A educação é uma preocupação política de primeira grandeza, na medida em que envolve a continuidade de uma comunidade organizada, seus valores, sua história, sua língua, sua cultura e, ao mesmo tempo, contribui para a própria renovação dessa comunidade, sua constante reconstrução, seu futuro, afinal, conforme aponta Simone Weil “o futuro não nos traz nada, não nos dá nada; nós é que, para construí-lo devermos dar-lhe nossa própria vida. Mas para dar é preciso ter, e não temos outra vida, outra seiva, a não ser os tesouros herdados do passado e digeridos, assimilados, recriados por nós” (...). (1996, p.418)

Assim, o papel da educação, está vinculado ao recebimento de uma herança entre gerações, como podemos ler nas belas palavras de Michael Oakeshott: 
Todo ser humano nasce herdeiro de um legado que só pode incorporar mediante um processo de aprendizagem. Se essa herança fosse uma extensão territorial, composta de bosques e prados, uma casa de campo em Veneza, ou uma cadeia de lojas, o herdeiro tomaria automaticamente posse dela à morte de seu pai ou chegado à maioridade. (...) Mas a herança de que falo é diferente (...). Todo homem nasce herdeiro de um legado de realizações humanas; uma herança de sentimentos, emoções, imagens, visões, pensamentos, crenças, idéias, compreensões, empresas intelectuais e práticas. Linguagens, relações, organizações, cânones e normas de conduta, procedimentos, rituais, habilidades, obras de arte, livros, composições musicais, ferramentas, artefatos e utensílios (...). E este mundo só pode ser penetrado, possuído e desfrutado por meio de um processo de aprendizagem. Pode-se comprar um quadro, mas não a compreensão que dele se possa ter. E chamo a este mundo nossa herança comum porque penetrá-la constitui a única forma de tornar-se um ser humano, e viver nele é ser um ser humano “(1969, p.245-246)

Por outro lado, considerando a advertência de Walter Benjamin de que "nunca houve um monumento da cultura que não fosse também um monumento da barbárie" (1996, p.225), podemos dizer que a nossa herança também é composta pelas grandes mazelas humanas e suas lições, de forma que, por exemplo, após a $2^{\mathrm{a}}$ Guerra Mundial, diante do saldo absolutamente catastrófico de milhões de mortos produzidos em larga escala como resultado da transposição de todos os limites de desumanidade já imaginados, a educação foi lembrada e destacada pela Declaração Universal dos Direitos Humanos de 1948 como o recurso por meio do qual os povos e nações haveriam de sensibilizar as novas gerações e desenvolver as virtudes necessárias para a não repetição daqueles tenebrosos acontecimentos.

Diz o preâmbulo da Declaração de 1948:

\begin{abstract}
(...)
Considerando que o desprezo e o desrespeito pelos direitos humanos resultaram em atos bárbaros que ultrajaram a consciência da Humanidade e que o advento de um mundo em que os homens gozem de liberdade de palavra, de crença e da liberdade de viverem a salvo do temor e da necessidade foi proclamado como a mais alta aspiração do homem comum,

(...)

A Assembléia Geral proclama

A presente Declaração Universal dos Diretos Humanos como o ideal comum a ser atingido por todos os povos e todas as nações, com o objetivo de que cada indivíduo e cada órgão da sociedade, tendo sempre em mente esta Declaração, se esforce, através do ensino e da educação, por promover o respeito a esses direitos e liberdades, e, pela adoção de medidas progressivas de caráter nacional e internacional, por assegurar o seu reconhecimento e a sua observância universais e efetivos, tanto entre os povos dos próprios Estados-Membros, quanto entre os povos dos territórios sob sua jurisdição. (grifo nosso).
\end{abstract}

Adorno foi categórico a respeito do papel da educação após os horrores perpetrados nos campos de concentração nazistas quando afirma que "qualquer debate acerca de metas 
educacionais carece de significado e importância frente a essa meta: que Auschwitz não se repita”. (2006, p. 119)

É importante não perder de vista o sentido mais profundo da educação diante da diluição de seu valor formativo em favor de um valor de formatura.

Note-se que esse jogo de palavras ( formatura x formação) não é gratuito. Estamos usando a idéia de formatura para designar o aspecto mais utilitário da educação

A palavra formatura remete-nos a um itinerário que chega a um resultado previamente determinado, como uma fabricação. Não é por acaso que o sufixo (t)ura tem como um de seus sentidos, justamente a noção de resultado.(CUNHA, 2000, p.797)

\section{2. "Ensino": uma noção}

"Ensino" também é um termo em uso na Constituição de 1988. O sentido dado pelo texto constitucional será analisado mais adiante, no tópico 2.3.

Ensino significa genericamente transmissão de conhecimentos, não necessariamente em ambiente escolar. Um pai ensina ao filho a fazer pipas; um guarda ensina ao motorista perdido como encontrar a rua procurada; um guia turístico ensina algumas palavras do idioma local aos visitantes etc. O significado etimológico de ensinar, do latim “insignare”, nos dá a imagem de uma marca ou sinal (signo) impresso em um indivíduo.

A noção de educação que vimos no tópico anterior, em função de sua amplitude, pode abarcar a idéia de ensino. Mas quando destacamos do universo de sentidos educacionais gerais o termo "ensino", estamos restringindo o foco para nos reportar a uma atividade composta por um conjunto de procedimentos que visa produzir a aprendizagem.

A discussão qualificada sobre o conceito de "ensino", na verdade, é feita pela Filosofia da Educação.

O filósofo Israel Scheffler oferece a seguinte definição: “o ensino pode ser caracterizado como uma atividade cujo propósito é a realização da aprendizagem, sendo praticado de maneira a respeitar a integridade intelectual do aluno e sua capacidade de fazer juízos independentes” (apud CARVALHO, 2001, p.218) 
Embora haja um propósito, uma intencionalidade nessa atividade, uma das questões importantes na discussão filosófica sobre ensino é o estudo da sua relação com o êxito, ou melhor, a distinção entre as situações em que ensinar implica o êxito em termos de aprendizagem daquelas situações que embora tenha havido ensino, não há garantias de que tenha havido aprendizagem.

Essa dimensão nem sequer vem à baila no uso comum que se faz do termo ensino, muito pelo contrário, há uma naturalização da conexão “ensino-aprendizagem” sendo muito difundido o slogan que diz "não há ensino sem aprendizagem", podendo servir para justificar direta ou indiretamente, a exclusiva responsabilização dos docentes no tocante ao estado de penúria com que se costuma descrever a situação educacional brasileira.

Na verdade, embora ensino implique busca da aprendizagem, essas instâncias são ao mesmo tempo correlatas e autônomas, de forma que é possível haver aprendizagem sem ensino (aprende-se, por exemplo, observando condutas que não estão sendo praticadas com o propósito de ensinar); pode haver aprendizagem apesar do ensino (considerando a sua má condução) e pode haver ensino sem aprendizagem.

\subsection{Educação e Ensino na Constituição de 1988}

Voltando ao problema da terminologia utilizada na constituição de 1988, não há uma conceituação explícita de educação em nosso texto constitucional. A doutrina do Direito Constitucional é que procura apresentar alguma formulação, como, por exemplo, Celso Bastos: "A educação consiste num processo de desenvolvimento do indivíduo que implica a boa formação moral, física, espiritual e intelectual, visando ao seu crescimento integral para um melhor exercício da cidadania e aptidão para o trabalho.” (2000, p. 485)

Mas qual seria o recorte feito pela Constituição, para o tratamento do tema da educação, dada a amplitude de significados possíveis? Nossa tarefa daqui por diante será identificar os sentidos que a educação assume no texto constitucional.

$\mathrm{O}$ art. 205 assevera que "a educação, direito de todos e dever do Estado e da família, será promovida e incentivada com a colaboração da sociedade (...)”. (grifo nosso). Logo em seguida, no art. 206, diz a Constituição:

O ensino será ministrado com base nos seguintes princípios: (grifo nosso) I - igualdade de condições para o acesso e permanência na escola; 


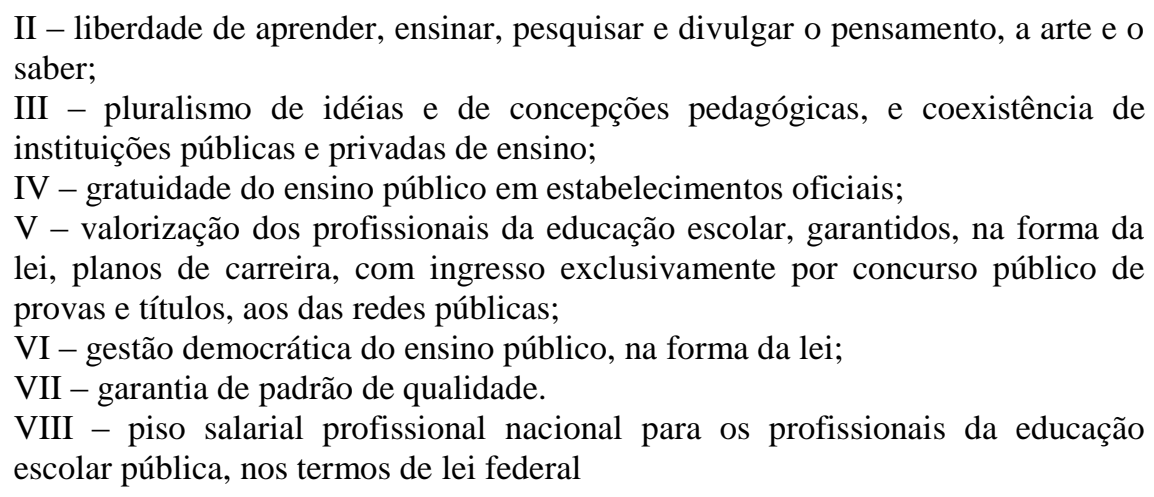

Em princípio, considerando os teores dos arts. 205 e 206, parece que se pode inferir uma diferença constitucional entre o termo amplo "educação", que poderia abarcar inúmeras ações de natureza pedagógica não necessariamente escolares em sentido estrito, e o termo "ensino" que se restringiria à modalidade de educação exclusivamente escolar. Ou seja, educação seria um gênero do qual ensino seria uma espécie.

Note-se que estamos em uma abordagem restrita ao uso desses termos, conforme a Constituição. "Ensino" no universo da Filosofia da Educação gera outras modalidades de discussão, como já observamos.

Assim, o art. 205 enunciaria a educação como um dever do Estado e da família, o que evoca a natureza institucional da educação, já que esse dever implica especialmente a escolarização compulsória ${ }^{23}$, mas também aponta para a colaboração da sociedade, o que remete para um sentido menos institucionalizado de educação. O art. 206 enumera os princípios que devem reger o ensino, ou seja, remeter-se-ia exclusivamente ao universo escolar em sentido estrito.

Entretanto, o uso dos termos "educação" e "ensino" não parecem obedecer a uma clareza distintiva, se observarmos o texto da constituição mais panoramicamente.

No próprio art. 206 fala-se em "ensino público" (inciso VI) e em "educação escolar pública" (inciso VIII).

A Constituição usa o termo "ensino" para nomear o "ensino médio" (art. 208, II), e o "ensino_fundamental" (art. $208 \S 3^{\circ}$ ), mas por outro lado fala em "educação infantill" (art. 208, IV) e "educação básica” (art. 206, parágrafo único).

No texto do Ato das Disposições Constitucionais Transitórias (ADCT), os termos se equivalem, especialmente quando se trata da questão da qualidade. Só a título de

\footnotetext{
${ }^{23}$ Art. $208 \S \S 1^{\circ}, 2^{\circ}$ e $3^{\circ}$ da Constituição Federal de 1988.
} 
exemplo, diz-se "melhoria da qualidade da educação" no art. 60, VI do ADCT e, no mesmo artigo, no $\S 1^{\circ}$, diz-se "melhoria da qualidade de ensino".

Maria Garcia, em breves comentários sobre o uso dos termos "educação" e "ensino" no texto constitucional observa que "a constituição utiliza ora uma palavra'educação'-, ora outra-'ensino'- nas suas disposições, dando a impressão de se tratar de sinônimos". (2009, p.181)

A Constituição, na linha de pensamento expressado pela autora, não se dá conta dos significados distintos que estão abrigados em cada um dos termos e os usa como se fossem sinônimos. Mas embora seja dada essa impressão pelo texto constitucional, a autora enfatiza que há uma diferença terminológica entre eles e exercita uma demarcação do significado de cada um dos termos:

\footnotetext{
"Ensino, segundo o Dicionário Aurélio [1995], é a transmissão de conhecimentos, informações ou esclarecimentos úteis ou indispensáveis à educação.

Educação vem a significar o processo de desenvolvimento da capacidade física, intelectual e moral da criança e do ser humano em geral, visando à sua melhor integração individual e social" (2009, p.181)
}

Mas o que podemos buscar no próprio texto constitucional e que nos auxilie na tentativa de firmar um entendimento sobre o uso dos termos?

Embora seja perceptível essa indistinta permuta dos vocábulos, a própria Constituição aponta para uma distinção de conteúdo, o que indicaria que seriam noções diferentes. Trata-se do art. 24, IX que estipula a competência legislativa concorrente entre União, Estados e Distrito Federal para legislar sobre: educação, cultura, ensino e desporto. (grifos nossos)

O que imaginamos de imediato, é que se foi preciso indicar a possibilidade de legislar-se sobre educação $e$ ensino, é porque são noções que implicariam conteúdos diferentes.

Entretanto, para alguns constitucionalistas, a explicação para o uso de "ensino" e "educação" nesse artigo é um mero defeito da técnica de redação da Constituição, cuja característica marcante seria a repetição de expressões equivalentes, tornando redundantes os discursos.

Nesse sentido, BASTOS e MARTINS dizem que "a ninguém poderia ocorrer que a idéia de que o ensino seja diverso da educação (...). Poder-se-ia legislar sobre ensino, sem 
estar legislando sobre educação? Ou se poderia legislar sobre educação sem, automaticamente, estar-se legislando sobre o ensino? (1993, p.35)

Nas anotações à Constituição de 1988 elaboradas por BARROSO (2006), é interessante indicar que o art. 24, IX apresenta notas de rodapé para as expressões "educação", "cultura" e "desporto", mas o termo "ensino" é ignorado não sendo feita nenhuma observação ou referência legislativa, possivelmente entendendo-se que as observações indicadas para "educação" seriam válidas para "ensino" (na verdade o autor apenas indica ao leitor para se reportar ao art. 205 da Constituição Federal e à Lei de Diretrizes e Bases-Lei 9394/96)

Entretanto, em que pesem essa confusão terminológica e a aparente sinonímia dos termos, parece-nos que podemos retomar aquela distinção que esboçamos mais acima no tocante aos arts. 205 e 206 e nela prosseguir para refiná-la.

$\mathrm{Na}$ verdade, a nosso ver, seria possível identificar dois sentidos básicos para educação no texto constitucional: um sentido de educação amplo, abarcando as ações mais globais que contribuem na formação geral do ser humano e um sentido estritamente escolar que muitas vezes (mas não sempre) recebe o nome de ensino. Portanto, no texto constitucional, o uso do termo "ensino" está sempre atrelado à escolarização formal; já o termo "educação" aparece em alguns dispositivos nesse mesmo significado estritamente escolar e em outros aparece em sentido amplo.

Estamos, portanto, de acordo com Dâmares Ferrreira cujo entendimento sobre a questão dirige-se justamente na percepção de que "educação" foi utilizada na constituição em dois sentidos distintos, embora evidentemente, relacionados: um amplo e outro estrito. Assim, escreve a autora:

O primeiro sentido refere-se a todos os processos de formação humana, enquanto o segundo, somente aos processos desenvolvidos no interior de escolas formais. Este segundo sentido, na verdade, está contido no primeiro, e os conteúdos ministrados por ambos poderão ser até coincidentes. (...)

No primeiro sentido, a educação em sentido amplo abrange genericamente todos os processos formativos que se desenvolvem na vida familiar, na convivência humana, no trabalho, nos movimentos sociais e organizações da sociedade civil, nas manifestações culturais e também nas instituições de ensino e pesquisa; sua promoção é de responsabilidade da família, da sociedade e também do Estado.

Quanto à educação em sentido estrito (art. 208, caput), esta se desenvolve, predominantemente, por meio de transmissão formal do conhecimento em instituições de ensino e pesquisa (...) (FERREIRA, 2004, p.18) 
Não se trata, portanto, propriamente de sinonímia, mas de uma relação entre sentido lato e sentido estrito.

Assim, por exemplo, o art. 208 caput enuncia as garantias por meio das quais será efetivado "o dever do Estado com a educação" e o $\S 1^{\circ}$ do mesmo artigo, estipula que "o acesso ao ensino obrigatório e gratuito é direito público subjetivo". Os termos "educação" e "ensino" estão sendo utilizados, em ambos os dispositivos, no mesmo sentido de educação formal escolar.

$\mathrm{O}$ art. 207, ao tratar da autonomia didático-científica das universidades, diz que elas “obedecerão ao princípio de indissociabilidade entre ensino, pesquisa e extensão." O termo “ensino", evidentemente, está no sentido de educação formal escolarizada em nível superior.

Note-se que no art. 242, $\S 1^{\circ}$, não há nenhuma dúvida sobre o sentido de escolarização dado ao termo "ensino": "o ensino da História do Brasil levará em conta as contribuições das diferentes culturas e etnias para a formação do povo brasileiro".

Agora destaquemos o art. 23, XII que determina: "é competência comum da União, dos Estados, do Distrito Federal e dos Municípios (...) estabelecer e implantar política de educação para a segurança do trânsito."

O sentido de "educação" mobilizado nesse dispositivo não está vinculado necessariamente a entidades escolares, embora no âmbito dessas entidades, programas transversais que levem em conta esse conteúdo possam ter lugar. O que está destacado nesse artigo, na realidade, é o sentido amplo de educação capaz de abarcar ações para além da educação escolarizada, de forma a contemplar, por exemplo, campanhas de esclarecimento cujos destinatários são motoristas e pedestres.

Outro exemplo para analisarmos está no art. 225 que determina:

\footnotetext{
Todos têm direito ao meio ambiente ecologicamente equilibrado, bem de uso comum do povo e essencial à sadia qualidade de vida, impondo-se ao Poder Público e à coletividade o dever de defendê-lo e preservá-lo para as presentes e futuras gerações.

$\S 1^{\circ}$ - Para assegurar a efetividade desse direito, incumbe ao Poder Público: (...)

VI - promover a educação ambiental em todos os níveis de ensino e a conscientização pública para a preservação do meio ambiente;
}

Verifica-se que a "educação" ambiental prevista no artigo se processará em todos os níveis de "ensino", ou seja, deverá receber tratamento pedagógico da educação formal 
escolar, ao mesmo tempo em que será objeto de uma conscientização pública em caráter mais amplo, em uma esfera não escolar.

Em alguns momentos, a Constituição menciona ações educativas em sentido lato sem nenhuma repercussão escolar, a serem exercidos exclusivamente fora do âmbito da educação escolarizada como no capítulo da "Comunicação Social”, art. 221 cujo texto assegura:

\begin{abstract}
A produção e a programação das emissoras de rádio e televisão atenderão aos seguintes princípios:

I- preferência a finalidades educativas, artísticas, culturais e informativas;(...) (grifo nosso).
\end{abstract}

Citamos, ainda, o exemplo do art. $37 \S 1^{\mathrm{o}}$ :

\begin{abstract}
A publicidade dos atos, programas, obras, serviços e campanhas dos órgãos públicos deverá ter caráter educativo, informativo ou de orientação social, dela não podendo constar nomes, símbolos ou imagens que caracterizem promoção pessoal de autoridades ou servidores públicos. (grifo nosso)
\end{abstract}

Assim, o uso da palavra "ensino" na constituição está sempre vinculada ao âmbito escolar; a palavra educação, de acordo com o contexto, poderá significar também escolarização estrita ou poderá ter um sentido amplo sem vínculo necessário com a educação escolar.

Pelo que expusemos, há, portanto, uma justificativa plausível para que o art. 24, IX estipule competência legislativa concorrente entre os membros da federação para legislar sobre educação e ensino. Não se trata de desatenção ou falta de critério dos constituintes ao elaborarem o texto, mas simplesmente o dispositivo contempla dois sentidos de educação: “educação" em sentido amplo e "ensino", no sentido de educação escolar.

De toda sorte, é preciso lembrar que a constituição dá um peso maior, tratamento mais detalhado e rigoroso para a educação escolarizada (que às vezes é denominada de ensino) do que para as outras ações educativas em sentido lato.

Além de apresentar a conformação jurídica geral do ensino em seus diversos níveis, o não oferecimento do ensino obrigatório ou sua oferta irregular, por exemplo, acarreta responsabilização da autoridade competente (art. 208, $\S 2^{\circ}$ ).

É importante ressaltar que o compromisso com a educação formal escolar pública é protegido por outros dispositivos constitucionais. Assim, uma das razões para que ocorra 
intervenção federal da União em um Estado-membro ou no distrito federal é na situação de não “aplicação do mínimo exigido da receita resultante de impostos estaduais, compreendida a proveniente de transferências, na manutenção e desenvolvimento do ensino e nas ações e serviços públicos de saúde" (Art. 34, VII, e). E um Estado não intervirá em seus Municípios, nem a União nos Municípios localizados em Território Federal, exceto quando, entre outros motivos, não tiver sido aplicado o mínimo exigido da receita municipal na manutenção e desenvolvimento do ensino e nas ações e serviços públicos de saúde (art. 35, III).

Edivaldo Boaventura (1992, p. 276-277), citando a obra A Educação na Constituição de 88, de José Augusto Peres, aponta para o fato de a Constituição Federal ter se preocupado, quase que exclusivamente com a educação escolarizada e indica quatro motivos para isso:

- dificuldades de abordagem satisfatória da educação lato sensu;

- preocupação imediata com a escola, instituição mais tangível e mais reclamada;

- intangibilidade de muitos aspectos em que se desdobra a educação mormente a informal; e

- maior importância social, política e econômica da instituição escolar e dos serviços por ela prestados.

De fato, a preocupação da Constituição, em termos de regulação mais minuciosa, está focada na educação escolar, como já apontamos. Entretanto, como também indicamos não se pode dizer que a Constituição se preocupa exclusivamente com essa modalidade de educação.

Cabe comentar, que se a Constituição não indica explicitamente um conceito de educação, a Lei de Diretrizes e Bases (LDB) de 1996 estabelece uma conceituação, logo em seu art. $1^{\circ}$ :

\footnotetext{
A educação abrange os processos formativos que se desenvolvem na vida familiar, na convivência humana, no trabalho, nas instituições de ensino e pesquisa, nos movimentos sociais e organizações da sociedade civil e nas manifestações culturais.
}

Depreende-se que o conceito apresentado é amplo, correspondendo a uma noção de educação compatível com o sentido lato que aparece na Constituição. Mas se continuarmos a analisar o artigo $1^{\circ}$, veremos que o $\S 1^{\circ}$ desse artigo, restringe o sentido quando especifica a dimensão em que a educação será tratada pela LDB: "Esta Lei disciplina a educação 
escolar, que se desenvolve, predominantemente, por meio do ensino, em instituições próprias." $\left(\S 1^{\mathrm{o}}\right.$ do art. $\left.1^{\circ}\right)$.

Como se nota, na LDB, "ensino" é a forma predominante em que se dá a educação escolar. Então, no discurso da LDB, ensino não é sinônimo imediato de educação escolar. É uma das maneiras (a maneira predominante) em que ela se concretiza. Mas note-se que a LDB não oferece uma definição de ensino.

Para os nossos fins, vamos utilizar o termo "educação" no sentido de escolarização. O art. 205, que é o dispositivo com o qual estamos lidando mais reiteradamente, por conter a finalidade constitucional do preparo para o exercício da cidadania, apresenta a educação em sentido geral e amplo visto que recebe a contribuição da família e da sociedade, mas também se apresenta como voltado a regular a escolarização formal.

É possível se falar em preparo para o exercício da cidadania em sentido lato, para se referir ao papel dos partidos políticos, das associações, dos sindicatos etc., como é possível restringi-lo a um sentido escolar. Maria Victoria Benevides, na obra A cidadania ativa, dá um exemplo de educação para a cidadania em sentido lato, quando enaltece o papel da participação política por meio do exercício dos mecanismos de democracia semidireta (referendo, plebiscito e iniciativa popular) como uma prática fundamental para a educação política do povo. Não se trata de um preparo para a cidadania em sentido estritamente escolar, embora a autora se utilize metaforicamente do termo "escola" quando diz que a participação popular por meio dos mecanismos de democracia semidireta poderia ser vista como "uma verdadeira escola de cidadania." (1991, p.196). Trata-se do enaltecimento da prática democrática em seu potencial pedagógico.

No caso da presente dissertação, a referência à educação como "preparo para o exercício da cidadania" está considerando o termo "educação" em sentido escolar; caso outros sentidos sejam mobilizados, eles serão explicitados.

Esse enfoque na educação na modalidade escolar nos leva a esclarecer um pouco melhor sobre quais os níveis de ensino previstos constitucionalmente e detalhados na Lei 9394/96 (Lei de Diretrizes e Bases da Educação- LDB), estamos nos referindo, no tocante ao preparo para o exercício da cidadania. O art. 21 da LDB divide a educação escolar em educação básica (composta por educação infantil, ensino fundamental e ensino médio) e ensino superior. A educação infantil é oferecida em creches para crianças de até três anos e em pré-escolas, para crianças entre quatro e cinco anos. O ensino fundamental tem duração de nove anos, sendo o seu acesso obrigatório às crianças a partir dos seis anos de idade e o ensino médio é a etapa final do ensino básico, com duração de 3 anos. 
Se considerarmos as finalidades da educação prevista no art. 205, "pleno desenvolvimento da pessoa", "preparo para o exercício da cidadania" e "qualificação para o trabalho," e fizermos uma correlação com os níveis de ensino, algumas vinculações não são razoáveis como, por exemplo, imaginar que a educação infantil tem que dar conta de qualificar para o trabalho. A qualificação para o trabalho está mais ligada ao ensino médio profissionalizante e ao ensino superior.

E quanto ao preparo para o exercício da cidadania? Essa finalidade educacional parece estar mais diretamente vinculada ao ensino fundamental e médio, do que aos outros níveis de ensino. O ensino fundamental obrigatório, conforme estabelece a própria legislação educacional, terá como objetivo a formação básica do cidadão (art. 32 da LDB).

$\mathrm{O}$ art. 35 da LDB, que trata do ensino médio, estipula que uma de suas finalidades é “a preparação básica para o trabalho e a cidadania do educando, para continuar aprendendo, de modo a ser capaz de se adaptar com flexibilidade a novas condições de ocupação ou aperfeiçoamento posteriores" (inciso II).

Ainda sobre o ensino médio, o inciso III do art. $36, \S 1^{\circ}$ da LDB, recentemente revogado pela lei 11684/08 dizia que "os conteúdos, as metodologias e as formas de avaliação serão organizados de tal forma que ao final do ensino médio o educando demonstre domínio dos conhecimentos de Filosofia e de Sociologia necessários ao exercício da cidadania". (grifo nosso)

A lei que promoveu a revogação do inciso conforme citado acima, ao mesmo tempo inseriu a obrigatoriedade da Filosofia e da Sociologia como disciplinas obrigatórias no currículo do ensino médio (inciso IV, do art. 36), de forma que essa tônica em "domínio de conhecimentos de Filosofia e Sociologia necessários ao exercício da cidadania" contida no dispositivo revogado, permanece e é ressaltada com a inclusão oficial das disciplinas no currículo.

Diante do que expusemos, podemos concluir afirmando que: a Constituição se utiliza dos termos "educação" e "ensino", embora não apresente as suas definições; há autores que consideram que esses termos são utilizados como sinônimos no texto constitucional, reflexo da falta de precisão na utilização da linguagem, por parte dos constituintes; em nosso ponto de vista, o texto constitucional apresenta a noção de educação em dois sentidos, um sentido amplo, correspondente a um processo de formação com contribuição da família, da sociedade, dos meios de comunicação, do Poder Público em geral e em um sentido restrito, por vezes denominado "ensino," correspondente ao universo da educação 
que tem lugar na instituição escolar; o texto constitucional enfatiza e dá um tratamento mais detalhado para a educação escolarizada em detrimento da educação em sentido amplo; a noção de ensino na constituição não está impregnada com a complexidade que o tema apresenta nos estudos de Filosofia da Educação; o sentido enfatizado por nós nesse estudo no tocante à educação para a cidadania é o de educação escolarizada, em especial de nível fundamental e médio. 


\section{NOÇÃO DE CIDADANIA}

O nosso objetivo nesse capítulo é apresentar um panorama geral, sem a ambição de sermos exaustivos, sobre os diversos aspectos que envolvem a noção de cidadania, mostrar a complexidade que está por trás do aparente consenso no entendimento do termo e indicar uma possível visão a partir da qual se possa pensar em educação para o exercício da cidadania, em conformidade com a Constituição da República.

\subsection{Polissemia ${ }^{24}$ da palavra "cidadania": observações de natureza lingüística}

A primeira grande questão que nos ocorre quando analisamos a finalidade constitucional de preparar para o exercício da cidadania é tentar apontar os problemas de significado que a própria palavra "cidadania" apresenta contemporaneamente, pois se trata de um vocábulo polissêmico.

De qualquer forma, a palavra "cidadania" goza de grande prestígio e respeitabilidade em nosso meio e quando é mencionada, normalmente, é capaz de produzir concordância entre os mais variados matizes ideológicos, claro, desde que não se faça a pergunta: "mas o que é mesmo "cidadania"?

Quando falamos em "cidadania”, normalmente acionamos um universo semântico que, de acordo com o contexto e a ênfase que se queira dar, pode significar: o simples vínculo jurídico de um indivíduo a um Estado-nação assimilado à idéia de nacionalidade; a condição daquele que é titular de direitos políticos podendo participar da vida democrática institucionalizada por meio do voto e outros instrumentos de participação regrados institucionalmente, como a iniciativa popular; condição daquele que tem direitos sociais, econômicos, culturais a serem pleiteados em relação ao Estado, como, por exemplo, o direito à tratamento no sistema público de saúde; a condição daquele que tem deveres em relação ao corpo político do qual faz parte, como por exemplo, fiscalizar o poder público, entre outros sentidos ou nuances possíveis.

\footnotetext{
${ }^{24}$ Polissemia é um termo criado por Michel Bréal na obra "Ensaio de Semântica" de 1897, para marcar o fato de um mesmo significante lingüístico apresentar diversos significados (OLIVEIRA, 2006, p.24)
} 
É prática recorrente em trabalhos que pretendam enfrentar o tema da cidadania, alguma alusão a essa dificuldade de natureza lingüística que cerca o conceito. $\mathrm{Na}$ realidade, só essa questão já ensejaria uma monografia o que não é uma asserção despropositada considerando, por exemplo, o elucidativo trabalho de Sheila Elias de Oliveira (2006) que busca traçar o itinerário de entrada da palavra "cidadania" no vocabulário da Língua Portuguesa e suas mudanças semânticas no tempo, por meio da análise de um corpus composto por representativos dicionários que dão um testemunho da história da nossa língua.

A autora reproduz, no início da obra, a íntegra de um texto do jornalista Roberto Pompeu de Toledo que pretende apresentar o problema do esvaziamento semântico que incide sobre a palavra cidadania. Para os nossos fins, reproduziremos uma parte do referido texto cujo título é "por favor, sem essa de 'cidadania"”:

(...) O oposicionista enche a boca e denuncia o desrespeito à 'cidadania'. O governista estufa o peito e reitera o compromisso com a 'cidadania'. A ONG, do alto de sua neutralidade, convida à adesão A ONG, do alto de sua neutralidade, convida à adesão à causa da "cidadania". É a palavra mais pomposa em circulação no território nacional. Freqüentemente se faz acompanhar de "resgate" -"resgate da cidadania", se diz, e "resgate" é outro caso sério, mas fica para outra oportunidade.

A palavra "cidadania" está em um entre dois temas de redação nos vestibulares: "cidadania e sociedade", "cidadania e educação", "cidadania e...". É sempre cidadania e alguma coisa. Também é muito cotada para título de conferências e seminários. Acharam bonita, caiu no gosto - não do povo, que o gosto do povo é outro, mas daqueles que no tempo de Molière eram chamados de "preciosos" -, e agora? Qual a saída?

Um bom começo seria pedir, a quem a usa, que explique o sentido da palavra. "Cidadania", entre os gregos e os romanos, que inventaram o conceito, era a soma dos direitos dos mais privilegiados - dos nobres, por oposição aos plebeus, dos livres, por oposição aos escravos, dos nacionais, por oposição aos estrangeiros. Com um pouco de licença, mas só um pouco, pode-se concluir que "cidadão" era quem tinha licença para oprimir o outro. Na Revolução Francesa "cidadão" virou forma de as pessoas se tratarem umas às outras, assim como no comunismo se tratarão por "camarada". É um signo de igualdade. No mundo contemporâneo, significa em primeiro lugar nacionalidade, ou seja, cidadão brasileiro é quem pode ter passaporte brasileiro, e em segundo o gozo de direitos políticos, ou seja, votar e ser votado.

Já no sentido precioso de hoje em dia os significados, ao que parece - nunca se sabe bem - se multiplicam. A palavra ainda tem a ver com votar e ser votado, mas também com participação nos negócios públicos. Tem algo com nacionalidade e outro tanto com igualdade, mas também com dignidade, altivez, integridade, respeito aos direitos humanos, atenção ao consumidor, apreço ao 
contribuinte e, talvez mesmo, liberdade. A palavra partiu-se em mil significados, o que equivale dizer que não tem mais nenhum. (...). ${ }^{25}$

Essa descrição, até certo ponto irônica das formas diversas de utilização da palavra cidadania, dá uma visão bastante clara, virtude do texto jornalístico, da sua evidente polissemia e daí podemos inferir as dificuldades para o campo da educação, quando é caso de se pensar sobre o que seria propriamente educar para a cidadania.

Retomando o trecho final do texto, a grande conclusão é que "a palavra partiu-se em mil significados, o que equivale dizer que não tem mais nenhum”. Curiosamente, Jaime Pinsky, que é um estudioso do tema da cidadania sob o prisma da História Social, tem uma percepção diferente, pois acredita que ao contrário da banalização de palavras como revolução que "foi virando qualquer coisa ${ }^{26 "}$, o termo cidadania sofreria não de excesso de significados, mas de um acanhamento de suas possibilidades significativas, limitando-se a expressar, não raro, um sentimento difuso de patriotismo.

Daí porque diz o autor que:

Pode-se (...) esvaziar um conceito por lhe restringir, excessivamente, o significado, não lhe dando a dimensão e a amplitude que tem. É, sem dúvida, o caso de cidadania. Tenho a impressão de que cidadania, para alguns, tem a ver apenas com colocar a mão direita sobre o lado esquerdo do peito enquanto nosso Hino Nacional é executado ou com torcer inutilmente para que algum piloto brasileiro repita os feitos de Ayrton Senna. (2003, p. 18)

Assim, a verdade é que "cidadania", a exemplo do vocábulo "democracia", possui a curiosa virtude de gerar um imediato consenso em sua enunciação e discordâncias quando se começa a esmiuçar melhor o seu sentido. José Mario Pires Azanha (1987), analisando o uso da palavra "democracia" cita um trecho do trabalho de Gerth e Wright Mills (1973, p. 224) no qual os autores dizem que "a palavra democracia, em especial quando usada na moderna competição propagandística, passou, literalmente, a significar todas as coisas para todos os homens". Azanha conclui:

\footnotetext{
${ }^{25}$ O texto está reproduzido integralmente em OLIVEIRA (2006, p. 15-17) e pode ser lido no acervo digital da revista VEJA, acessado por <www.veja.com.br/acervodigital>, ed. 1636 de 16/02/2000, p.146.

${ }^{26}$ Sobre o uso indiscriminado do termo revolução discorre PINSKY com senso de humor :"aqui no Brasil, com nossa proverbial falta de modéstia, tivemos muitas, culminando por chamar o movimento ou golpe de 1964 de revolução (e, às vezes, até com maiúscula!). Sais dez centímetros acima dos joelhos tornaram-se revolução nos costumes; a volta dos pontas disfarçados de laterais era uma revolução no futebol ; televisão na escola tentou ser revolução na educação, e assim por diante.” (2003, p.17)
} 
Esta observação que na sua contundência parece dissuadir qualquer tentativa de clarificação do termo, reflete uma característica da situação histórica que vivemos, na qual o prestígio da posição democrática é tão grande que o termo "democracia" e seus derivados se transformaram em elemento indispensável a qualquer esforço ideológico de persuasão político-social.(1997, p.25)

Pensamos que a análise do autor é totalmente aplicável ao problema de elucidar o conceito de cidadania, pois, em especial após a promulgação da Constituição de 1988, cognominada "cidadã", o termo cidadania, enquanto verniz discursivo, passa a ser mobilizado persuasivamente pelo governo, por políticos das mais variadas tendências ideológicas, por organizações não-governamentais, movimentos de luta por igualdade e respeito no tocante a gênero e diferenças raciais, movimentos de proteção a crianças, idosos, deficientes, além de movimentos ecológicos, entre outros.

Mas o que nós podemos pretender no tratamento dessas dificuldades? Encontrar "a" definição de cidadania para a partir daí forjar "o" modelo de educação para o exercício da cidadania? Evidentemente que não temos essa pretensão. Admitindo a incontornável polissemia do vocábulo, vamos nos limitar a identificar as formas de se perceber "cidadania" mais atinentes às preocupações da Educação, tendo como base o texto da Constituição de 1988.

Ressaltemos que "cidadania" é uma palavra moderna, derivada de citoyenneté, vocábulo francês que remonta a efervescência do período da Revolução Francesa, com o primeiro registro escrito de entrada na língua francesa datado de 1783 . O enunciado definidor da palavra é "qualidade de cidadão.” (OLIVEIRA, 2006, p.79)

A Antigüidade Grega que é para onde nos remetemos quase que automaticamente para a busca dos gérmens da noção que estamos a comentar, não conheceu propriamente a palavra "cidadania", mas apenas a palavra "cidadão" (polites - aquele que está vinculado à polis), de forma que as nossas referências à cidadania na Grécia são construídas, linguisticamente, pela paráfrase "condição de cidadão".

O vocábulo "cidadão" chegou até a Língua Portuguesa via latim, por recepção e adaptação da palavra que designava cidadão entre os romanos (civis - aquele que está vinculado à civitas) formando o vocábulo português "cidadam/cidadão" cujo primeiro registro escrito em língua portuguesa, data de 1269 (século XIII). (OLIVEIRA, 2006, p.39)

Já a palavra "cidadania" tem o seu primeiro registro escrito na Língua Portuguesa em $1913^{27}$, na segunda edição do Dicionário da Língua Portuguesa de Cândido Figueiredo

27 A data também é mencionada no Dicionário Houaiss da Língua Portuguesa (HOUAISS, 2001), ao lado do verbete "cidadania". 
(OLIVEIRA, 2006, p.80), aparecendo dicionarizada como um "neologismo brasileiro", com o significado de "qualidade de cidadão". Dessa forma, para lhe completar o sentido, é necessário recorrer ao verbete "cidadão" que apresenta dois sentidos: "morador de uma cidade" e "aquelle que está no gozo dos direitos civis e políticos de um Estado".

É bastante interessante essa indicação de que a palavra "cidadania" tenha se inserido em uso antes no Brasil que em Portugal. Evidentemente, não temos a intenção de fazer um rastreamento em documentos e publicações da época em busca do uso do termo. Cabe mencionar, apenas que, como é sabido, o vocabulário republicano de matriz francesa $^{28}$ era corrente entre os republicanos brasileiros, embora também tenha concorrido para a formação do imaginário nacional, as fontes americanas, sendo que o modelo de república federativa presidencialista desenvolvido pelos Estados Unidos, marca a própria elaboração da Constituição da "República dos Estados Unidos do Brasil" de 1891, nossa primeira constituição após o fim do Império. Sheila Elias Oliveira conjectura que "podemos supor que o fato de a República ter sido proclamada trinta anos ${ }^{29}$ mais cedo no Brasil do que em Portugal seja uma das razões pelas quais a palavra teria sido introduzida primeiro no Brasil”. (2006, p.80)

Ainda segundo a autora, no decorrer do século XX, nos dicionários brasileiros, há uma constante repetição das relações básicas que permitem definir cidadão: "cidadãomoradia-cidade" e “cidadão-direitos-Estado". (2006, p.84) Essa relação “cidadão-direitosEstado" parece-nos o conjunto de palavras-chave que indicam o universo semântico mais imediatamente acionado quando pensamos em uma noção de cidadania. Nesse tripé, visualizamos o indivíduo, pessoa física, ligado juridicamente a uma coletividade política o que, nas palavras de Ricardo Lobo Torres, "assegura ao homem a sua constelação de direitos e o seu quadro de deveres.” (1999, p.247)

Comentaremos brevemente cada um desses três elementos contidos na noção de cidadania, em sua dimensão lingüística.

Em primeiro lugar, o cidadão. A cidadania é uma prerrogativa da pessoa humana (não da pessoa jurídica), mas não deriva da natureza ou do acaso: trata-se de uma

\footnotetext{
${ }^{28}$ Segundo José Murilo de Carvalho, para a justificação do regime republicano no Brasil, três correntes “disputavam a definição da natureza do novo regime: o liberalismo à americana, o jacobinismo à francesa, e o positivismo. As três correntes combateram-se intensamente nos anos iniciais da República, até a vitória da primeira delas, por volta da virada do século".(2008, p.9)

${ }_{29}$ Na verdade, o fim do regime monárquico em Portugal com a instauração da República, data de 1910. Portanto, o lapso de tempo entre a proclamação da República no Brasil (em 15/11/1889) e em Portugal (05/10/1910), é de quase 21 anos.
} 
construção intencional, uma criação legal. Uma forma possível de entender essa artificialidade é recorrer à teoria da persona, conforme elaborada pelos romanos.

Persona é o nome dado à máscara utilizada pelos atores do teatro clássico, por meio da qual a voz ecoa potencializada, daí a composição lingüística per sonare, ou seja, é um artefato por meio do qual soa a voz do ator. O vocábulo persona, de uso no campo do teatro, metaforicamente, passou a ter sentido também para fins estritamente jurídicos.

Conforme explica Geraldo Ulhôa Cintra,

\begin{abstract}
A máscara jurídica colocada sobre o homem para permitir-lhe agir, no mundo do direito, eis o que é persona, em sentido translato (...) Essa persona pode ser mais ou menos completa; quando é completa, chama-se caput e compreende, então, três status : status libertati, status civitatis e status familiae." (...)O status civitatis é (...) complemento da persona; sem êle a persona não está completa, falta-lhe caput.( 1963, p.75-79)
\end{abstract}

Hannah Arendt aponta-nos a diferença entre um cidadão, ou seja, um homem detentor de uma persona, e um homem dela destituído:

\begin{abstract}
A distinção entre um indivíduo em Roma e um cidadão romano era a de que este último tinha uma persona, uma personalidade legal, como diríamos; era como se a lei lhe tivesse atribuído a parte que se esperava que ele representasse na cena pública, na condição, contudo, de que a sua própria voz pudesse ouvir-se através dela. A questão era que 'não é o Ego natural que entra no tribunal. É uma pessoa com direitos e obrigações, criada por lei, que aparece perante a lei'. Sem a sua persona seria um indivíduo sem direitos e obrigações, talvez um 'homem natural'- isto é, um ser humano ou homo no sentido original da palavra, indicando alguém fora do âmbito da lei e do corpo político dos cidadãos, como, por exemplo, um escravo- mas,decerto, um ser politicamente irrelevante. (2001, p.130)
\end{abstract}

Portanto, a condição de cidadão está vinculada ao pertencimento a um corpo político, ao acesso à cena pública onde a voz, suporte das palavras e dos discursos, pode se ouvida e entendida claramente por todos aqueles que juntos deliberam. Embora esteja se fortalecendo cada vez mais um discurso contemporâneo cosmopolita e desterritorializante, falando-se em uma cidadania mundial em função da globalização econômica e o afrouxamento da soberania dos estados nacionais (VIEIRA, 1998, 2001), a concepção de cidadania continua possuindo laço com um corpo político determinado territorialmente, que corresponde nos dias de hoje ao Estado-nação, mas que no passado correspondeu às cidades-estado. 
No tocante aos "direitos" que estão no cerne da relação entre cidadão e Estado, convém enfatizar que expressam também a contrapartida de deveres, não só do Estado em relação ao cidadão, mas também deste em relação aos outros cidadãos e ao Estado.

Está implícito na enunciação de direitos, que há deveres correlatos. Entretanto, segundo Oliveira, nos dicionários de Língua Portuguesa editados no Brasil a partir do século $\mathrm{XXI}^{30}$, a palavra "cidadania", vai tomando um sentido autônomo em relação à palavra "cidadão" de maneira que, conforme a autora, a diferença de inflexão estaria em "um sentido de dever predicando cidadão ao lado dos direitos, enquanto cidadania é predicada somente por direitos.” (2006, p. 112)

Aparentemente, há uma tendência em se pensar na cidadania enquanto direitos a serem fruídos, esquecendo-se das responsabilidades e deveres implicados, e esse enfoque vai ganhando expressão na língua.

De qualquer forma, deixemos claro que estamos subentendendo que a formulação esquemática de cidadania, mesmo que se refira apenas a "direitos", possui o seguinte contorno: "cidadão-direitos/deveres-Estado".

\subsection{Cidadania em três tempos}

Nos itens seguintes, examinaremos a noção de cidadania considerando três contextos históricos: a antigüidade clássica, a formação do Estado Liberal (final do século XVIII e século XIX) e a formação do Estado Social de bem-estar (século XX).

\subsubsection{Cidadania Antiga}

Nesse esforço que estamos empreendendo para discutir a noção de cidadania, não podemos deixar de fazer uma referência à condição de cidadão conforme sua configuração no contexto da Antigüidade Ocidental, ainda que de forma superficial, sem a pretensão de promover minuciosa análise histórica. Assim, convém fazer breves considerações sobre a condição do cidadão na polis grega e o ineditismo dessa forma de organização, o que ficará

30 Dicionário Houaiss da Língua Portuguesa (HOUAISS, 2001) e Dicionário dos Usos do Português (BORBA, 2002). 
mais evidenciado se apresentarmos brevemente as características da Grécia em momento histórico anterior à configuração da polis, mais especificamente, na época da realeza micênica.

No período de florescimento da civilização micênica, as formas de poder e organização coletiva $^{31}$ estavam baseadas na existência de um poder centralizado em um rei (ánax) e em um corpo administrativo com destaque aos escribas. A escrita era um mecanismo de poder, não só porque inventariava todos os aspectos do reino subsidiando tomadas de decisão da realeza, mas também porque tinha a característica de ser um recurso para iniciados, com poucos a dominar os seus segredos, de forma que a palavra escrita não tinha o papel de divulgação pública, mas tão somente de controle. A estrutura espacial desse modo de organização colocava o palácio real, símbolo de um poder unipessoal, como epicentro da vida coletiva, fazendo as outras construções gravitarem ao redor do palácio.

O surgimento da polis ${ }^{32}$ entre os gregos por volta dos séculos VIII e VII é um acontecimento absolutamente decisivo que marca o início de um novo modo de organizar a vida e as relações entre os homens. (VERNANT, 2009)

O centro da vida coletiva já não é mais o palácio real, reduto da unipessoalidade do poder, e sim a praça pública, a ágora, símbolo de um poder compartilhado entre homens gozando de plena igualdade e é em torno desse espaço público que a vida coletiva se organiza.

A polis, ou o seu universo espiritual segundo Vernant (2009), se caracterizaria por três traços básicos: 1) a superioridade da palavra ou do discurso dialogado sobre todos os instrumentos de poder; 2) a existência de um espaço público de plena visibilidade para assuntos de interesse comum e práticas abertas em oposição a assuntos privados e processos secretos; 3) a igualdade dos cidadãos no exercício do poder.

Em relação ao primeiro traço apontado, a supremacia da palavra, ressalte-se que “todas as questões de interesse geral (...) são agora submetidas à arte da oratória e deverão resolver-se na conclusão de um debate; é preciso, pois, que possam ser formuladas em

\footnotetext{
${ }^{31}$ Conforme esclarece Vernant: "A vida social aparece centralizada em torno do palácio cujo papel é ao mesmo tempo religioso, político, militar, administrativo e econômico. Neste sistema de economia que se denominou palaciana, o rei concentra e unifica em sua pessoa todos os elementos do poder, todos os aspectos da soberania. Por intermédio dos escribas, que forma uma classe profissional fixada na tradição, graças a uma hierarquia complexa de dignitários do palácio e de inspetores reais, ele controla e regulamenta minuciosamente todos os setores da vida econômica, todos os domínios da atividade social.” (2009, p. 24)

${ }^{32}$ Queremos evitar que se pense que estamos a dizer que houve uma passagem imediata da vida palaciana para a estrutura da polis. Evidentemente que há um processo histórico que vai da destruição da vida palaciana pelas invasões dóricas e a configuração da polis. Além disso, consideremos que não houve uniformidade na formação das diversas polis gregas. Para os nossos fins, interessa-nos apenas, de forma bem geral, o efeito do contraste entre esses dois momentos.
} 
discursos, amoldadas às demonstrações antitéticas e às argumentações opostas". (VERNANT, 2009, p. 54)

Aristóteles define o homem como um animal político destacando uma característica muito peculiar dos seres humanos e que os distingue mais claramente dos outros animais: o homem é um animal que faz uso do logos, ou seja, da palavra ou discurso. (Política, 1253a, 1 -20) Evidentemente, o uso da palavra só tem sentido em um ambiente de convivência face a face, onde os discursos sejam relevantes; o uso da palavra, a comunicação por ela proporcionada, a sociabilidade daí decorrente e a política, são dimensões interligadas.

Como diz Hannah Arendt "é o discurso que faz do homem um ser político". (2005, p.11) ou nas palavras de Vernant, "a arte da política é essencialmente exercício da linguagem". (2009, p.54) Isso implica na abdicação da violência como forma de manifestação de vontade política, conforme explica Arendt:

\begin{abstract}
O ser político, o viver numa polis, significava que tudo era decidido mediante palavras e persuasão, e não através de força ou violência. Para os gregos, forçar alguém mediante violência, ordenar ao invés de persuadir, eram modos prépolíticos de lidar com as pessoas, típicos da vida fora da polis, característicos do lar e da vida em família, na qual o chefe da casa imperava com poderes incontestes e despóticos, ou da vida nos impérios bárbaros da Ásia, cujo despotismo era freqüentemente comparado à organização doméstica (2005, p. 35-36)
\end{abstract}

Há também uma reviravolta na função da palavra escrita ${ }^{33}$ que não mais se reduz a um uso limitado às necessidades de controle administrativo e oculta entre as paredes palacianas, mas se destina à ampla publicidade em um papel de veículo de divulgação daquilo que é relevante para a vida comum, já que até a própria língua é patrimônio compartilhado entre todos.

\footnotetext{
${ }^{33}$ Vernant explica que "na queda do império micênico, o sistema palaciano desaba completamente; jamais se erguerá. (...) Abolido o reino do ánax, não se encontra mais traço de um controle organizado pelo rei, de um aparelho administrativo, de uma classe de escribas. A própria escrita desaparece, como desfeita na ruína dos palácios. Quando os gregos a redescobrirem, pelo fim do século IX, tomando-a esta vez dos fenícios, não será somente uma escrita de um tipo diferente, fonética, mas sim o produto de uma civilização radicalmente distinta: não mais a especialidade de uma classe de escribas, mas o elemento de uma cultura comum. Seu significado social e psicológico ter-se-á também transformado- poder-se-ia dizer invertido: a escrita não terá mais por objetivo constituir para uso do rei arquivos no recesso de um palácio; terá correlação doravante com a função de publicidade; vai permitir divulgar, colocar igualmente sob o olhar de todos, os diversos aspectos da vida social e política" ( 2009 , p.38)

Moses Finley lembra que "desde cerca de meados do século V, Atenas adotou a prática de gravar em pedra e expor ao público considerável variedade e grande número de textos oficiais, tratados, leis e decretos, listas de pagamentos de tributos e de homens mortos em combate, etc. Algumas outras cidades faziam o mesmo, embora se deva enfatizar que Atenas era excepcional no que concerne a esse assunto".( 1998, p.25)
} 
Em relação ao segundo traço característico da polis, ou seja, a contraposição entre um espaço público e um espaço privado, esclarece Werner Jaeger que a organização da polis

dá ao homem, ao lado da vida privada, uma espécie de segunda existência,

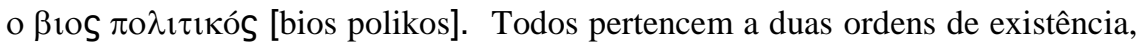

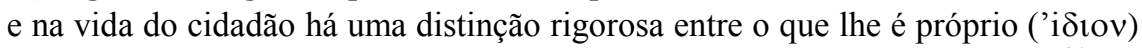
[idion] e que é comum (Kovvov) [koinon]. O homem não é só 'idiota ${ }^{34}$; é 'político' também”. ( 2003, p.144)

O homem, portanto, não seria apenas "idiota" no sentido de alhear-se naquilo que lhe é de interesse privativo, mas também seria político, ao lidar com o que é comum a todos. O privado, em contraposição ao comum, expressa-se na esfera da família ou da casa (oikos).

Note-se a relação intrínseca entre a preeminência da palavra e o âmbito público, lembrando que na esfera privada, ou espaço da casa onde vigora as relações familiares, não é o ambiente para o uso do diálogo e da persuasão, mas onde vigora as ordens ou comandos unilaterais do chefe de família.

Qual a diferença entre essas duas esferas? Poderíamos dizer, inicialmente, que na esfera privada ou da família vigora a falta de liberdade, já que o agrupamento humano se forma para dar conta das necessidades de sobrevivência dos indivíduos ali reunidos (necessidade gerais da espécie humana como alimentar-se, reproduzir-se, etc.). Na esfera privada, os indivíduos estão coagidos pelas necessidades naturais, sendo justificável, nesse contexto, o uso da violência, já que a "violência é o ato pré-político de libertar-se da necessidade da vida para conquistar a liberdade no mundo". (ARENDT, 2005, p.40)

A esfera pública, ao contrário, é justamente a esfera onde vigora a liberdade. Apenas livres das imposições da manutenção da vida é que se torna possível aos homens, a ação política.

O último traço do universo espiritual da polis é a igualdade entre os cidadãos que se reúnem publicamente para discutir as questões de interesse comum.

Vernant explica que "os que compõem a cidade, por mais diferentes que sejam por sua origem, sua classe, sua função, parecem de uma certa maneira 'semelhantes' uns aos

\footnotetext{
34 O prefixo grego idio significa "próprio, pessoal, privativo" (CUNHA, 1997), dando sentido a vocábulos como idioma, idiossincrasia, etc. Finley esclarece que a palavra grega idiotes "significa alguém destreinado, incompetente, ignorante (daí nosso termo 'idiota'), ou, em contextos diferentes, cidadão civil ou militar" (1998, p.29) . No texto de Jaeger, o sentido de "idiota" volta-se para nomear a dedicação aos assuntos privados em contraposição à dedicação aos assuntos públicos .
} 
outros. (...) Todos os que participam do Estado vão definir-se como Hómoioi , semelhantes, depois de maneira mais abstrata, como Isoi , iguais".

Segundo Gilda Naécia Maciel de Barros, a homonoia significava para os gregos a condição de harmonia na polis,

o acordo político das consciências, sobretudo o acordo sobre os fundamentos e os fins do poder, sobre quem ou quais elementos na cidade deviam exercer o governo dela. Não importa que nome tivesse - pode identificar-se uma concórdia que é fruto do governo aristocrático e então o nome dessa ordem é Eunomia, pode identificar-se uma concórdia que é fruto do governo democrático e então o nome dessa ordem é Isonomia; trata-se de ordens muito diferentes, em sua constituição e em seus fins, mas, de qualquer forma, a perturbação da ordem será, sempre, para o grego, Disnomia e o colapso dela, Anomia. (1996, p.53)

O termo grego "isonomia” indicativo de iguais pela lei, marca mais uma diferença entre a esfera pública e a esfera privada, já que é a esfera pública que se abre para a presença daqueles que são iguais, enquanto a esfera privada, o âmbito da casa, é caracterizada por uma intensa desigualdade entre os seus membros, com a presença de comandante e comandados.

$\mathrm{Na}$ verdade, a igualdade é uma construção artificial humana enquanto a desigualdade é a regra da natureza.

Conforme nota Arendt, a isonomia participa da própria configuração da liberdade política na polis, já que "ser livre significava ao mesmo tempo não estar sujeito às necessidades da vida nem ao comando de outro $e$ também não comandar (...) ser livre significava ser isento da desigualdade presente no ato de comandar, e mover-se numa esfera onde não existiam governo nem governados". (2005, p.41-42)

As características da polis que foram indicadas, ou seja, a palavra, a esfera pública demarcada em relação à esfera privada e a igualdade, conformam o surgimento do cidadão (polites) como aquele que participa diretamente no exercício do poder ${ }^{35}$.

Aristóteles esclarece que:

A cidadania não resulta do fato de alguém ter o domicílio em certo lugar, pois os estrangeiros residentes e os escravos também são domiciliados naquele lugar,

\footnotetext{
35 Sobre a questão da participação política entre os antigos, Guarinello esclarece: “quando falamos em participação política na cidade-estado antiga, devemos ter em mente uma diferença radical entre os antigos e nós. Tanto nas oligarquias como nas democracias, a participação política era direta, exercida por um corpo de cidadãos ativos, que podia ser mais ou menos amplo, mas que representava a si mesmo, por meio do voto individual de seus membros. Nunca se desenvolveu a noção de representação, nem partidos políticos doutrinários, nem uma clara divisão de poderes constitucionais ou qualquer noção abstrata de soberania: esta podia residir na assembléia, ou num conselho mais restrito, ou mesmo na lei em geral, dependendo das circunstâncias específicas e do jogo de interesses e forças em conflito". (2008, p. 41)
} 
nem são cidadãos todos aqueles que participam de um mesmo sistema judiciário, assecuratório do direito de defender-se em uma ação uma ação e de levar alguém aos tribunais (este direito cabe também às partes engajadas em um contrato comercial, que também podem acionar e ser acionadas nos tribunais (...) Um cidadão integral pode ser definido por nada mais nem nada menos que pelo direito de administrar justiça e exercer funções públicas(...) (Política, Livro III, capítulo I)

Em uma outra passagem, Aristóteles resume o que é ser cidadão: "aquele que tem o direito de participar da função deliberativa ou da judicial é um cidadão da comunidade na qual ele tem este direito”(...) (Política, Livro III, capítulo I)

Entretanto, Aristóteles reconhece que a sua definição está ligada à cidadania em uma democracia e que o cidadão acompanha a forma em que a cidade é constituída, de tal sorte que há cidades nas quais o povo não é reconhecido como parte da organização política, não podendo participar por meio de assembléias regulares. (Política, Livro III, capítulo I, 1275b)

É preciso ressalvar que a condição de cidadão na polis, mesmo considerando a democracia ateniense, era desfrutada por poucos, bastando destacar no próprio trecho de Aristóteles que citamos acima, a exclusão dos escravos e dos estrangeiros. Os artífices, que em sua maioria seriam escravos e estrangeiros, não deveriam ser admitidos como cidadãos (Política, 1278a). Além disso, as mulheres também são excluídas das deliberações políticas. É representativo que Aristóteles cite o verso de Sófocles que diz "o silêncio dá graça às mulheres" acrescido do comentário "embora isto em nada se aplique ao homem" (Política, 1260b), pois, como já apontamos, a política se faz pelo discurso.

O exercício da cidadania também sofria restrições no tocante à situação econômica do cidadão, embora esse empecilho coincidisse com a condição de escravo ou estrangeiro, conforme lemos na descrição de Richard Sennett:

\footnotetext{
Embora todos os cidadãos, ricos ou pobres, pudessem freqüentar a ágora, a maioria dos eventos cerimoniais e políticos que ali ocorriam eram inacessíveis à imensa população de escravos e estrangeiros - metecos - que sustentavam a economia da cidade antiga. Estima-se que o número de cidadãos da Ática, no século IV a.C., oscilasse entre vinte e trinta mil, para uma população total de 150 a 250 mil. Ao longo da era clássica, eles nunca foram mias do que $15 \%$ a $20 \%$, correspondendo à metade dos homens adultos. Devemos considerar ainda que apenas uns poucos tinham riqueza suficiente para viver sem maiores preocupações, consumindo horas e horas, dia após dia, em conversas e debates; a classe ociosa compunha-se de 5\% a $10 \%$ de todos os cidadãos. Para integrá-la, era preciso possuir uma fortuna de pelos menos um talento, equivalente a seis mil dracmas. O trabalhador especializado ganhava uma dracma por dia. (2006, p. 47)
} 
De toda sorte, com todas as restrições que se possa fazer em relação à prática da cidadania na polis grega, houve ali o nascimento e desenvolvimento de uma experiência absolutamente seminal na história do Ocidente, cuja influência atravessou os séculos e continua a repercutir. A experiência da polis, cuja designação lingüística condiciona a própria constituição da palavra política e também de cidadão (polites), é fundamental para uma idéia de cidadania fortemente marcada pela participação nos assuntos públicos.

Ainda no contexto de pensar a cidadania na Antigüidade, lembremos que a cidadania conforme concebida na polis grega costuma ser citada juntamente com a experiência da cidadania em Roma, sob o manto da expressão geral "cidadania antiga" ou “cidadania greco-romana”, em função de uma espécie de continuidade de concepções políticas.

Entretanto, convém fazermos algumas considerações sobre a cidadania de acordo com a sua configuração em Roma, já que em função do gradual aumento da extensão das conquistas territoriais romanas e da duração do domínio dessa civilização no mundo antigo, não se pode dizer que as características da cidadania romana foram uniformes no tempo e no espaço.

A afinidade com a concepção grega de cidadania está bem caracterizada no período da História de Roma ${ }^{36}$ denominado "Republica". Principalmente nesse período, com a criação de importantes leis ${ }^{37}$ que repercutiam na cidadania e o pleno funcionamento das assembléias que reuniam o povo romano no exercício direto de sua soberania, nota-se uma consonância entre a cidadania romana e a experiência grega, justificando-se a generalização do discurso que aponta uma concepção de cidadania antiga, forjada na Antigüidade greco-romana.

\footnotetext{
${ }^{36}$ A História de Roma costuma ser dividida em 3 grandes momentos que correspondem às formas de governo vigentes: Monarquia (753 a509 a.C.), República (509 a 31 a.C.) e Império (31 a.C a 476 -Império Romano do Ocidente/1453 -Império Romano do Oriente.

${ }^{37}$ Citemos, por exemplo, a Lei Poetélia Papíria (326 a.C.) e a Lei Hortênsia (287 a.C.). A primeira põe fim à servidão por dívida. "Até então, os cidadãos pobres não tinham direito de manter a própria liberdade. Escravizados, ainda que temporariamente, perdiam todos os direitos civis". (FUNARI, 2008, p.54) A segunda permitia que as deliberações da plebe tivessem força de lei, sem a necessidade de ratificação do Senado. (FUNARI, 2008)
} 
Nesse aspecto, considerando um dos textos mais representativos da Antigüidade Romana, a obra "Da República ${ }^{38 "}$ de Cícero, notaremos o destaque dado à dedicação do cidadão aos negócios públicos, seja em um registro grandiloqüente como no trecho em que se lê que "o homem veemente prefere, embora seja chamado de louco e a necessidade não o obrigue, arrostar as tempestades públicas entre suas ondas, até sucumbir decrépito, a viver no ócio prazenteiro e na tranqüilidade” (L1, I), seja em um registro desapaixonado enaltecedor da virtude cívica como no trecho em que diz que 'uma arte qualquer (...) mesmo quando não se pratique, pode ser considerada como ciência; mas a virtude afirmase por completo na prática, e seu melhor uso consiste em governar a República e converter em obras as palavras que se ouvem nas escolas”. (L1, II)

A participação política direta nos negócios públicos, entretanto, exige um contingente de cidadãos pouco numeroso. A própria governabilidade de uma cidade-estado é afetada com grandes contingentes populacionais, conforme observa Aristóteles:

\begin{abstract}
(...) a experiência também mostra que difícil, ou mesmo impossível, governar bem uma cidade muito populosa; ao menos vemos que nenhuma das cidades com reputação de bem governadas permite o crescimento indiscriminado de sua população(...) Há um limite (...) para o tamanho de uma cidade, tanto quanto para o de todas as outras coisas- animais, plantas e instrumentos; nenhum destes reterá a sua forma ínsita se for muito pequeno ou excessivamente grande, mas terá perdido inteiramente sua própria natureza, num caso, e no outro terá degenerado(...) Da mesma forma uma cidade constituída de um número muito pequeno de habitantes não será auto-suficiente (uma cidade deve ser autosuficiente), e uma constituída de um número excessivamente grande, embora auto-suficiente para as necessidades básicas, será um amontoado de gente, e não uma cidade, pois não será fácil dotá-la de um governo constitucional(...) (Política, Livro VII, capítulo IV)
\end{abstract}

Sendo assim, a partir da expansão dos domínios territoriais romanos pelo Mediterrâneo, a comunidade romana ampliou-se de tal maneira que tornou inviáveis as
estruturas políticas comunitárias próprias ao pequeno mundo de uma cidade-
estado. (...) Roma tornou-se uma potência mediterrânica, com extensões para a
Europa central e também o centro de uma sociedade complexa, na qual a
presença de escravos era cada vez mais maciça e perigosa. As estruturas políticas
da antiga cidade-estado de Roma, com suas velhas instituições (magistraturas,

${ }^{38}$ A obra, em forma de diálogo, é inspirada na República de Platão e foi composta entre 54 e 51 a.C. em período conturbado da História de Roma, já nos anos em se anuncia a decadência do período republicano. $\mathrm{O}$ diálogo transcorre no ano de 129 a.C. reunindo nos jardins de Cipião, aos arredores de Roma, figuras históricas relevantes do passado romano em uma discussão sobre a melhor forma de organização política. Os trechos citados pertencem a uma espécie de introdução que Cícero faz antes de iniciar o diálogo propriamente dito, uma vez que, nas palavras do autor "este livro é uma discussão empreendida e seguida por mim a respeito do Estado; e, para não frustrá-la, tive primeiro de combater as dúvidas e desânimos que nos afastam dos negócios públicos”. (L1,VII) 
assembléias, Senado) e seu caráter oligárquico não conseguiam mais dar conta do jogo de pressões e de interesses conflitantes de um espaço tão vasto. Daí as sangrentas guerras civis que agitaram a Itália e o Mediterrâneo até a constituição do Principado, nas décadas finais do século I. a.C., com a vitória do general Augusto sobre seus adversários".(GUARINELLO, 2008, p.43-44)

Com a formação do Império Romano, a vastidão dos domínios territoriais e a incorporação de um contingente populacional inédito, a cidadania vai perdendo a sua característica de participação política e vai se fortalecendo em uma dimensão de proteção jurídica. Os cidadãos passam a ser mais propriamente "súditos" do Império do que participantes ativos no governo.

É paradigmática, nesse sentido, a narrativa de Lucas no livro bíblico Atos dos Apóstolos sobre os acontecimentos ${ }^{39}$ envolvendo a pregação de Paulo de Tarso em Jerusalém, província romana na época. Paulo é hostilizado pela população da região demandando a interferência da guarda romana de tal sorte que

o tribuno ordenou que ele fosse conduzido para o quartel e inquirido com a
flagelação, para saber por que motivo gritavam tanto contra ele. Mas, quando o
ligaram com correias, disse Paulo ao centurião ali presente: É lícito para vós
flagelar um cidadão romano, e sem o ter julgado?" Ouvindo isso, o centurião foi
avisar o tribuno, dizendo-lhe: "Que está para fazer? Esse homem é cidadão
romano!" Vindo então o tribuno ter com ele , perguntou-lhe: “ Dize-me: tu és
romano"? "Sim", respondeu ele. Replicou o tribuno: "Eu adquiri essa cidadania
mediante elevado preço". Paulo retrucou: " Eu, pelo contrário, tal nasci!"
Imediatamente se afastaram dele os que estavam para o flagelar. E também o
tribuno, ao saber que ele era romano, teve medo por tê-lo mandado algemar. (At.22, 24-30)

A cidadania torna-se, portanto, um status legal, havendo uma passagem do zoon politikon aristotélico, que remete ao cidadão envolvido diretamente com as questões do governo da polis, para o homo legalis romano, que remete ao cidadão que gozaria de proteção jurídica concedida pelo soberano. (POCOCK, 1995; CORTINA, 2005)

No ano de 212 , um edito ${ }^{40}$ de Antonino Caracala concedeu a cidadania romana a todos os homens livres do Império, os quais acabaram, na verdade, por se tornar súditos da autoridade suprema do imperador .

Em virtude do que expusemos, é possível dizer que a antiguidade ocidental nos trouxe duas matrizes de cidadania: de um lado, uma cidadania enquanto participação

\footnotetext{
${ }^{39} \mathrm{O}$ episódio todo é narrado em Atos dos Apóstolos 22, 17-30.

40 Segundo Geraldo de Ulhôa Cintra, "o objetivo de Caracala foi político, a unificação do Império; foi religioso, visa aumentar os adoradores dos deuses de Roma; foi fiscal, quer obrigar os peregrinos a pagar impostos nas sucessões; foi social, com vistas a simplificar e facilitar as decisões judiciais. (...) $\mathrm{O}$ edito de 212 é , como ordem legal, a morte da civitas, muito embora não tenha colimado tal fim” (1963, p.54-55)
} 
política exemplificada pela polis grega e a pela república romana; de outro, uma cidadania mais focada na proteção jurídica, desenvolvida no movimento de expansão territorial de Roma cujo ápice se deu no período do Império Romano.

Adela Cortina (2005), com base em Pocock (1995) vê nessas duas matrizes a raiz de duas tradições que se mantém vivas na contemporaneidade: a tradição republicana, "segundo a qual a vida política é o âmbito no qual os homens procuram conjuntamente o seu bem" e a tradição liberal, que "considera a política um meio para poder realizar na vida privada os próprios ideais de felicidade.” (CORTINA, 2005, p.33)

Cada uma dessas tradições corresponderia, em linhas gerais, a um ideal de democracia: o republicanismo privilegiando a participação direta e o liberalismo, a representação política.

De qualquer forma, embora seja possível enxergar na Antigüidade as sementes dessas ênfases diversas na concepção de cidadania, quando se pretende caracterizar a cidadania antiga, normalmente, destaca-se a dimensão da participação política direta e é sob esse enfoque que Benjamin Constant fará a sua famosa conferência comparando a liberdade dos antigos e a dos modernos, texto ao qual faremos referência mais adiante.

\subsubsection{Cidadania Liberal}

Se por um lado as raízes do que entendemos por cidadania encontram-se na Antigüidade greco-romana, de outro lembramos que a própria palavra "cidadania" (citoyenneté) é moderna, estando ligada ao contexto histórico do século XVIII, ao Iluminismo e à Revolução Francesa.

Muito embora a dimensão participativa da cidadania antiga seja destaque na obra de pensadores representativos da modernidade, como Rousseau (exemplo maior nesse sentido), a chamada "cidadania moderna" será calcada, em grande medida, na idéia de proteção jurídica do indivíduo contra o Estado ${ }^{41}$, em função da própria dinâmica de resistência e luta contra o absolutismo monárquico.

A cidadania moderna terá a marca do liberalismo como ideologia política e do individualismo como postura filosófica.

\footnotetext{
${ }^{41}$ Tratamos dessa disposição enquanto inspiradora da própria noção de Constituição, no capítulo 1.
} 
Uma boa síntese da noção de liberalismo e de seu caráter, pelo menos inicialmente, revolucionário e libertário, nos é dada por Paulo Bonavides e Paes de Andrade:

Define-se o liberalismo no plano teórico como uma filosofia de liberdade. Nessa esfera abstrata tem ele uma abrangência sem limites, porquanto, partindo de doutrinas contratualistas, busca pelas vias da razão demonstrar que o homem, titular de direitos naturais, é por essência um ente livre. De tal sorte que a sociedade e o Estado, para legitimarem suas instituições, precisam de aclamar a liberdade, inferida daquele prius, que é denominado status naturalis ou estado de natureza.

Dessa nascente filosófica, o liberalismo partiu para uma vinculação íntima com o pensamento político e social, convertendo-se numa ideologia do poder caracterizado, de início, pelo seu conteúdo revolucionário e vanguardeiro. Tomando dimensão histórica, entrava no reino da realidade para impugnar uma ordem de valores. Pretendia ao mesmo passo remover do plano institucional os abusos do passado, os vícios de poder, os erros da tradição, o prestígio injusto dos privilégios, enfim, suprimir séculos de autoridade pessoal absoluta, de que era expressão concreta e histórica as chamadas monarquias do direito divino. $\mathrm{O}$ Estado liberal, produto acabado do liberalismo e sua ideologia, teve assim uma infância coroada das esperanças de que vinha mesmo para libertar. Os dogmas eram claros e precisos: na ordem econômica, a livre empresa, a livre iniciativa; o laisser faire, laisser passer, a livre trocam a livre competição; na ordem política, o homem-razão, o homem-governante, o homem-cidadão, o homemsujeito, em substituição do subomem ou subser, que fora genericamente aquele súdito e servo das épocas da monarquia e do feudalismo.” (2008, p.102).

A emergência do individualismo ou do valor individual do homem em contraposição a uma concepção orgânica de sociedade onde o todo é mais importante do que as partes, está na base daquela que é chamada por Norberto Bobbio (2004) de a "Era dos Direitos".

Bobbio explica que a "concepção individualista significa que primeiro vem o indivíduo (o indivíduo singular, deve-se observar), que tem valor em si mesmo, e depois vem o Estado, já que o Estado é feito pelo indivíduo e este não é feito pelo Estado" (2004, p.76)

Após indicar que houve, historicamente, a predominância dos deveres ${ }^{42}$ do homem e não de seus direitos, já que a relação entre governantes e governados durante séculos foi

\footnotetext{
${ }^{42}$ Bobbio (2004) cita a predominância, na Antigüidade, de códigos de deveres como os "Dez Mandamentos" e o "Código de Hamurabi".
} 
entendida do ponto de vista dos governantes ${ }^{43}$ (ex parte principis), Bobbio (2004) lembra, evocando Kant, que a centralidade no indivíduo promoveu uma "revolução copernicana" em que o ponto de observação é invertido para permitir um ângulo de visão para aqueles que são governados (ex parte populi).

Talvez, o mais expressivo exemplo da cristalização dessa mudança de perspectiva seja a Declaração Universal dos Direitos do Homem e do Cidadão (1789), que representaria o "atestado de óbito" do Antigo Regime (COMPARATO, 2007) e o "triunfo do Indivíduo" (DUMONT, 1985). Nesse documento temos a explicitação, inspirada principalmente no pensamento de Locke, de que o governo é organizado para proteger os direitos individuais do homem.

Para a nossa discussão sobre a noção de cidadania, convém comentar o próprio título da declaração que se destina a atribuir universalmente direitos ao "homem" $e$ ao “cidadão".

Como interpretar essa divisão homem/cidadão?

José Afonso da Silva afirma que "direitos do homem denota o conjunto dos direitos individuais (...) assinalando à sociedade um fim que é o de servir aos indivíduos, enquanto a expressão Direitos do Cidadão significa o conjunto dos direitos políticos de votar e ser votado, como institutos essenciais à democracia representativa”. (2007b, p. 138-139)

Assim, o documento tem uma pretensão de universalidade inspirando todos os povos a reconhecerem a evidência dos direitos do homem (liberdade, propriedade etc.) que seriam naturais e anteriores à própria organização política estatal; ao mesmo tempo, indica direitos em uma dimensão nacional, ou seja, direitos dos cidadãos franceses (ou de qualquer cidadão de qualquer Estado que se organize com base nesses direitos), afinal, como diz o art. $2^{\circ}$ da Declaração, "a finalidade de toda associação política é a conservação dos direitos naturais e imprescritíveis do homem".

A declaração se vale de uma noção abstrata de "homem", que não dependeria de raça, sexo, posição social ou nacionalidade para ser titular de direitos, mas também se

\footnotetext{
${ }^{43}$ Segundo Bobbio houve, na história a predominância do ponto de vista dos governantes uma vez que“o objeto da política foi sempre o governo, o bom governo ou o mau governo, ou como se conquista o poder e como ele é exercido, quais são as funções dos magistrados, quais são os poderes atribuídos ao governo e como se distinguem e interagem entre si, como se fazem as leis e como se faz para que sejam respeitadas, como se declaram guerras e se pactua a paz, como se nomeiam os ministros e embaixadores. (...) Ao tema do poder de comando, corresponde -do outro lado da relação -o tema da obrigação política, que é precisamente a obrigação, considerada primária para o cidadão, de observar as leis. Se reconhece um sujeito ativo nessa relação, ele não é o indivíduo singular com seus direitos originários, válidos também contra o poder de governo, mas é o povo em sua totalidade, na qual o indivíduo singular desaparece enquanto sujeito de direitos". (2004, p.74-75)
} 
utiliza do termo "cidadão" para veicular a idéia do homem em situação política concreta, ou melhor dizendo, o indivíduo vinculado a uma organização política estatal.

Em meio a uma gramática de direitos em uma Era de Direitos, a cidadania moderna tem um aspecto de proteção do indivíduo que se expressa sob a forma de direitos civis e também um aspecto de participação nos negócios públicos que se expressa sob a forma de direitos políticos, embora a versão moderna de participação seja bem mais limitada, estruturada em um sistema representativo.

Mas o caráter aparentemente amplo, generoso e inclusivo da cidadania em sua configuração liberal, fica melhor delineado em suas intenções, na realidade mais restritivas, se atentarmos para a elucidação que nos oferece Sieyès, autor já por nós citado no capítulo 1 , quando mencionamos a teoria do poder constituinte. Sieyès distinguia, de um lado, os direitos naturais e civis dos cidadãos e de outro os seus direitos políticos:

\begin{abstract}
A diferença entre esses dois tipos de direitos consiste em que os direitos naturais e civis são aqueles para a manutenção e o desenvolvimento dos que formam a sociedade; e os direitos políticos aqueles através dos quais a sociedade se forma. Parece melhor, para a clareza da linguagem, chamar os primeiros de direitos passivos e, os segundos, direitos ativos.

Todos os habitantes de um país devem gozar dos direitos do cidadão passivo: todos têm direito à proteção de sua pessoa, de sua propriedade, de sua liberdade etc; mas nem todos têm direito de tomar parte ativa na formação dos poderes públicos; nem todos são cidadãos ativos. As mulheres, ao menos no Estado atual, as crianças, os estrangeiros, aqueles, ainda, que não contribuam em nada para o sustento da instituição pública, não devem influir ativamente sobre a coisa pública. Todos podem gozar das vantagens da sociedade, mas somente aqueles que contribuem para a instituição pública são os verdadeiros acionários da grande empresa social. Somente eles são os verdadeiros cidadãos ativos, os verdadeiros membros da associação. (2008, p. 69)
\end{abstract}

A Constituição francesa de 1791 acolheu essa distinção que serviu de modelo para vários países que elaboraram as suas constituições no século XIX (COMPARATO, 1993), inclusive para Brasil Imperial quando da elaboração da Constituição de 1824, conforme veremos quando comentarmos os aspectos jurídicos da cidadania.

Essa participação política que exclui, entre outros, aqueles que não pagavam tributos e as mulheres, ainda podia ser limitada, notadamente, por critérios censitários e de grau de instrução, de forma que o termo genérico "cidadão", aplicável, em princípio, de forma ampla aos indivíduos vinculados a um Estado-nação, na verdade, guarda em si uma subdivisão em dois tipos de cidadãos: um cidadão pleno chamado "cidadão ativo" que além de ser titular de direitos civis garantidos juridicamente, também possui direitos políticos, e um "cidadão passivo" (na verdade incompleto), sem direitos políticos. 
No tocante ao aspecto político, há, na verdade, uma certa hostilidade da burguesia, como classe social dominante, pelo menos nos momentos iniciais de formação do Estado Liberal, em relação à participação política dos estratos inferiores social e economicamente.

Domenico Losurdo (2004), em sua análise da história do pensamento liberal no tocante ao sufrágio universal, recolhe exemplos de autores e aponta exemplos históricos que demonstram repúdio à participação política de trabalhadores sob justificativa principal de que aqueles que precisam trabalhar não teriam tempo e nem preparo para se dedicar às questões políticas.

Diz Benjamin Constant, por exemplo, que "aqueles que a indigência mantém numa eterna dependência e condena aos trabalhos diários" não se mostram "mais iluminados do que as crianças quanto aos negócios públicos”. (apud LOSURDO, 2004, p.34) Walter Bagehot questiona o uso que poderia ser feito dos direitos políticos pela massa que "não tem tempo para melhorar a si mesma porque deve trabalhar o dia todo". (apud LOSURDO, 2004, p. 68)

Como se sabe, nos momentos iniciais da Revolução Francesa, com base principalmente no pensamento político de Rousseau, houve no movimento uma reminiscência de padrões de participação política evocados da Antigüidade, conformando concepções políticas que exigiriam a presença mais efetiva do cidadão na condução dos negócios públicos.

A conhecida conferência proferida por Benjamin Constant em 1819 e que gerou o texto "Da liberdade dos antigos comparada à dos modernos" visava demonstrar a inadequação de se pensar a participação política dos cidadãos modernos nos mesmos moldes que ocorria na antigüidade greco-romana. Aqui temos o paradigma mais bem delineado da forma liberal de se conceber a participação política.

Em seu texto clássico, Constant concebe a liberdade antiga greco-romana como aquela que "se compunha da participação ativa e constante do poder coletivo. (1985, p. 15)

Portanto, a liberdade política para os antigos teria uma relação mais apropriada com deveres do cidadão para com a comunidade do que com direitos dos indivíduos em face da organização política.

Segundo Constant, as instituições inspiradas nas formas antigas, tendentes a uma preponderância do interesse da coletividade e a uma liberdade que implica participação ativa nos negócios públicos, não seriam compatíveis com o espírito da modernidade por 
impedirem o florescimento da liberdade individual como a ausência de interferência na vida privada, que seria a primeira das necessidades modernas. (1985, p. 19)

Essa não interferência na vida particular dos indivíduos corresponderia ao cerne da concepção liberal de liberdade. Tal liberdade garantiria aos indivíduos a não interferência do Estado em suas vidas particulares, permitindo-lhes o desfrute dos direitos individuais, como a propriedade, por exemplo, o que coincide com os interesses da classe burguesa no desenvolvimento das potencialidades empreendedoras da livre iniciativa nas modernas sociedades comerciais e industriais.

O contraste pode ser notado mediante um pequeno trecho de Cícero, representando a preponderância do coletivo sobre o interesse particular, marca da República Romana:

\footnotetext{
A pátria não nos gerou nem educou sem esperança de recompensa de nossa parte, e só para nossa comodidade e para procurar retiro pacífico para a nossa incúria e lugar tranqüilo para o nosso ócio, mas para aproveitar, em sua própria utilidade, as mais numerosas e melhores faculdades das nossas almas, do nosso engenho, deixando somente o que a ela possa sobrar para nosso uso privado. ( $D a$ República, L1, IV)
}

Em função das ocupações de ordem econômica dos modernos, que não contariam como os antigos com o instituto da escravidão para liberá-los do império da necessidade, e também pelas condições mais complexas de organização do Estado-nação moderno, no lugar de uma concepção de participação política direta do cidadão privilegia-se a representação política. O homem moderno precisaria de todo o tempo disponível para dedicar-se aos seus negócios particulares, de forma que as questões de interesse público podem ser delegadas a representantes indicados por meio do voto.

Em suma, a cidadania liberal, em sua forma clássica, concebe o cidadão em dois sentidos básicos: o cidadão passivo, como aquele que é titular de direitos civis e deve ser protegido da ingerência do Estado em sua vida privada, e o cidadão ativo, que além dessas garantias, é titular de uma participação política mediada pelo sistema representativo.

\subsubsection{Cidadania sob a égide do Estado Social de Bem Estar}

Como vimos, a concepção liberal clássica de cidadania pressupõe que o Estado restrinja-se à função de proteção dos direitos civis, sem interferência na liberdade do indivíduo (livre iniciativa, liberdade de contratar, etc.) e que os direitos políticos sejam 
mediados pela representação. Os titulares plenos desse conjunto de direitos, no Estado Liberal em suas origens, são os chamados cidadãos ativos, oriundos das classes favorecidas economicamente.

Mas o que significariam os direitos civis e políticos para a população dos extratos inferiores social e economicamente?

$\mathrm{Na}$ verdade, a aclamação de que todos são iguais perante a lei, teve em sua generosidade universal, um compromisso muito mais próximo com o interesse da burguesia em atacar os privilégios hereditários do Antigo Regime do que com a busca de uma igualdade que envolvesse também os despossuídos dentro da noção de cidadania. É fato que a condição de servo é substituída pela condição de cidadão, no sentido de titularidade de direitos civis, e o sistema de proteções que as classes desfavorecidas gozavam na Idade Média vai sendo substituído pela igualdade de todos em fruir da liberdade de, por exemplo, vincular-se por meio de um contrato de trabalho. Entretanto, conforme analisa Reinhard Bendix o

\begin{abstract}
(...) ganho de igualdade legal subsiste ao lado da desigualdade social e econômica. Tocqueville e outros apontam que na sociedade medieval, muitas pessoas dependentes eram protegidas de alguma maneira contra as dificuldades da vida pelo costume e pela benevolência paternal, embora às custas da subserviência pessoal. A nova liberdade do contrato salarial destruiu rapidamente toda e qualquer proteção desse tipo que existia anteriormente. Pelo menos durante algum tempo, nenhuma nova proteção foi instituída no lugar das antigas; conseqüentemente, o preconceito de classe $\mathrm{e}$ as desigualdades econômicas prontamente excluem a grande maioria da classe baixa do gozo de seus direitos legais. O direito do indivíduo de afirmar e defender suas liberdades civis básicas em termos de igualdade com os outros e pelo devido processo legal é formal, no sentido de que os poderes legais estão garantidos, na ausência de qualquer tentativa de assistir o indivíduo em seu uso de poderes." ( 1996, p.112)
\end{abstract}

A estrutura de desigualdade social em relação à qual o capitalismo é indiferente, principalmente em seus momentos iniciais, é de problemática compatibilização com a idéia de igualdade que emerge da noção de cidadania.

Essa situação só pôde ser melhor equacionada com a formação do Estado de bem estar social e a entrada dos direitos sociais como conteúdo da cidadania, no século XX. Uma das teorias mais influentes para conceber a cidadania sob o impacto dos direitos sociais é descrita no texto seminal do sociólogo T.H. Marshall, Cidadania, Classe e Status $^{44}$. O diálogo com esse texto, a sua tomada como ponto de partida parece ser

${ }^{44}$ Trata-se, mais especificamente, do capítulo 3 da referida obra, denominado "Cidadania e Classe Social". Na verdade, o texto de T.H. Marshall é a transcrição de conferências proferidas em 1949 e dedicadas ao economista Alfred Marshall, que havia tratado do tema geral da igualdade social no "The future of working 
praticamente obrigatório em grande parte da bibliografia sobre cidadania tanto na área das ciências sociais como no campo jurídico.

A obra é escrita no período do pós-guerra, em um contexto de afrouxamento do dogma liberal clássico da não interferência do Estado na economia e o concomitante alargamento do seu papel, com uma presença mais ativa como regulador da atividade econômica propiciando uma ampliação do espectro de proteção estatal.

Como esclarece o autor, ao se referir às intenções de seu texto, "meu objetivo principal é a cidadania, e meu interesse especial consiste em seu impacto sobre a desigualdade social”. (MARSHALL, 1967, p. 75)

Marshall analisa a tensão existente entre "classe social", que é um instituto de desigualdade e a "cidadania", cujo objetivo seria promover a igualdade:

A cidadania tem sido uma instituição em desenvolvimento na Inglaterra pelo menos desde a segunda metade do século XVII, então é claro que seu crescimento coincide com o desenvolvimento do capitalismo, que é o sistema não de igualdade, mas de desigualdade. (...) não há dúvida de que, no século $\mathrm{XX}$, a cidadania e o sistema de classe capitalista estão em guerra ${ }^{45}$. $(1967$, p. 76$)$

O autor aponta o paulatino alargamento do sentido de cidadania por meio do processo de incorporação de direitos ao acervo do cidadão (direitos civis, direitos políticos e direitos sociais), tomando como base a História da Inglaterra a partir do século XVIII.

Marshall explica o que entende por cada uma dessas esferas de direitos da seguinte forma:

O elemento civil é composto dos direitos necessários à liberdade individual-
liberdade de ir e vir, liberdade de imprensa, pensamento e fé, o direito à
propriedade e de concluir contratos válidos e o direito à justiça. Este último
difere dos outros porque é o direito de defender e afirmar todos os direitos em
termos de igualdade com os outros e pelo devido encaminhamento processual.
Isto nos mostra que as instituições mais intimamente associadas com os direitos
civis são os tribunais de justiça. Por elemento político se deve entender o direito
de participar no exercício do poder político, como um membro de um organismo
investido da autoridade política ou como um eleitor dos membros de tal
organismo. As instituições correspondentes são o parlamento e conselhos do
Governo local. O elemento social se refere a tudo o que vai desde o direito a um
mínimo bem-estar econômico e segurança ao direito de participar, por completo,
na herança social e levar a vida de um ser civilizado de acordo com os padrões

classes" sob o prisma do custo econômico. T.H. Marshall se propõe a retomar as preocupações de Alfred Marshall, agora sob um viés sociológico.

45 Em um outro momento do texto, o autor refere-se a essa "guerra" da seguinte forma: "afirmei, anteriormente, que a cidadania e o sistema de classes capitalista têm estado em guerra no século XX. Talvez a frase seja um tanto exagerada, mas não há dúvida de que a cidadania impôs modificações no referido sistema de classes”.(MARSHALL, 1967, p. 103) 
que prevalecem na sociedade. As instituições mais intimamente ligadas com ele são o sistema educacional e os serviços sociais". (1967, p.63-64)

Segundo Marshall, a cidadania seguiu, pelo menos no caso inglês, uma espécie de itinerário cronológico que passaria pela conquista dos direitos civis no século XVIII, direitos políticos no século XIX e direitos sociais no século XX.

Como indicamos, o objetivo principal do autor seria analisar a influência que a cidadania teria tido sobre a desigualdade social. Ora, o impacto dos direitos civis e posteriormente o impacto dos direitos políticos, não tiveram o poder de reduzir a desigualdade social substancialmente, segundo a análise do autor.

Os direitos civis, que comporiam o núcleo da cidadania no século XVIII, sendo indispensáveis para a liberdade competitiva de mercado, "não estavam em conflito com as desigualdades da sociedade capitalista; eram ao contrário necessários para a manutenção daquela determinada forma de desigualdade”. (MARSHALL, 1967, p. 79)

Marshall exemplifica as desigualdades implícitas em um modelo de cidadania que não contempla direitos sociais, por meio do significado do direito à propriedade e da liberdade de expressão para as classes desfavorecidas:

\footnotetext{
Um direito de propriedade não é um direito de possuir propriedade, mas um direito de adquiri-la, caso possível, e de protegê-la, se se puder obtê-la. Mas, caso se lance mão desses argumentos para explicar a um pobre que seus direitos de propriedade são os mesmos daqueles de um milionário, provavelmente o indigente nos acusará de estar sofismando. Da mesma maneira, o direito à liberdade de palavra possui pouca substância se, devido à falta de educação, não se tem nada a dizer que vale a pena ser dito, e nenhum meio de se fazer ouvir se há algo a dizer, mas essas desigualdades gritantes não são devidas as falhas nos direitos civis, mas à falta de direitos sociais, e os direitos sociais, nos meados do século XIX, não tinham expressão. (1967, p.80)
}

No tocante aos direitos políticos, a desigualdade se expressava não só pela intimidação das classes subalternas no tocante ao livre exercício do voto, como também pelo monopólio de classe da própria atividade política.

Entre o direito e o remédio jurídico que poderia garanti-lo havia impedimentos, ou barreiras que seriam de duas espécies: a barreira dos preconceitos de classe e a barreira da desigual distribuição de renda. (MARSHALL, 1967)

Dessa forma, de fato, os direitos civis e direitos políticos, embora fundamentais no desenvolvimento da cidadania, tiveram "pouca influência direta sobre a desigualdade social”. (MARSHALL, 1967, p. 87) 
O aprimoramento da cidadania em direção de maior igualdade (lembremos que a análise de Marshall é focada na sociedade inglesa) só foi possível em um processo lento de superação das duas barreiras acima apontadas, que culminaria, no século XX, com a configuração do Estado de bem estar e a garantia de uma série de direitos sociais.

É evidente que o autor não defende um regime igualitário que afaste todas as desigualdades geradas pelo sistema de livre mercado; é uma análise de matriz liberal que mantém as bases do capitalismo, mas com ajustes que compatibilizariam a desigualdade sócio-econômica com a igualdade advinda do status de cidadania, garantindo-se, ao menos, condições mínimas abaixo das quais a desigualdade seria intolerável, conforme podemos inferir lendo a seguinte passagem do texto de Marshall:

\footnotetext{
O Estado garante um mínimo de certos bens e serviços essenciais (tais como assistência médica, moradia, educação, ou uma renda nominal mínima (ou salário mínimo) a ser gasto em bens e serviços essenciais- como no caso da lei que dispõe sobre aposentadoria por velhice, benefícios de seguro e saláriosfamília. Qualquer pessoa capaz de ultrapassar o mínimo garantido por suas qualidades próprias está livre para fazê-lo (...) (Marshall, 1967, p. 93)
}

O esquema explicativo "evolucionista" de Marshall, que indica o surgimento dos direitos civis, políticos e sociais em séculos sucessivos, baseia-se em um exemplo localizado e dificilmente universalizável, pois leva em conta as condições de desenvolvimento da cidadania específicas da Inglaterra. Entretanto, a teoria de Marshall costuma ser utilizada como uma espécie de modelo teórico "ideal" de formação do conceito de cidadania, de grande influência a partir da segunda metade do século XX.

As versões contemporâneas de cidadania partem das concepções que indicamos, panoramicamente, nos itens anteriores, enfocando-se ora a participação política, ora a garantia de direitos. Essa garantia de direitos pode ser ampla, com base na lição de Marshall, ou restrita, em visões que se apóiam no liberalismo mais ortodoxo, como na onda neoliberal de grande influência nas últimas décadas.

Parece que a dicotomia status legal (proteção jurídica) x participação política é uma dicotomia representativa no entendimento da noção de cidadania e há várias formas de se referir a ela. Will Kymlicka e Wayne Norman (1995), por exemplo, usam o termo "fino" (thin) para se referirem à cidadania como status legal daquele que é membro de uma comunidade política e goza de direitos e o termo "espesso" (thick) para indicarem a noção de cidadania como participação na comunidade política. 
George Armstrong Kelly, segundo nos mostra Fábio Wanderley Reis, propõe algo semelhante distinguindo uma dimensão "cívica" e uma dimensão "civil" da cidadania:

Kelly compara as dimensões cívica e civil de cidadania. Do seu ponto de vista, a dimensão cívica está ligada a deveres e responsabilidades de cidadãosespecificamente, à propensão dos últimos a formas solidárias de comportamento e à observância de virtudes cívicas. Esta dimensão cívica envolve um processo de identificação com a coletividade, ou com uma concepção de identidade pessoal profundamente marcada pela inserção do indivíduo dentro da comunidade. O caso mais avançado de cidadania cívica é o da polis grega, mas o Estado-nação moderno também busca mobilizar tais sentimentos e atitudes da parte de seus membros. Ao contrário, a dimensão civil de cidadania corresponde à busca moderna por afirmação de direitos através dos membros individuais da coletividade nacional. (p.189-190)

A dimensão "cívica” proposta por Kelly traduz-se em linhas gerais em cidadania participativa e a dimensão "civil”, traduziria, guardadas as devidas proporções, a cidadania protetora.

\subsection{Cidadania: aspectos jurídicos}

\subsubsection{Cidadania sob enfoque jurídico-constitucional}

Para tratarmos o tema da cidadania no campo jurídico, mais especificamente em um enfoque constitucional, nos deteremos em duas abordagens que nos parecem ser as mais recorrentes na bibliografia. A primeira seria a relação entre os conceitos de "nacionalidade" e de "cidadania", ora apresentados como sinônimos, ora apresentados como noções autônomas, embora interdependentes; a segunda seria o estabelecimento do conteúdo abarcado pela idéia de cidadania. Essa segunda abordagem gera duas posições básicas: de um lado a identificação do conceito de cidadania com direitos políticos, notadamente o direito ao voto, que é a dimensão tradicionalmente enfatizada pelos juristas e de outro a constatação de que a noção de cidadania comportaria um alargamento de significado que vai além de seu aspecto estritamente eleitoral.

Em relação à primeira forma de abordagem, ou seja, a discussão envolvendo as noções de "nacionalidade" e "cidadania", podemos dizer que a história constitucional 
brasileira ilustra uma trajetória vai desde a confusão ou indistinção entre esses termos, até a demarcação da diferença entre eles.

"Nacionalidade" é uma palavra que remete à "nação," e tem o sentido ligado a nascimento, origem, evocando, etimologicamente, o vocábulo latino natio. Nos termos da Constituição de 1988, nacionalidade é o vínculo jurídico da pessoa humana em relação ao território nacional, por nascimento (brasileiro nato) ou naturalização (brasileiro naturalizado). Cidadania seria um atributo político que se liga àquele que possui a nacionalidade; decorre do "direito de participar do governo e direito de ser ouvido pela representação política”. (SILVA, 2009, p.211) Nacionalidade seria, portanto, um termo mais amplo do que cidadania.

Note-se que a amplitude das possibilidades participativas de um cidadão varia de acordo com a situação de se tratar de brasileiro nato ou naturalizado. A regra geral é que não pode haver diferenças de tratamento entre brasileiros e que o brasileiro naturalizado goza de todos os direitos políticos de um brasileiro nato. Entretanto, a Constituição pode marcar diferenças entre eles indicando atribuições exclusivas de brasileiros natos, como é o caso do art. 12, $\S 3^{\circ}$ da Constituição de 1988 que estipula que são privativos de brasileiro nato, os cargos:

\footnotetext{
I - de Presidente e Vice-Presidente da República;

II - de Presidente da Câmara dos Deputados;

III - de Presidente do Senado Federal;

IV - de Ministro do Supremo Tribunal Federal;

V - da carreira diplomática;

VI - de oficial das Forças Armadas;

VII - de Ministro de Estado da Defesa.
}

Conforme Haroldo Valladão (1977), no direito brasileiro imperial e na Primeira República as referências à condição de cidadão eram aplicadas para definir o que depois veio a chamar-se nacionalidade.

De fato, na Constituição de 1824 , o termo "cidadão ${ }^{46 "}$ está no sentido do que poderíamos entender por "nacional" de forma que o art. $6^{\circ}$ indica, sob a epígrafe "dos cidadãos brasileiros", as condições em que se adquire a nacionalidade brasileira ${ }^{47}$.

\footnotetext{
${ }^{46}$ Lembremos que em 1824 o termo "cidadania" não estava ainda em uso corrente em língua portuguesa (pelo menos ainda não dicionarizado) (ver item 1.1 do presente trabalho). É curioso notar que no texto da Constituição de 1824 há a citação do termo "cidadão" 21 vezes, em diversos contextos (Art. 1", Título II, Art 6, Art. $7^{\circ}$, Art. $9^{\circ}$, Art 45, I, Art. 71, Art. 90, Art. 91, I; Art. 96, Art. 133, V; Título VIII; Art. 178; Art.
} 
Utilizava-se no contexto da Constituição Imperial, o conceito de "cidadão ativo" para designar a condição daqueles que possuíam direitos políticos plenos, ou seja, votar e ser votado.

Assim, diz o art. 90 da Constituição de 1824:

as nomeações dos Deputados, e Senadores para a Assembléa Geral, e dos Membros dos Conselhos Geraes das Provincias, serão feitas por Eleições indirectas, elegendo a massa dos Cidadãos activos em Assembléas Parochiaes os Eleitores de Provincia, e estes os Representantes da Nação, e Provincia. (grifo nosso).

O grande comentarista da Constituição do Império, Pimenta Bueno, afirma que os direitos políticos são "as prerrogativas, os atributos, faculdades ou poder de intervenção dos cidadãos ativos no governo de seu país (...)” (1958, p. 458)

Trata-se da consubstanciação da forma liberal de conceber cidadania, ou seja, a condição de cidadão dá proteção ao indivíduo em relação à ingerência do Estado em sua vida particular. Mas há uma estratificação entre cidadãos, de forma que só parte deles, os ativos, é que detém direitos políticos. E essa separação é feita por critérios censitários, além do que as mulheres estão de antemão afastadas. Ademais, é possível inferir do sistema, a existência de "não-cidadãos", categoria aplicável aos escravos.

179 caput, Art. 179, I, Art. 179, VII, Art. 179, XIV, Art. 179, XXII, Art. 179, XXIV, Art. 179, XXX; Art. 179, XXXII) . Esse dado revela que essa constituição é, na história constitucional brasileira, aquela que se utiliza do maior número de citações da palavra. A "constituição cidadã" de 1988 possui 7 citações do termo

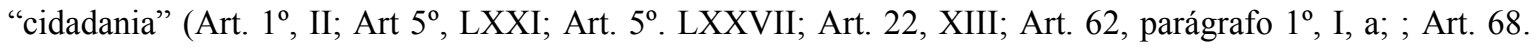
Parágrafo $1^{\circ}$, II, Art. 205); 8 citações da palavra "cidadão" no texto original (Art. 5, LXXIII; Art. 58, parágrafo $2^{\circ}$, V; Art. 61; Art. 74, parágrafo $2^{\circ}$; Art. 89, VII; Art. 98,II; Art. 101; Art. 131 parágrafo $1^{\circ}$ ), mais 2 citações incluídas por meio da emenda constitucional n.45 (Art 103 B, XIII e Art. 130 A, VI) e 2 citações no Ato das Disposições Constitucionais transitórias (Art. $8^{\circ}$, Parágrafo $3^{\circ}$; Art. 64). Entretanto, como é óbvio notar, a quantidade de citações da palavra "cidadão" e a ausência total da palavra "escravidão" do texto constitucional de 1824 (condição social que efetivamente marcava a sociedade brasileira da época) nos dá a medida do sentido excludente em que o termo estava sendo utilizado.

${ }^{47}$ Art. 6. São Cidadãos Brazileiros

I. Os que no Brazil tiverem nascido, quer sejam ingenuos, ou libertos, ainda que o pai seja estrangeiro, uma vez que este não resida por serviço de sua Nação.

II. Os filhos de pai Brazileiro, e os illegitimos de mãe Brazileira, nascidos em paiz estrangeiro, que vierem estabelecer domicilio no Imperio.

III. Os filhos de pai Brazileiro, que estivesse em paiz estrangeiro em sorviço do Imperio, embora elles não venham estabelecer domicilio no Brazil.

IV. Todos os nascidos em Portugal, e suas Possessões, que sendo já residentes no Brazil na época, em que se proclamou a Independencia nas Provincias, onde habitavam, adheriram á esta expressa, ou tacitamente pela continuação da sua residencia.

V. Os estrangeiros naturalisados, qualquer que seja a sua Religião. A Lei determinará as qualidades precisas, para se obter Carta de naturalisação. 
A ideologia liberal marca fortemente as concepções sobre as quais o Direito Brasileiro se assenta, desde a nossa primeira Constituição. Paulo Bonavides e Paes de Andrade, nesse sentido, esclarecem que "o constitucionalismo do Império introduziu no País uma forma política de organização do poder que se inspirava em grande parte nos princípios fundamentais da ideologia liberal”. (2008, p. 202)

A Constituição Republicana de 1891 também confunde a condição do cidadão com a condição do nacional, utilizando apenas o termo "cidadão ${ }^{48}$ ".

A separação desses conceitos inicia-se na Constituição de 1937, para firmar-se nas constituições subseqüentes (SILVA,2009, p. 211) de forma que a Constituição de 1988 acolhe a diferenciação e apresenta capítulo específico para nacionalidade ${ }^{49}$ (Título II, Capítulo III) deixando clara a distinção em relação à cidadania inclusive quando aponta a competência da União para legislar sobre nacionalidade, cidadania e naturalização, como institutos separados (art. 22, XIII).

Manoel Gonçalves Ferreira Filho sintetiza a diferença entre nacionalidade e cidadania:

É largamente difundido no Brasil, o uso da expressão cidadão para designar todo e qualquer nacional. Em realidade, a bem da clareza, se deve caracterizar a

\footnotetext{
${ }^{48}$ Art. 69. São cidadãos brasileiros:

$1^{\circ}$ ) os nascidos no Brasil, ainda que de pai estrangeiro, não, residindo este a serviço de sua nação;

$2^{\circ}$ ) os filhos de pai brasileiro e os ilegítimos de mãe brasileira, nascidos em país estrangeiro, se estabelecerem domicílio na República;

$3^{\circ}$ ) os filhos de pai brasileiro, que estiver em outro país ao serviço da República, embora nela não venham domiciliar-se;

$4^{\circ}$ ) os estrangeiros, que achando-se no Brasil aos 15 de novembro de 1889, não declararem, dentro em seis meses depois de entrar em vigor a Constituição, o ânimo de conservar a nacionalidade de origem;

$5^{\circ}$ ) os estrangeiros que possuírem bens imóveis no Brasil e forem casados com brasileiros ou tiverem filhos brasileiros contanto que residam no Brasil, salvo se manifestarem a intenção de não mudar de nacionalidade; $\left.6^{\circ}\right)$ os estrangeiros por outro modo naturalizados.

${ }^{49}$ Art. 12. São brasileiros:

I - natos:

a) os nascidos na República Federativa do Brasil, ainda que de pais estrangeiros, desde que estes não estejam a serviço de seu país;

b) os nascidos no estrangeiro, de pai brasileiro ou mãe brasileira, desde que qualquer deles esteja a serviço da República Federativa do Brasil;

c) os nascidos no estrangeiro de pai brasileiro ou de mãebrasileira, desde que sejam registrados em repartição brasileira competente ou venham a residir na República Federativa do Brasil e optem, em qualquer tempo, depois de atingida a maioridade, pela nacionalidade brasileira;

II - naturalizados:

a) os que, na forma da lei, adquiram a nacionalidade brasileira, exigidas aos originários de países de língua portuguesa apenas residência por um ano ininterrupto e idoneidade moral;

b) os estrangeiros de qualquer nacionalidade, residentes na República Federativa do Brasil há mais de quinze anos ininterruptos e sem condenação penal, desde que requeiram a nacionalidade brasileira.
} 
nacionalidade como um status cujo conteúdo só se esclarece por contraposição ao do estrangeiro (...) Por sua vez, a cidadania ( em sentido lato) é o status de nacional acrescido dos direitos políticos (stricto sensu), isto é, poder participar do processo governamental, sobretudo pelo voto. Destarte, a nacionalidade- no direito brasileiro é condição necessária mas não suficiente da cidadania.(2003,p.114)

De fato, é comum o uso do termo "cidadania" no lugar de nacionalidade, reforçado pelo fato de que a marcação clara dessa diferenciação não é universal, não é cuidada em ordenamentos jurídicos de outros países, que usam "cidadania" indistintamente, como é o caso da Itália (BALLARINO,2003) e dos Estados Unidos, conforme podemos concluir da leitura da $14^{a}$ Emenda à Constituição, seção I que diz que "todas as pessoas nascidas ou naturalizadas nos Estados Unidos, e sujeitas à sua jurisdição, são cidadãos dos Estados $\operatorname{Unidos}^{50}(\ldots)$.

Além disso, há a falta de unanimidade na própria doutrina do Direito Constitucional nacional, e é exemplar nesse sentido, que o manual de Direito Constitucional do grande publicista Pinto Ferreira (2002), mesmo atualizado em relação à Constituição de 1988, não diferencie nacionalidade de cidadania.

A indistinção também é indicada por Celso Lafer ao esclarecer que:

O termo nacionalidade e o termo cidadania freqüentemente são utilizados como sinônimos, ainda que a identificação entre os dois, em distintos sistemas jurídicos nacionais, nem sempre seja correta. A cidadania pressupõe nacionalidade, mas o nacional pode estar legalmente incapacitado para exercer a cidadania, ou seja, os seus direitos políticos. É o caso, por exemplo, do menor, até ele atingir a maioridade política, dos interditados, e em certos países dos analfabetos ou dos condenados a penas de reclusão. Entretanto, como a nacionalidade é o vínculo jurídico político entre um Estado soberano e um indivíduo, que faz deste indivíduo membro de uma comunidade política e, conseqüentemente, parte integrante da competência pessoal do Estado, os textos de Direito internacional Público contemporâneo, em matéria de direitos humanos, tendem a assimilar a nacionalidade à cidadania. (2006a, p.135)

Para Jorge Miranda, a utilização da palavra "cidadania" seria mais precisa do que "nacionalidade", pois, entre outros motivos, é possível se falar em nacionalidade de uma embarcação, nacionalidade de mercadorias, "mas cidadania só possuem as pessoas singulares". (2009, p.102)

Permanece, a nosso ver, válida a lição de A. Dardeau de Carvalho que, comentando o fato de os Estados Unidos não fazerem a diferenciação entre nacionalidade e cidadania,

50 Aqui estamos utilizando o texto em português, conforme "A Constituição dos EUA anotada" (ALVAREZ E NOVAES FILHO) O texto original diz: "All persons born or naturalized in the United States, and subject to the jurisdiction thereof, are citizens of the United States"(...)(acessível no site <www.planalto.gov.br> por meio do link "Constituições de outros países." 
explica que os dois termos não designam mais do que dois momentos de um mesmo fenômeno e que "é meramente convencional e, por isso, dependente do critério adotado nos diferentes países, que nem sempre observam na prática a distinção doutrinária por muitos admitida." (1950, p. 250)

Assim, em que pese a diferença constitucional entre "cidadania" e "nacionalidade" delineada no excerto que citamos de FERREIRA FILHO, parece que na prática dos usos discursivos, a confusão ainda persiste.

De qualquer forma, a idéia de que cidadania envolve gozo de direitos políticos, nos leva diretamente à segunda abordagem feita pelos juristas quando tratam da temática da cidadania, ou seja, a determinação do conteúdo da cidadania. A cidadania teria como conteúdo os direitos políticos, segundo a posição mais tradicionalmente encontrada nas abordagens de enfoque jurídico. Os trechos de FERREIRA FILHO e LAFER que citamos acima, já revelam essa vinculação cidadania-direitos políticos que estamos a apontar.

Note-se a forma de enunciação de ARAÚJO e NUNES JÚNIOR indicando que direitos políticos e direitos de cidadania são sinônimos: "os direitos políticos, ou de cidadania, resumem o conjunto de direitos que regulam a forma de intervenção popular no governo". (2001, p.174)

José Afonso da Silva escreve que "os direitos de cidadania adquirem-se mediante alistamento eleitoral na forma da lei” (2008, p. 346) evidenciando o caráter político estrito do conceito. Em outro trecho, o autor, de forma sintética, resume a questão, sob o prisma do Direito: “cidadão', no Direito Brasileiro, é o indivíduo que seja titular dos direitos políticos de votar e ser votado, e suas conseqüências”. (2009, p.211)

$\mathrm{O}$ vínculo entre cidadania e direitos políticos é uma das visões dominantes no campo jurídico. E direitos políticos costumam ser resumidos em direito de voto, como é possível notar no próprio conceito de direitos políticos indicado pelo art. 38 da Lei 818/49: "são direitos políticos aqueles que a Constituição e as Leis atribuem a brasileiros, precipuamente o de votar e ser votado".

Embora a noção de cidadania restrita principalmente ao voto ainda possua amplo apelo discursivo, não se pode dizer que esse conteúdo restrito seja a forma unânime de se encarar a cidadania sob o prisma jurídico, principalmente, após a promulgação da Constituição de 1988. Seria pertinente traçar um brevíssimo panorama da visão jurídica sobre cidadania no momento imediatamente anterior à Constituição de 1988.

Podemos dizer que até a década de 1980, a cidadania não era sequer um tema a ser considerado pelos estudiosos do Direito. 
Leia-se o diagnóstico de Francisco Messias ao estudar a dimensão jurídica da cidadania, no final da década de 1970, início dos anos 80:

\begin{abstract}
O exame da doutrina jurídica pertinente nos leva a inevitável conclusão de que a cidadania não é, decididamente, um tema muito trabalhado pelos juristas, ou, pelo menos, à certeza de que não há muita clareza e uniformidade no pouco que se escreve a respeito da questão. Isso devido ao fato de não haver estudos específicos sobre o tema e também por ser o mesmo tratado de maneira a que se estabeleça uma relativa confusão com outros conceitos, como nacionalidade e direitos políticos. (1981, p.29)
\end{abstract}

A cidadania, do ponto de vista jurídico, estaria ligada estritamente aos direitos políticos, de tal sorte que não haveria "conteúdo sócio-econômico no conceito jurídico de cidadania". (MESSIAS, 1981, p.34)

$\mathrm{Na}$ verdade, o autor reivindica, em sua dissertação, uma abertura do conceito de cidadania para além dos direitos políticos, com base em uma leitura de Marshall, cuja obra já comentamos no item anterior.

Esse alargamento do sentido de cidadania aparece também em artigo de Dalmo Dallari publicado em 1981:

Em muitos teóricos, a questão da cidadania ainda é encontrada ligada aos chamados direitos políticos, quase que reduzidos a direitos eleitorais. $\mathrm{Na}$ verdade, hoje cidadania comporta uma concepção muito mais ampla, reconhecendo-se que a afirmação dos direitos políticos é insuficiente se não se reconhecer, também, uma possibilidade econômica e uma possibilidade social.

(DALLARI apud MESSIAS, 1981, p.40)

Um dos trabalhos mais esclarecedores no que concerne ao estabelecimento do panorama da cidadania sob o prisma jurídico, antes da Constituição de 1988, foi escrito por Vera Regina Pereira de Andrade, sob a forma de dissertação de mestrado defendida em 1988 na Universidade Federal de Santa Catariana. O trabalho foi publicado em 1993 e há um artigo da autora que retoma algumas diretrizes da dissertação, publicado em 1998, ao qual faremos referência.

A autora classifica a cidadania, pelo menos no momento histórico em que a analisa, como um "epifenômeno jurídico", um instituto sem dignidade científica própria no universo jurídico, um fenômeno acessório a pedir licença em obras de Direito Constitucional nos capítulos que tratam da nacionalidade e direitos políticos e em obras de Teoria Geral do Estado, em capítulos que tratam do conceito de povo. 
Em um levantamento bibliográfico representativo do que se produzia sobre cidadania na época de sua pesquisa, a autora conclui que:

\begin{abstract}
A cidadania não é um tema pelo qual os juristas se sintam interpelados a tratar com profundidade, não parecendo exagerado afirmar que, no universo jurídico, ocupe a posição de epifenômeno, cujos temas centrais envolvidos são nacionalidade, o povo e os direitos políticos. (1993, p.27)
\end{abstract}

A autora procura demonstrar que a cultura jurídica positivista dominante no Brasil propiciadora de um discurso pretensamente científico e neutro, estaria a serviço das proposições da ideologia liberal $^{51}$, em especial, no tocante à sua hostilidade a formas de participação política mais amplas que extrapolem o ritual do voto, em um sistema representativo. Dessa forma, a cidadania seria delineada em um aspecto meramente formal, como instituto jurídico dogmático estático, impermeável às mudanças trazidas pela dinâmica da realidade social.

A valorização desmedida dos direitos políticos ocultaria a existência de outras dimensões da cidadania, de forma que a autora recorre ao modelo de Marshall, indicando os feixes de direitos civis e sociais, como esferas a serem consideradas no conceito jurídico de cidadania. A proposta mais explícita advinda da obra da autora seria a superação das limitações impostas pelo modelo liberal de cidadania em direção da "obtenção de um estatuto próprio para a cidadania, no saber jurídico, onde possa ser tematizada a partir de sua materialidade social". (1993, p.137)

Com a mudança do panorama a partir da Constituição de 1988, a mesma autora que apontou para a falta de densidade dos juristas no trato da temática da cidadania, reconhece, em 1998, que "talvez nenhum outro tema tenha se consolidado, na teoria e na praxis, na academia e na rua, no discurso oficial e nos discursos oficiosos do cotidiano com tamanha força”. (ANDRADE, 1998, p. 123)

O fato de a Constituição de 1988 indicar que a cidadania é um dos fundamentos do Estado Brasileiro deu ao conceito outro estatuto; além disso, a participação do cidadão foi enriquecida no texto constitucional, por um leque maior de possibilidades o que acarretou, naturalmente, um maior destaque para o tema que passou a ser mais discutido em artigos e trabalhos acadêmicos, inclusive no campo jurídico.

\footnotetext{
${ }^{51}$ Diz a autora: "a titularidade de direitos políticos stricto sensu, como estigma da cidadania, corresponde a uma ideologia política específica, historicamente configurada: o modelo liberal de exercício do poder. É esse modelo- e não qualquer um - que apresenta a cidadania assim caracterizada, de modo que se pode afirmar com segurança a vinculação do discurso jurídico da cidadania à Mariz político-ideológica liberal, e ao seu correlato de democracia representativa." (ANDRADE, 1993, p. 40)
} 
De fato, conforme, Ricardo Lobo Torres,

No Brasil o resgate da cidadania, em seu sentido jurídico, encontrou o seu ponto culminante no art. $1^{\circ}$, inciso II, da Constituição de 1988 , que a incluiu entre os fundamentos do Estado Democrático de Direito, abrindo novas perspectivas para a análise do tema.(1999, p.249)

Portanto, não se pode mais dizer, como na década de 1980, que os juristas pouco se interessam pelo tema da cidadania, tendo em vista a sua presença ostensiva no próprio texto constitucional.

Mas como o tema se apresenta na Constituição de 1988 ?

Ulysses Guimarães, por ocasião do término dos trabalhos da Assembléia Nacional Constituinte que elaborou o texto constitucional de 1988, proferiu um discurso em que se evidencia o papel fortemente participativo que se imaginava proporcionar ao cidadão com a nova Constituição:

\begin{abstract}
Pela Constituição, os cidadãos são poderosos e vigilantes agentes da fiscalização, através do mandado de segurança coletivo; do direito de receber informações dos órgãos públicos, da prerrogativa de petição aos poderes públicos, em defesa de direitos contra ilegalidade ou abuso de poder, da obtenção de certidões para defesa de direitos; da ação popular, que pode ser proposta por qualquer cidadão, para anular ato lesivo ao patrimônio público, ao meio ambiente e ao patrimônio histórico, isento de custas judiciais; da fiscalização das contas dos municípios por parte do contribuinte; podem peticionar, reclamar, representar ou apresentar queixas junto às comissões das Casas do Congresso Nacional; qualquer cidadão, partido político, associação ou sindicato são partes legítimas e poderão denunciar irregularidades ou ilegalidades perante o Tribunal de Contas da União, do estado ou do município. A gratuidade facilita a efetividade dessa fiscalização. A exposição panorâmica da lei fundamental hoje passa a reger a Nação permite conceituá-la, sinoticamente, como a Constituição coragem, a Constituição cidadã, a Constituição federativa, a Constituição representativa e participativa, a Constituição do Governo síntese Executivo-Legislativo, a Constituição fiscalizadora. (Ata da Assembléia Nacional Constituinte Diário da Assembléia Nacional Constituinte ano II $n^{\circ} 308,05.10 .1988$ )
\end{abstract}

Convém lembrar que o texto constitucional em vigor não apresenta um conceito de cidadania. Entretanto, as diversas indicações do papel do cidadão nos permite compor algumas de suas dimensões, que vão além do voto ${ }^{52}$.

Em termos constitucionais, podemos identificar a cidadania como um conjunto de direitos e deveres que permitem, entre outras atividades, a participação política na gestão dos negócios públicos por meio dos instrumentos da democracia representativa (voto, candidatura a cargos públicos) e por meio de instrumentos de democracia semi-direta

\footnotetext{
${ }^{52}$ Há uma lista extensa das manifestações da cidadania no texto constitucional em LOPES, 2006.
} 
(plebiscito, referendo e iniciativa popular); participação em órgãos, conselhos, comitês gestores $^{53}$ que auxiliam na gestão das ações do Poder Público; o exercício da fiscalização do poder ${ }^{54}$; a reivindicação de direitos frente aos poderes públicos ${ }^{55}$.

Nesses sentidos apontados, e até pela intenção expressa na fala de Ulysses Guimarães que reproduzimos mais acima, nota-se a forte vinculação da noção de cidadão não só à idéia de voto, mas também a outras modalidades de participação na esfera pública.

É certo que a visão de cidadania, sob o prisma jurídico-constitucional, pode igualar, em alguns momentos, o cidadão à figura do eleitor, exigindo-se, inclusive, a posse do documento eleitoral para a concretização da participação cidadã. Assim, em relação à propositura de ação popular (nota $n^{\circ} 11$ ) que é um instrumento exemplar do poder do cidadão de agir em nome do interesse público, tem como componente identificador do cidadão, a qualidade de eleitor ${ }^{56}$ :

O primeiro requisito para o ajuizamento da ação popular é que o autor seja cidadão brasileiro, isto é, pessoa humana, no gozo de seus direitos cívicos e políticos, requisito, esse, que se traduz na qualidade de eleitor. Somente o indivíduo (pessoa física) munido de seu título eleitoral poderá propor ação popular, sem o quê será carecedor dela. Os inalistáveis ou inalistados, bem como os partidos políticos, entidades de classe ou qualquer outra pessoa jurídica não têm qualidade para propor ação popular. (STF, sumula 365). Isso porque tal ação se funda essencialmente no direito político do cidadão, que, tendo o poder de escolher os governantes, deve ter, também, a faculdade de fiscalizar os atos de administração (MEIRELLES, 2005, p.132)

\footnotetext{
${ }^{53}$ Exemplos: Art. 103-B. O Conselho Nacional de Justiça compõe-se de quinze membros com mais de trinta e cinco e menos de sessenta e seis anos de idade, com mandato de dois anos, admitida uma recondução, sendo (...)XIII - dois cidadãos, de notável saber jurídico e reputação ilibada, indicados um pela Câmara dos Deputados e outro pelo Senado Federal; Art. 198. As ações e serviços públicos de saúde integram uma rede regionalizada e hierarquizada e constituem um sistema único, organizado de acordo com as seguintes diretrizes: (...) III- participação da comunidade; Art. 204. As ações governamentais na área da assistência social serão realizadas com recursos do orçamento da seguridade social, previstos no art. 195, além de outras fontes, e organizadas com base nas seguintes diretrizes:(...)II - participação da população, por meio de organizações representativas, na formulação das políticas e no controle das ações em todos os níveis.

${ }^{54}$ Exemplo: Art. $5^{\circ}$, LXXIII - qualquer cidadão é parte legítima para propor ação popular que vise anular ato lesivo ao patrimônio público ou de entidade de que o Estado participe, à moralidade administrativa, ao meio ambiente e ao patrimônio histórico e cultural, ficando o autor, salvo comprovada má-fé, isento de custas judiciais e do ônus da sucumbência".

${ }^{55}$ Exemplo: Art. 5º ${ }^{\circ}$ LXXVII- são gratuitas as ações de "habeas-corpus" e "habeas-data", e, na forma da lei, os atos necessários ao exercício da cidadania.

56 José Afonso da Silva reconhece que essa interpretação restrita é pacífica na doutrina e jurisprudência, mas não deixa de indicar a sua opinião, comentando que o uso do termo "cidadão" só teria a finalidade de excluir estrangeiros e pessoas jurídicas. Considerando o sentido ampliado de cidadania contido na Constituição de 1988, o sentido mais apropriado para "cidadão", no artigo 5, LXXIII, seria "qualquer brasileiro". (2007, p.158)
} 
Como observa Machado de Assis em trecho saboroso de uma crônica do ano de 1896, a posse do documento eleitoral é constitutiva da condição de eleitor:

\begin{abstract}
A verdadeira teoria política é que não há eleitores, há títulos. Um eleitor que é? Um simples homem, não diverso de outro homem que não seja eleitor; a mesma figura, os mesmos órgãos, as mesmas necessidades, a mesma origem, o mesmo destino; às vezes, o mesmo alfaiate; outras, a mesma dama. Que é que os faz diferentes? Êsse pedaço de papel que leva em si um pedaço da soberania. O homem pode ser banqueiro, agricultor, operário, comerciante, advogado, médico, pode ser tudo; eleitoralmente é como se não existisse: sem título, não é eleitor". (1957, p.366)
\end{abstract}

É preciso ressaltar que, no texto constitucional, a palavra cidadania não é utilizada em um sentido único, o que, evidentemente contribui para as dificuldades de estabelecer um entendimento sobre o vocábulo. Às vezes aparece como direitos políticos, na acepção mais estreita possível como no caso do uso da expressão "cidadão" como titular da ação popular. Às vezes aparece em sentido ampliado. José Afonso da Silva lembra que no art. $1^{\circ}$, II da Constituição, quando cidadania é mencionada como fundamento do Estado Democrático de Direito, devemos ter uma visão do termo "num sentido mais amplo do que o titular de direitos políticos." Nesse caso, cidadania "qualifica os participantes da vida do Estado, o reconhecimento do indivíduo como pessoa integrada à sociedade estatal”. (2008, p. 104)

Esse sentido ampliado pode ser entendido como algo além do estrito exercício do direito ao voto, indicando outras formas de participação na esfera política, que vão desde a utilização de instrumentos como o plebiscito, iniciativa popular e referendo, até a possibilidade participar da composição de órgãos e comitês do Poder Público.

Mas os autores que discutem a noção de cidadania a partir da Constituição Federal de 1988, também apontam que o sentido "ampliado" de cidadania iria para além da esfera de participação política.

Ao apresentar a sua obra, Tratado Geral da Cidadania, José Alfredo de Oliveira Baracho nos oferece um exemplo de uma forma ampliada de os juristas olharem para o problema da cidadania, após a Constituição de 1988:

\footnotetext{
Neste trabalho, procuramos mostrar a nova concepção que se tem de cidadania, e seus reflexos na vida das pessoas, demonstrando que eles não se esgotam apenas na clássica participação política, através dos instrumentos criados pela democracia representativa e democracia direta.
} 
A Constituição Brasileira de 1988 ampliou o conteúdo do termo "cidadania", que não pode ser visto apenas em sua projeção política e jurídica clássica ${ }^{57}$.(1995, p.V)

Também com uma visão menos restrita do conceito de cidadania, Uadi Lammêgo Bulos discorre sobre a noção explicando que:

\begin{abstract}
A Constituição de 1988 ampliou, consideravelmente, o conteúdo do termo. Isso exige do intérprete uma visão mais elástica de cidadania, que não pode ser examinada nos moldes tradicionais. (...) ela passou a abranger todos os participantes da vida do Estado brasileiro, incluindo-se os titulares de direitos políticos. (2007, p.82)
\end{abstract}

O autor diz que a noção incluiria os "titulares de direitos políticos" sendo razoável, seguindo o autor, dizer então que a abrangência elástica da cidadania incluiria também aqueles que não seriam titulares de direitos políticos.

João Baptista Herkenhoff também se expressa em termos de alargamento do significado de cidadania, em seu livro "Cidadania para todos":

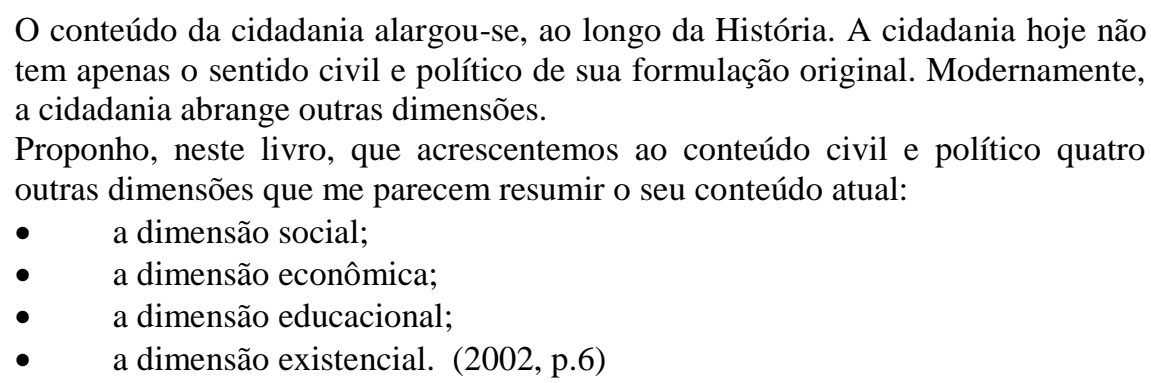

Assim a Constituição de 1988, embora apresente a descrição de hipóteses que nos remetem à cidadania em seu sentido político (seja estrito, como que reduzido a direito eleitoral, seja mais amplo para abarcar outras formas de participação), há também o enaltecimento dos direitos sociais, dos direitos econômicos, entre outros, permitindo uma diluição da preponderância exclusiva dos direitos políticos como conteúdo da cidadania.

Conforme procuramos demonstrar, em relação àquele quadro referente ao início da década de 1980, houve uma clara mudança de percepção. Na verdade, no decorrer da década de 1990 e nessa primeira década do século XXI, o pêndulo movimentou-se de um

\footnotetext{
${ }^{57} \mathrm{O}$ autor focará no seu trabalho, o problema do direito de acesso ao Poder Judiciário e as garantias processuais constitucionais envolvidas nesse direito. A concretização da cidadania não seria possível sem a possibilidade dos meios judiciais de sua efetivação.
} 
sentido restrito de cidadania para outro extremo, em que a palavra cidadania, vitalizada por uma positividade poderosa, é empregada para dar legitimidade a qualquer discurso político-social.

\subsubsection{Cidadania e direitos humanos}

Retomando a teoria desenvolvida por Marshall, conforme vimos no item 3.2.3, lembremos que o conceito de cidadania daquele autor é calcado nos mesmos direitos que fazem parte da teoria dos direitos humanos.

A idéia da cidadania enquanto feixes de direitos civis, políticos e sociais que vão se somando, possui uma relação direta com a bibliografia específica da área de direitos humanos, onde se encontra um discurso de "etapas" na formulação de direitos humanos58 bastante conhecido e que é semelhante ao de Marshall.

Como já explicitamos, os direitos humanos são apresentados como uma lenta construção histórica, com o surgimento de "gerações" de direitos correspondentes ao momento histórico em que se fizeram necessários, sendo comum o apontamento de declarações e documentos representativos que sinalizam a presença real de tais direitos.

Conforme apontamos é recorrente na doutrina dos direitos humanos, o discurso marcando o aparecimento dos direitos em gerações ou dimensões de direitos. A primeira geração corresponderia aos direitos civis ( propriedade, liberdade de expressão, liberdade religiosa, etc) e políticos (direito ao voto).

Os direitos de segunda geração correspondem a demandas sociais face ao Estado correspondendo aos direitos sociais, econômicos e culturais como trabalho, seguridade social, educação e saúde.

Os direitos de terceira geração corresponderiam $\mathrm{m}$ aos direitos de solidariedade cuja titularidade ultrapassa o interesse individual ou de um grupo social delimitado, mas a atinge a todos, como é o caso do direito ao meio-ambiente sadio, direito à paz, etc.

Coube ao jurista Karel Vlasak em palestra proferida na Academia de Direito de Estrasburgo em 1979, a menção aos direitos de terceira geração fazendo uma correlação das gerações de direito com a bandeira francesa: os direitos civis e políticos

${ }^{58}$ Ver item 1.2 supra. 
corresponderiam ao lema liberdade, os direitos sociais ao lema igualdade e os direitos coletivos ao lema fraternidade.

Essa classificação de direitos humanos (gerações ou dimensões sucessivas e complementares), portanto, guarda uma similaridade em relação ao modelo evolutivo do conteúdo da cidadania na sociedade inglesa, proposto por Marshall.

Entretanto, no modelo de Marshall há uma cisão entre os direitos civis e políticos, com o aparecimento primeiro dos direitos civis sucedidos pelos direitos políticos, enquanto é praxe na descrição do surgimento dos direitos humanos afirmar que os direitos civis e políticos formam um único conjunto de direitos sob o manto classificatório de "primeira geração de direitos".

Ainda em Marshall, os direitos sociais formariam a etapa final da construção do conceito de cidadania, enquanto na teoria dos direitos humanos, esses mesmos direitos formariam a segunda geração, que ainda é sucedida e complementada por uma terceira, envolvendo direitos de titularidade coletiva, como o direito a um meio ambiente equilibrado, não mencionados por Marshall.

Mas o que nos importa destacar é que no modelo de Marshall assume-se que cidadania é o termo geral para nomear o conjunto dos direitos civis, políticos e sociais (“direitos de cidadania") enquanto na teoria dos direitos humanos, o termo cidadania parece estar ligado mais especificamente aos direitos políticos. Se considerarmos a Declaração Universal dos Direitos do Homem e do Cidadão de 1789, a divisão homem/cidadão indicaria que os direitos humanos são destinados a todos os homens, independentemente de origem, cor, condição social, etc; mas os direitos de cidadão (direitos políticos) dependeriam do vínculo jurídico com um Estado.

Para alguns autores da área jurídica, a convivência entre a teoria da cidadania (conforme Marshall) e a teoria dos direitos humanos, é problemática de tal sorte que destacam que há nessa relação uma confusão conceitual que é preciso pelo menos ser mencionada, e que podemos expressar reproduzindo algumas perguntas de Michelângelo Bovero sobre a questão:

Teoria da cidadania e teoria dos direitos do homem devem ser consideradas simplesmente como duas formas lexicais distintas para tratar da mesma substância problemática? São dois dicionários para um mesmo conteúdo conceitual? O léxico da cidadania é simplesmente uma variante anglo-americana recente do léxico clássico-moderno dos direitos do homem? (2002, p. 118)

Como sabemos, cidadania evoca, de maneira fundamental, a vinculação do indivíduo a um Estado-nação. Já os direitos do homem, não estariam sujeitos a uma 
vinculação da pessoa a um Estado de forma que não dependeriam da condição de cidadão para serem gozados. Assim, para Bovero, essas teorias possuem uma afinidade ilusória. Sua crítica assenta-se na constatação de que os direitos humanos não dependeriam da cidadania para serem atribuídos, pois são universais, pertencentes a todos os homens e que o uso do termo "cidadania" como gênero, ou um rótulo sob o qual se abrigam todas as esferas de direitos, daria uma conotação de dependência entre direitos e o Estado.

O termo "cidadania" aplicar-se-ia principalmente a uma das espécies de direitos, no caso, direitos políticos, e seria um equívoco conceitual elevar essa espécie à condição de gênero.

A questão levantada por Bovero tem uma singular importância nos países de capitalismo avançado da Europa por conta do fluxo migratório intenso das últimas décadas reacendendo o debate sobre as garantias que esses estrangeiros teriam e se o uso do conceito de cidadania não estaria servindo para excluí-los do gozo de direitos.

Luigi Ferrrajoli, analisando a concepção de "direitos de cidadania" de Marshall, explica que:

\begin{abstract}
Semelhante tese, que está em contradição com todas as constituições modernasnão só a Declaração Universal de Direitos de 1948, senão também com a maior parte das constituições estatais que conferem quase todos estes direitos às "pessoas" e não só aos "cidadãos"- tem sido reavaliada nos últimos anos, precisamente quando nossos acomodados países e nossas ricas cidadanias começaram a ser ameaçadas pelo fenômeno das imigrações em massa. Em resumo, chegado o momento de tomar a sérios os direitos fundamentais, tem-se negado sua universalidade, condicionando todo o seu catálogo à cidadania independentemente do fato de que quase todos, excetuados os direitos políticos e alguns direitos sociais, são atribuídos pelo direito positivo- tanto estatal quanto internacional- não só a cidadãos como também a todas às pessoas. ( 2007, p.4041)
\end{abstract}

Por outro lado, muitos cientistas sociais que trabalham com o conceito de "direitos de cidadania" têm preocupações similares aos juristas e chegam a um resultado teórico e prático semelhante, por um caminho diferente. É que no lugar de, como fazem os juristas que citamos, reservar ao termo "cidadania" um sentido excludente e ao termo "pessoa" um sentido universal, tendem a defender um uso mais universal do próprio termo "cidadania", conforme podemos inferir da seguinte passagem do sociólogo Liszt Vieira:

A cidadania clássica, baseada na nacionalidade, sempre excluiu os não-cidadãos dos direitos da cidadania, constituindo fator de desigualdade em relação a estrangeiros. $\mathrm{Na}$ democracia contemporânea, não é mais possível negar aos estrangeiros os direitos de plena cidadania, mantendo a discriminação de que tradicionalmente são vítimas. Assim como a cidadania foi historicamente 
estendida aos não-proprietários, aos trabalhadores, às mulheres, aos jovens, não há razão para negar hoje sua extensão aos estrangeiros residentes no país (...) (2001,p.240)

\section{4. "Novas" cidadanias}

No universo jurídico, mas principalmente no campo das ciências sociais, há uma recorrência de discursos que afirmam o alargamento do significado de cidadania questionando a percepção usual de que cidadania tem relação apenas com direitos políticos em sentido estrito. Para dar um nome a esse fenômeno, é comum, na bibliografia, a referência ao advento de uma "nova" cidadania.

A "nova" cidadania expressa na literatura consultada não se traduz em um conceito teórico coincidente em todas as suas aparições, de tal sorte que há várias "novas cidadanias", de acordo, normalmente, com o realce que se queira dar para uma determinada gama de "novos" direitos.

Assim, José Alfredo de Oliveira Baracho (1995), autor que citamos quando discorremos sobre a noção jurídica de cidadania, indica que a nova cidadania não abarca apenas a participação política, mas os mecanismos de acesso ao Poder Judiciário e às garantias constitucionais do processo.

Flavia Piovesan, não se utiliza propriamente do adjetivo "nova" mais aponta para uma "redefinição da cidadania no Brasil" com base na tutela internacional dos direitos humanos onde o conceito de cidadania é alargado "na medida em que passa incluir não apenas direitos previstos no plano nacional, mas também direitos internacionalmente enunciados". (2003, p.72)

Nesses casos, podemos dizer que a "nova cidadania" se traduz sempre em uma forma de expressar o alargamento do sentido de cidadania em sua faceta de direitos. Mas há outras possibilidades de se enxergar a novidade na temática da cidadania. Como, por exemplo, a identificação "novos" atores no cenário político. Assim, Vera Silva Telles, ao escrever a introdução da publicação resultante do seminário de sugestivo título "novas faces da cidadania", justifica que:

No horizonte destes debates estão as esperanças- e possibilidades- de uma cidadania ampliada que incorpore sujeitos políticos até muitos recentemente excluídos da arena pública. Em torno dos direitos das mulheres, crianças, negros, 
populações indígenas e minorias discriminadas- são estes os personagens que compareceram como atores no seminário. ( 1996, p.1)

Para Fábio Konder Comparato, "a idéia-mestra da nova cidadania consiste em fazer com que o povo se torne parte principal do processo de seu desenvolvimento e promoção social: é a idéia de participação". (1993, p.92) (o primeiro grifo é nosso; o segundo do autor)

É evidente que a nomenclatura "nova cidadania" pode ser equívoca. Sem considerar a prosaica observação de que aquilo que é classificado como "novo" está sujeito a se deparar com o "novíssimo", abrindo espaço para outras formas de confusão no entendimento da noção, a expressão "nova cidadania" pode dar a entender que a novidade é um acréscimo de outras perspectivas ao sentido antigo sem excluí-lo, ou então, que esse novo modo de ver substitui a maneira antiga (ou deve substituí-la).

De maneira geral, podemos dizer que os novos sentidos de cidadania, ou a ampliação do seu significado, estão a serviço da: 1) atualização do sentido da noção em termos de conteúdo para abarcar novos direitos; 2) integração de atores sociais tradicionalmente excluídos do universo da cidadania, como as mulheres, negros, homossexuais, etc.

No primeiro caso, se considerarmos a tríade "cidadão-direitos-Estado" como uma espécie de constante a compor a noção de cidadania (pelo menos do ponto de vista da experiência lingüística, como vimos no item 3.1) o foco da expressão "nova" cidadania dirige-se a um alargamento da dimensão "direitos".

No segundo, o redimensionamento se dá em relação ao próprio “cidadão", ampliando a base numérica de incluídos na noção.

Mas de forma geral esses dois enfoques encontram-se inter-relacionados, se considerarmos que os movimentos de luta por igualdade e respeito no tocante a gênero e diferenças raciais, de proteção a crianças, idosos, deficientes, sem contar os movimentos ecológicos, entre outros, dão corpo e voz a diversas formas de pressionar e reivindicar direitos que até então não eram considerados pelo discurso dominante .

Assim é que Evelina Dagnino (1995) aponta para a existência de uma "nova cidadania" nas reivindicações dos diversos grupos tradicionalmente excluídos, negros, mulheres, homossexuais e outros, não só conquistando direitos previamente definidos, mas criando novos direitos, que surgem no bojo dessas mesmas lutas. 
Na tríade que estamos evocando, "cidadão-direitos-Estado", o pólo "cidadão" passa a ser qualificado com o nome do grupo do qual se faz parte; na verdade é por meio do grupo que se estabelece a relação dos cidadãos com o Estado.

\subsubsection{Cidadania Global}

É possível encontrar indicações de uma "nova" cidadania, substitutiva da concepção tradicional que necessita da noção de "Estado-nação" para se configurar, em favor de uma noção amplíssima que contemplaria a cidadania em um mundo globalizado, onde o Estado-nação vai perdendo lentamente a importância. (VIEIRA, 2001)

É curioso mencionar que o dicionário Aurélio a partir de sua $2^{\mathrm{a}}$ edição (1986) e também o dicionário Houaiss registram a idéia de "cidadão do mundo", onde a noção de Estado perde a importância. No Aurélio, o enunciado definidor é "homem que põe os interesses da humanidade acima dos da pátria”. No Houaiss, cidadão do mundo é o "indivíduo que coloca suas obrigações para com a humanidade acima dos interesses de seu país".

Essa noção não é novidade entre os sentidos que a história da palavra na língua portuguesa registrou $^{59}$, mas atualmente podemos dizer que é condizente com tempos de globalização já que diluí a idéia de Estado na composição do sentido de cidadania. A nosso ver, é uma concepção de cidadania, em muitas de suas formas de enunciação, mais de cunho moral do que jurídico e político, mais próxima de um ideal difuso de fraternidade do que dos ideais de liberdade e igualdade, que normalmente são os princípios-chave da cidadania.

De toda sorte, há uma reconfiguração concreta da cidadania em andamento na Comunidade Européia, por exemplo, em que a ligação do cidadão ao Estado nação tradicional convive com um vínculo que extrapola as fronteiras territoriais de um país.

Dessa forma, a tríade "cidadão-direitos-Estado" vai sendo alterada no pólo "Estado", para se encaminhar para uma cidadania global, ou mundial.

\footnotetext{
${ }^{59}$ Segundo OLIVEIRA (2006, p88) esse sentido já apareceu antes na história da língua portuguesa na obra de Frei Domingos Vieira, "Thesouro da Lingua Portugueza" de 1871, onde se lê "cidadão do mundo, cidadão do universo, homem que põe os interesses da humanidade acima da pátria" do mundo", correspondendo aos ideais universalistas do Iluminismo.
} 
Entretanto, o efeito pretensamente benéfico e generoso de uma cidadania mundial pode ser relativizado e para isso citamos a advertência de Hannah Arendt:

\begin{abstract}
Nossos conceitos políticos, segundo os quais temos de assumir responsabilidade por todos os assuntos públicos ao nosso alcance, independentemente de uma "culpa" pessoal, pois como cidadãos nos tornamos responsáveis por tudo o que nosso governo faz em nome do país, podem nos levar a uma situação intolerável de responsabilidade global. A solidariedade entre a humanidade pode muito bem se converter numa carga insuportável, e não surpreende que as reações habituais a isso sejam a apatia política, o nacionalismo isolacionista ou a rebelião desesperada contra todos os poderes, mais do que um entusiasmo ou desejo de fazer ressurgir o humanismo. (2008, p. 92-93)
\end{abstract}

\title{
3.4.2. "Empresa-cidadã"
}

As novidades no tocante à noção de cidadania que consideramos anteriormente referem-se a seres humanos, pessoas físicas, como titulares de um feixe ampliado de direitos ou participantes de uma ordem mundial cosmopolita ou territorialmente alargada.

Portanto, é curiosa, a acepção de cidadania ligada a ações de pessoas jurídicas, corporações privadas, normalmente com fins lucrativos. Retomando a observação que fizemos quando indicamos que em alguns momentos a Constituição de 1988 reserva à cidadania um sentido tão somente de eleitor, cumpre lembrar que a pessoa jurídica não pode ajuizar ação popular por não ser eleitora e, portanto por não ser propriamente cidadã em sentido estrito, o que é revelador do uso indiscriminado das palavras cidadania e cidadão em contextos não políticos como nos discursos corporativos contemporâneos, onde se firmou a idéia de "empresa-cidadã." A rigor, uma empresa pode ser nacional, mas só os indivíduos podem ser cidadãos. Em que medida, então, uma empresa seria "cidadã"? Ora, nesse caso podemos dizer que a tríade "cidadão-direitos-Estado" foi atingida no pólo do próprio "cidadão", enquanto uma pessoa humana, para dar lugar a corporações privadas. Só um uso alargado da palavra, em que parece sobressair-se uma idéia difusa de responsabilidade empresarial pode justificar essa acepção. A empresa é “cidadã" porque assumiria responsabilidades em relação à comunidade, além de meramente auferir lucros.

Essa responsabilidade social envolveria medidas que demonstram ou procuram demonstrar o alto grau de consciência social do empresariado e seus funcionários que ao 
realizarem as atividades econômicas que lhes são afetas, não deixariam de se preocupar com questões ecológicas, justiça social, distribuição de renda, etc.

Monica de Jesus Cesar em trabalho que procura dissecar o conceito de empresacidadã, localiza no tempo o fenômeno e nos oferece uma noção geral de responsabilidade social corporativa:

\begin{abstract}
No decorrer dos anos 1990, a idéia da "responsabilidade social corporativa" ganhou consistência no meio empresarial, sendo traduzida como o conjunto de atividades que a empresa realiza para atender, internamente, às necessidades dos seus empregados e dependentes e, externamente, às demandas das comunidades, em termos de assistência social, alimentação, saúde, educação, preservação do meio ambiente, e desenvolvimento comunitário, entre outras. (CESAR, 2008, p. 18)
\end{abstract}

Evidentemente que a "cidadania corporativa" apresenta grande ambigüidade, na medida em que se pode selecionar as "condutas cidadãs" a serem desempenhadas com base em critérios de retorno, como por exemplo, a criação de uma imagem positiva da própria corporação no mercado e parece razoável supor que dificilmente tais escolhas se submeterão a decisões políticas ampliadas que não se coadunem aos interesses diretos ou indiretos de lucratividade da corporação.

\title{
3.4.3. Cidadania, organizações não-governamentais e filantropia
}

O “terceiro setor", ou seja, uma esfera que não seria vinculada ao governo e nem ao setor produtivo de mercado, representado pelas Organizações não governamentais trouxe mais fortemente na última década do século XX, “ novas possibilidades para o exercício da cidadania $^{60}$,

Assim, como exemplo, lembramos que a Editora Abril publicou em 2001 o chamado "Guia da Cidadania", com a intenção de fornecer informações sobre o exercício da cidadania.

No aludido Guia há uma seção destinada a apresentar o papel das organizações não governamentais na construção da cidadania. Essa seção é iniciada com um artigo

\footnotetext{
${ }^{60}$ A citação reproduz o título de um artigo que se destina a comentar a relação entre o Terceiro Setor e cidadania (NAVES, 2008)
} 
denominado "O manual da cidadania" cujo conteúdo visa incentivar as pessoas a realizarem trabalho voluntário.

Logo em seguida, é apresentada uma lista em ordem alfabética de duzentas organizações não-governamentais que poderiam ser escolhidas pelos interessados no voluntariado, ou melhor, em exercer cidadania, pois há uma sinonímia no uso dessas expressões. Ora, esse rol, segundo informação do próprio Guia, foi elaborada a partir do Guia da Filantropia de Stephen Kanitz que lista as quatrocentas maiores entidades beneficentes do país.

Cidadania é então, nesse contexto, o nome dado a generosidade de voluntários canalizada através de entidades privadas sem fins lucrativos já que "com a falência do Estado, atolado em dívidas, juros e déficits, como a da Previdência, sobram cada vez menos recursos para a área social e aumentam assustadoramente os problemas sociais". (ALMANAQUE ABRIL: Guia da Cidadania, 2001, p.74)

\footnotetext{
Curiosamente, a cidadania precisa ser espontânea. Um profissional social contratado pelo governo, por um baixo salário mensal, nem sempre desprende o mesmo amor e carinho que um voluntário. Resgatar nossa cidadania perdida será o grande desafio brasileiro para os próximos dez anos.(ALMANAQUE ABRIL: Guia da Cidadania, 2001, p.75)
}

Cidadania, segundo essa visão, precisaria de "espontaneidade", uma naturalidade não profissional, aparentada a sentimentos como a boa vontade entre os homens, de grande valor e nobreza, mas nos parece que aí há um limite conceitual transposto que gera uma mistura envolvendo cidadania e filantropia.

A filantropia é da ordem das decisões privadas que não precisam necessariamente de luz pública, aliás nem seria desejável que condutas dessa natureza ganhassem publicidade. A cidadania é da ordem política e só tem sentido em ambiente público, onde se presume a convivência de iguais.

O compromisso da filantropia não é marcado necessariamente pela busca da igualdade, um dos valores- chave que move o exercício da cidadania. Os atos filantrópicos podem deixar entrevisto o desequilíbrio que revela uma certa superioridade daquele que oferece ajuda (uma vez que lhe sobram condições) em relação àquele que é beneficiado.

A nossa tríade "cidadão-direitos-Estado", nesse caso, é totalmente desmobilizada na medida em que há um esvaziamento total da natureza política da relação, sendo o cidadão transmutado em um benfeitor privado que nada espera das decisões de natureza 
política, pelo menos das instâncias formais, já que parte da consideração da "falência do Estado".

\subsubsection{A pulverização de designações}

Uma das maiores perplexidades com a qual nos deparamos ao estudar a noção de cidadania, é a miríade de adjetivos que o termo recebe. Esse processo, longe de contribuir para trazer mais clareza, vai fragmentando a noção de cidadania em várias subnoções, às vezes até inconciliáveis entre si.

Nesse sentido, atentemos para a maior complexidade que a idéia de cidadania vai adquirindo, a partir da teoria de Marshall.

$\mathrm{Na}$ medida em que o modelo de Marshall, ao mencionar que os elementos ou direitos da cidadania são os direitos civis, políticos e sociais, abriu espaço para o uso de sub-noções complementares, cada qual correspondente a um feixe de direitos, adjetivadas como "cidadania civil", "cidadania política" e "cidadania social", como se existissem três cidadanias diferentes.

O próprio Marshall não faz uso desse tipo de distinção adjetivada; apenas descreve a ampliação do conteúdo da cidadania por meio da incorporação sucessiva das três modalidades de direitos, conforme vimos.

A adjetivação às vezes pode causar curiosas redundâncias. Por exemplo, sobre o uso comum da expressão "cidadania política", Michelângelo Bovero observa que é "uma expressão que em grego se revelaria perfeitamente pleonástica, como polites polítikos." (2002, p. 120). Soaria, talvez, como se disséssemos "cidadania cidadã".

Trabalhos sobre a temática da cidadania, naturalmente, fazem uso dessas adjetivações, como podemos observar em dois títulos recentes: “A questão da evolução da cidadania política no Brasil" (SAES, 2001) (grifo nosso) ou "A cidadania social na Constituição de 1988”. (NUNES JÚNIOR, 2009) (grifo nosso)

É claro que, normalmente, a finalidade é destacar uma das esferas que comporiam a cidadania em seu sentido integral, mas é inegável que a inflação de designações adjetivadas contribui para entendimentos parciais do sentido de cidadania.

O panorama fica mais complexo se mencionarmos que as demandas por inclusão social de grupos historicamente desfavorecidos acarretou a cunhagem de expressões como 
"cidadania homossexual" "cidadania da mulher", "cidadania do deficiente", "cidadania do negro", "cidadania indígena" "cidadania ambiental" etc, dando a entender que cidadania não é um conceito unificador, mas pulverizável em acepções conformadas às especificidades de cada grupo.

As diversas "novas" cidadanias, as inúmeras cidadanias coletivas que recebem uma qualificação correspondente ao grupo envolvido (e que inflacionam o universo de designações para muito além das subnoções que foram indicadas a partir do trabalho de Marshall) contribuem para um quadro confuso e flutuante de sentidos.

Para nós, que estamos interessados em discutir o sentido de cidadania condizente com o objetivo constitucional de educar para a cidadania, a que sentido devemos nos apegar diante desse universo de cidadanias plurais?

Acreditamos que sem desvalorizar as lutas que justificam uma grande parte desses qualificativos (em especial no tocante aos grupos minoritários), talvez valha compartilhar da posição de Elisa Reis no tocante ao fracionamento de designações de cidadania. A autora, em um contexto de debate sobre a cidadania do trabalhador rural, expressa-se da seguinte forma:

Tem sentido falar numa cidadania camponesa? Seria válido fragmentar esse conceito de cidadão para falar de uma cidadania operária, camponesa, feminina, étnica ou o que seja? Prefiro não fragmentar a cidadania, porque a condição da igualdade é a sua generalidade, a universalização do conceito. (1986, p.55)

Para os nossos fins, também preferimos não fragmentar a cidadania.

Darcísio Corrrêa sugere que "para que se possa fazer uma conceituação mais clara de cidadania, e que não se confunda simplesmente com a noção de direitos humanos, é preciso deixar de abordá-la de forma exclusivamente adjetivada”. (2006, p.217)

É necessário que nos detenhamos mais especificamente no sentido dado à cidadania enquanto objeto da educação, na Constituição Federal de 1988. Sendo assim, dando por encerrada a tarefa de apresentar as dificuldades impostas para o estabelecimento da noção de cidadania, será preciso direcionar o nosso enfoque ao sentido constitucional de preparar para o exercício da cidadania. E esse sentido, a nosso ver, não representaria propriamente uma "nova" cidadania, mas a retomada da idéia básica de participação política. 


\section{CIDADANIA E EDUCAÇÃO EM UM CONTEXTO DE DECLÍNIO DA POLÍTICA NO MUNDO CONTEMPORÂNEO}

Neste capítulo, vamos nos valer de algumas perspectivas de análise da pensadora Hannah Arendt, mas apenas na medida em que possam contribuir para uma melhor visualização dos problemas mais gerais que afetam a percepção do que seja cidadania e suas repercussões na educação que se pretende preparatória para o exercício da cidadania, sem que seja a nossa pretensão uma discussão teórica profunda da obra da autora.

\subsection{A vitória do consumidor sobre o cidadão}

Quando discorremos, no capítulo anterior, sobre o surgimento da noção de cidadania na Antigüidade, indicamos as características gerais da polis, frisando a radicalidade da separação entre a esfera pública e a esfera privada.

A dicotomia entre a luminosidade pública e a obscuridade do mundo privado, tensão que é uma das características marcantes da configuração da polis, é evocada por Hannah Arendt, principalmente na obra A Condição Humana, para registrar o surgimento da política no Ocidente e usada como um ponto de partida fundamental para entender o declínio da experiência política na Era Moderna.

A atividade política, que representaria a mais alta excelência do homem, diferenciando-o das outras espécies animais, na era moderna é suplantada em importância pelos imperativos da necessidade de consumo, originalmente (na experiência da polis) relegados ao ocultamento na privatividade do lar. Essa expressão pública de assuntos privados, ou a dissolução da demarcação entre o público e o privado, dá forma, segundo Arendt, a uma esfera desconhecida na Antigüidade: a esfera social.

A "arqueologia" que Arendt desenvolve em sua obra, muitas vezes mal interpretada, como se a autora fosse uma saudosista da Antigüidade greco-romana, oferece uma chave para a compreensão de acontecimentos marcantes do século XX, como a ascensão dos sistemas totalitários e o triunfo da sociedade massificada de consumo, para os quais contribuiu a degradação do espaço público, ou mais propriamente o declínio da esfera política da existência humana. 
Em A Condição Humana, Arendt apresenta e discute os elementos que condicionam a existência humana (a vida, a natalidade e a mortalidade, a mundanidade, a pluralidade e o planeta Terra), três das atividades que os seres humanos realizam em resposta a esses condicionamentos (labor, fabricação e ação) e os espaços onde essas atividades se realizam (esfera pública, esfera privada e, modernamente, a esfera social).

No prólogo de A Condição Humana, Arendt anuncia que irá refletir sobre as atividades às quais os seres humanos se dedicam:

\footnotetext{
"O que estamos fazendo" é, na verdade, o tema central deste livro, que aborda somente as manifestações mais elementares da condição humana, aquelas atividades que tradicionalmente, e também segundo a opinião corrente, estão ao alcance de todo ser humano. (ARENDT, 2005a, p.13)
}

Arendt nomeia essas atividades, no texto original em inglês, como labor (labor), work (fabricação) $e$ action (ação) ${ }^{61}$.

Labor é a atividade humana que responde à necessidade natural de manutenção da vida, não só do indivíduo como também da espécie. Trata-se de uma atividade cíclica, biologicamente obrigatória e que não obedece aos caprichos da vontade. A rotina de manutenção de uma casa é um exemplo possível do labor.

É preciso preparar as refeições todos os dias, pois comer é uma necessidade constante e jamais satisfeita de uma vez por todas. Esse alimento é metabolizado pelo corpo, transformado em compostos nutrientes para a manutenção da vida, e é em parte excretado, retornado ao ambiente, em uma retomada da trajetória circular da matéria orgânica na natureza. E o corpo, por sua vez, passado o estágio da saciedade, mais uma vez exigirá uma nova refeição, em um ciclo que só termina com a morte, embora mesmo aí, outro ciclo continua com a devolução da matéria constitutiva do corpo à natureza.

\footnotetext{
${ }^{61}$ Aqui é preciso apontar que há um problema de transposição dessa nomenclatura para o português no tocante aos termos labor e work. A versão em língua portuguesa da obra A condição Humana (2005 a) de responsabilidade do tradutor Roberto Raposo e que utilizamos como base nesse estudo, traduz labor pela palavra portuguesa de mesma grafia "labor",a palavra work é traduzida por "trabalho" e action é traduzida por "ação". Alguns autores especialistas na obra da autora, como André Duarte (2000) traduz a tríade "labor, work e action" , respectivamente como "trabalho, fabricação e ação". Com base nas traduções disponíveis, utilizaremos a palavra labor para designar labor, fabricação para designar work e a ação para designar action, no decorrer desse estudo.
} 
O ser humano não se diferencia dos outros animais pelo labor. Daí porque o homem em sua dedicação ao labor é identificado por Arendt como animal laborans, e não homo laborans.

Nas palavras de Arendt

\begin{abstract}
E a verdade é que o emprego da palavra "animal" no conceito de animal laborans, ao contrário do outro uso, muito discutível, da mesma palavra na expressão animal rationale, é inteiramente justificado. O animal laborans é, realmente, apenas uma das espécies animais que vivem na terra- na melhor das hipóteses a mais desenvolvida. (2007, p.95)
\end{abstract}

A atividade do labor retrata o ser humano em suas condições vitais mais básicas colocando-o em pé de igualdade a outros seres vivos na luta pela sobrevivência.

Para nós, seres humanos, organizados em estruturas civilizacionais, a atividade de labor também possui conotações um pouco menos cruamente biológicas e animalescas, mas também cíclicas e necessárias à vida. É preciso, por exemplo, lavar as louças sujas na produção e no consumo dos alimentos, todos os dias ou pelo menos periodicamente. É preciso limpar a casa, arrumar as camas após as noites de sono, dar um destino ao lixo produzido, em uma monotonia cíclica, persistente e necessária.

O labor é uma atividade que não produz nada destinado a durar permanentemente, não se expressa em uma materialidade perene pois o destino de seu produto é o desaparecimento sem deixar vestígios nas tramas da manutenção da vida. São esforços humanos que longe de serem expressão da autonomia humana, dissolvem-se como se fossem parte dos movimentos da própria natureza em sua necessidade de perpetuação.

A fabricação (work) é a atividade humana que transforma a matéria-prima fornecida pela natureza em algo não ligado às necessidades do metabolismo da vida biológica, de forma a produzir artefatos com durabilidade, para o uso humano.

$\mathrm{Na}$ atividade de fabricação, a autonomia do homem está presente domesticando a natureza, agindo sobre e contra a natureza para produzir algo durável com o feitio humano para o mundo humano. Aqui é o homem que subjuga a natureza.

O marceneiro que entalhou a mesa onde se dá as refeições produzidas pelo labor, realiza a atividade de fabricação. 
Os artefatos utilizados na manutenção da rotina de uma casa (mesa, vassoura, roupa de cama, louças etc.) são frutos da fabricação, pois não são consumidos no ciclo vital, e o seu desgaste se dá pelo uso e não pelo consumo.

A atividade do fabricante (homo faber) e o "seu produto, o artefato humano, emprestam certa permanência e durabilidade à futilidade da vida mortal e ao caráter efêmero do tempo humano". (ARENDT, 2005a, p.16) .

Há um vínculo marcante entre a fabricação e o mundo, conceito que, para Hannah Arendt, não se remete a uma categoria geográfica ou natural, como se fosse outra forma de se referir ao planeta Terra. Trata-se de um conceito-chave em sua obra e se refere ao conjunto geral de toda a artificialidade criada pelos homens que dá forma ao que de fato é humano e que se compõe das construções, artefatos, de maneira geral, mas também de bens simbólicos, a História, o idioma etc, que são compartilhados pelos seres humanos. Assim, não deve soar estranho se disséssemos que os animais não vivem no mundo, pois como diz Arendt, "o mundo- artifício humano- separa a existência do homem de todo o ambiente meramente animal”. (2005 a, p.10)

Segundo a autora,

\begin{abstract}
O mundo comum é aquilo que adentramos ao nascer e que deixamos para trás quando morremos. Transcende a duração de nossa vida tanto no passado quanto no futuro: preexistia à nossa chegada e sobreviverá à nossa breve permanência. É isto que temos em comum não só com aqueles que vivem conosco, mas também com aqueles que aqui estiveram antes e aqueles que virão depois de nós. Mas esse mundo comum só pode sobreviver ao advento e à partida das gerações na medida em que tem uma presença pública. É o caráter público da esfera pública que é capaz de absorver e dar brilho através dos séculos a tudo o que os homens venham a preservar da ruína natural do tempo. Durante muitas eras antes de nósmas já não agora- os homens ingressavam na esfera pública por desejarem que algo seu, ou algo que tinham em comum com outros, fosse mais permanente que as suas vidas terrenas. (2005 a, p.65)
\end{abstract}

O homem fabrica o mundo e é por ele condicionado daí porque a mundanidade é uma das condições de existência do homem: "o que quer que toque a vida humana ou entre em duradoura relação com ela, assume imediatamente o caráter de condição da existência humana." (ARENDT, 2005 a p.17).

A fabricação é regida pela lógica dos meios e fins, possui um itinerário definido que se desenvolve até o término da obra, de forma que, segundo Arendt,

A característica da fabricação é ter um começo definido e um fim definido e previsível, e esta característica é bastante para distingui-la de todas as outras atividades humanas. O labor, preso à engrenagem do movimento cíclico do 
processo vital do corpo, não tem começo nem fim. E, como veremos adiante, a ação, embora tenha um começo definido, jamais tem um fim previsível" ( ARENDT, 2005 a, p. 156)1

A ação é a atividade humana que não está ligada à circularidade monótona da manutenção da vida e nem à previsibilidade da fabricação, mas à possibilidade de iniciar algo novo e inesperado, pois está "intimamente relacionada com a condição humana da natalidade; o novo começo inerente a cada nascimento pode fazer-se sentir no mundo somente porque o recém-chegado possui a capacidade de iniciar algo novo, isto é, de agir". (ARENDT, 2005 a, p.17)

Cada novo ser humano carrega em si o gérmen da novidade, a possibilidade de iniciar o inesperado e a ação é a atividade humana que tem o poder de veicular essa potencialidade.

Na obra, Sobre a Violência, Arendt diz:

\begin{abstract}
O que faz do homem um ser político é sua faculdade para a ação; ela o capacita a reunir com seus pares, a agir em concerto e a almejar objetivos e empreendimentos que jamais passariam por sua mente, para não falar nos desejos de seu coração, se a ele não tivesse sido concedido esse dom- o de aventurar-se em algo novo. Filosoficamente falando, agir é a resposta humana para a condição da natalidade. (ARENDT, 2009, p. 102)
\end{abstract}

Note-se que natalidade tem um sentido específico na obra de Arendt e está ligado ao nascimento em um mundo composto de artefatos, bens simbólicos e realizações preexistentes e não meramente ao nascimento biológico enquanto espécie animal.

A ação oferece uma resposta à condição humana da pluralidade, que se caracteriza pelo fato de que esse mundo é habitado por diferentes seres humanos que precisam conviver, planejar, organizar a vida comum. "A pluralidade é a condição da ação humana pelo fato de sermos todos os mesmos, isto é, humanos, sem que ninguém seja exatamente igual a qualquer pessoa que tenha existido, exista ou venha a existir." (ARENDT, 2005a, p.16)

A pluralidade lida com uma dialética entre a igualdade e diferença:

Pluralidade humana, condição básica da ação e do discurso, tem o duplo aspecto de igualdade e diferença. Se não fossem iguais, os homens seriam incapazes de compreenderem-se entre si e aos seus ancestrais, ou de fazer planos para o futuro e prever as necessidades das gerações vindouras. Se não fossem diferentes, se cada ser humano não diferisse de todos os que existiram, existem ou virão a existir, os homens não precisariam do discurso ou da ação para se fazerem 
entender. Com simples sinais e sons poderiam comunicar suas necessidades imediatas e idênticas"(ARENDT, 2005a, p.188).

A imprevisibilidade da ação, característica que é a essência da atividade política (afinal o novo em seu ineditismo e frescor, não poderia ser novidade se pudesse ser previsto), sempre teve contra si a desconfiança de muitos que se dedicaram ao pensamento político, motivo pelo qual são comuns esforços no sentido da domesticação do que é político para ajustar-se na lógica da fabricação, cujo resultado é previsível, como se atividade política se restringisse à administração burocrática de meios para a obtenção de resultados esperados.

A noção da perda de controle sobre os processos que são iniciados pela ação está expresso de forma poética por Guimarães Rosa no seguinte trecho de Grande Sertão Veredas: "a gente principia as coisas, no não saber por que, e desde aí perde o poder de continuação- porque a vida é mutirão de todos, por todos remexida e temperada" (1995, p.293)

Note-se que nesse trecho temos a presença do poder de iniciar o novo, mas também uma referência à pluralidade humana, sem a qual não existe a atividade política. É possível imaginar o labor e a fabricação sendo realizados sem a presença de outros, mas a ação exige ambiente público, a visibilidade e o discurso.

Podemos dizer que a ação possui expressão na figura-símbolo do cidadão, enquanto a fabricação se expressa na figura do produtor ou fabricante e o labor na figura do consumidor.

A hierarquia entre essas atividades, no sentido do maior ou menor valor atribuído cada uma delas, sofre uma inversão e vai da excelência atribuída ao modo de vida do cidadão na polis à moderna preponderância do operário-consumidor.

Essas três atividades humanas elementares correlacionam-se com as esferas pública e privada, ficando evidenciado que a ação é a atividade para a qual o espaço público é imprescindível, enquanto as atividades do labor e fabricação podem se dar sem luz pública.

Como já havíamos apontado quando tratamos da cidadania Antiga, a esfera pública é o espaço próprio do cidadão onde se discute aos olhos de todos os assuntos que são relevantes para toda a comunidade, enquanto a esfera privada é reservada aos assuntos da rotina de sobrevivência da família. A partir da era moderna a marcação nítida desses espaços vai perdendo os contornos definidos, dissolvendo-se em uma esfera híbrida 
chamada de sociedade, esfera desconhecida dos antigos, em que cada vez mais os assuntos privados passam a ter relevância pública. Nas palavras de Arendt:

\begin{abstract}
A distinção entre uma esfera de vida privada e uma esfera de vida pública corresponde à existência das esferas da família e da política como entidades diferentes e separadas, pelo menos desde o surgimento da antiga cidadã-estado; mas a ascendência da esfera social, que não era privada nem pública no sentido restrito do termo, é um fenômeno relativamente novo, cuja origem coincidiu com o surgimento da era moderna(...) (2005a, p.37)
\end{abstract}

A ocupação do espaço reservado outrora à política, por assuntos ligados mais diretamente à sobrevivência do homem ou à atividade do labor, é assim descrito pela autora:

\begin{abstract}
A mais clara indicação de que a sociedade constitui a organização pública do próprio processo vital talvez seja encontrada no fato de que, em tempo relativamente curto, a nova esfera social transformou todas a comunidades modernas em sociedades de operários e de assalariados; em outras palavras, essas comunidades concentraram-se imediatamente em torno da única atividade necessária para manter a vida- o labor. (2005a, p.56)
\end{abstract}

A esfera pública, originalmente, não tinha compromisso algum com a manutenção da vida, já que "nenhuma atividade que servisse à mera finalidade de garantir o sustento do indivíduo, de somente alimentar o processo vital, era digna de adentrar a esfera política". (ARENDT, 2005 a p. 46)

Por isso, diz Arendt que:

Deixar a família, originalmente para abraçar alguma empresa aventureira e gloriosa, e mais tarde simplesmente para dedicar a vida aos negócios da cidade, exigia coragem, pois era só no lar que o homem se empenhava basicamente em defender a vida e a sobrevivência. Quem quer que ingressasse na esfera política deveria, em primeiro lugar, estar disposto a arriscar a própria vida; o excessivo amor à vida era um obstáculo à liberdade e sinal inconfundível de servilismo. (2005 a. p. 45)

Evidentemente que é preciso haver a garantia da satisfação das necessidades básicas sem as quais não é possível espécie alguma de vida, "a política, porém, jamais visa a manutenção da vida." (2005a, p.47)

A vitória do animal laborans como forma de vida predominante na Era Moderna, implica que o consumo acelerado sobrepõe-se à fabricação e coloca em risco a estabilidade e durabilidade do mundo: 
Em nossa necessidade de substituir cada vê mais depressa as coisas mundanas que nos rodeiam, já não podemos nos dar ao luxo de usá-las, de respeitar e preservar sua inerente durabilidade; termos que consumir, devorar, por assim dizer, nossas casas, nossos móveis, nossos carros, como se estes fossem as "boas coisas" da natureza que se deteriorariam se não fossem logo trazidas para o ciclo infindável do metabolismo do homem com a natureza.. É como se houvéssemos derrubado as fronteiras que distinguiam e protegiam o mundo, o artifício humano, da natureza, do processo biológico que continua a processar-se dentro dele, bem como os processos cíclicos e naturais que o rodeiam, entregando-lhes e abandonando a eles a já ameaçada estabilidade do mundo humano. (2005 a p. 138)

Esse triunfo de uma mentalidade de consumidor, preocupada acima de tudo com a subsistência contribui para uma forma de vida ensimesmada acarretando uma desarticulação das potencialidades inerentes à ação política, dada a atomização, isolamento ou alheamento dos cidadãos em relação às questões de interesse público.

Nesse sentido, Arendt faz a seguinte observação sobre o afastamento geral dos cidadãos da esfera pública a partir da Era Moderna: "a sociedade competitiva de consumo criada pela burguesia gerou apatia, e até mesmo hostilidade, em relação à vida pública, não apenas entre as camadas sociais exploradas e excluídas da participação ativa no governo do país, mas acima de tudo entre a sua própria classe”. (2007, p.363)

\subsection{A dissolução do senso comum}

A extrema confusão que envolve o significado de cidadania, conforme procuramos demonstrar no capítulo anterior, a impossibilidade de fixarmos um entendimento comum sobre o termo é apenas um sintoma de uma crise mais abrangente, que vem, segundo Arendt, se desenvolvendo desde o início da modernidade, e que se expressa claramente no declínio da política e de uma suas qualidades mais importantes: o senso comum.

No prólogo da obra A Condição Humana, comentando as dificuldades cada vez maiores de comunicação e entendimento sobre as conquistas científicas no campo da Física do século XX, Arendt faz um comentário mais geral no sentido de que habitamos um mundo "no qual as palavras perderam o seu poder".

Diz à autora que:

Haverá talvez verdades que ficam além da linguagem e que podem ser de grande relevância para o homem no singular, isto é, para o homem que, seja o que for, não é um ser político. Mas os homens no plural, isto é, os homens que vivem e se 
movem e agem neste mundo, só podem experimentar o significado das coisas por poderem falar e ser inteligíveis entre si e consigo mesmos. (2005a. p. 12)

O compartilhamento do mundo expressa-se no senso comum, conforme as palavras de Arendt:

\begin{abstract}
O único atributo do mundo que nos permite avaliar sua realidade é o fato de ser comum a todos nós; e, se o senso comum tem posição tão alta na hierarquia das qualidades políticas, é que é o único fator que ajusta à realidade global os nossos sentidos estritamente individuais e os dados estritamente particulares que eles registram, Graças ao senso comum, é possível saber que as outras percepções sensoriais mostram a realidade, e não são meras irritações de nossos nervos nem sensações de reação de nosso corpo. Em qualquer comunidade, portanto, o declínio perceptível do senso comum e o visível recrudescimento da superstição e da credulidade constituem sinais inconfundíveis de alienação em relação ao mundo" (2005a,p. 221)
\end{abstract}

A idéia de senso comum enquanto um ajustamento das percepções do indivíduo ao que é comum a todos, que é a noção que Arendt privilegia, sofreu uma modificação na modernidade. $\mathrm{Na}$ progressiva ausência de experiências, princípios e práticas compartilhadas num mundo comum, a filosofia passa a conceber como o elo comum entre os homens a razão como dispositivo interior: "uma faculdade interior sem qualquer relação com o mundo. (...) o que os homens têm agora em comum não é o mundo, mas a estrutura da mente (...) (2005a, p.296)

A expressão "senso comum" é assimilada modernamente ao "bom senso" ou estrutura racional que todos os indivíduos teriam, cuja configuração encontramos nas conhecidas palavras iniciais de Descartes na abertura do Discurso do Método:

\footnotetext{
O bom senso é a coisa do mundo melhor partilhada, pois cada qual pensa estar tão bem provido dele, que mesmo os que são mais difíceis de contentar em qualquer outra coisa não costumam desejar tê-lo mais do que o têm . E não é inverossímil que todos se enganem a tal respeito; mas isso antes testemunha que o poder de bem julgar e distinguir o verdadeiro do falso, que é propriamente o que se denomina o bom senso ou a razão, é naturalmente igual em todos os homens (...) (1992, p. 29)
}

Assim, os significados diversos de cidadania que indicamos, alguns até antagônicos, inserem-se em uma diluição mais geral de significados, fruto da falta de senso comum na experiência compartilhada do mundo, exemplos que confirmam a aguda observação de Hannah Arendt no sentido de que "qualquer coisa pode, eventualmente, ser chamada de qualquer outra coisa, e de que as distinções somente têm significado na 
medida em que cada um de nós tem o direito de 'definir seus termos"'. (ARENDT, 2005b, p.132)

\subsection{A perda do sentido público da educação}

A educação é a resposta humana à natalidade, ou seja, ao fato de que os seres humanos quando nascem, são novos em um mundo repleto de significações que lhes são desconhecidas e precisam aprender sobre elas com aqueles que são mais velhos.

O significado público da educação enquanto acolhimento dos jovens em um mundo que lhes é preexistente, passa pelo aprendizado da herança cultural comum, sem o que a capacidade de renovação que está latente naqueles que são novos, é impossível.

De acordo com José Sérgio Fonseca de Carvalho :

\footnotetext{
O acolhimento dos novos no mundo pressupõe, pois, um duplo e paradoxal compromisso por parte do professor. Por um lado, cabe-lhe zelar pela durabilidade do mundo de heranças simbólicas no qual ele inicia e acolhe seus alunos, Por outro, cabe-lhe cuidar para que os novos possam se inteirar, integrar, fruir e, sobretudo, renovar essa herança pública que lhes pertence por direito mas cujo acesso só lhe é possível por meio da educação. (2008, p.266)
}

Com a interpenetração entre as esferas pública e privada, conforme passa a haver uma dificuldade de clareza nos critérios de definição do que seriam os aspectos públicos a serem privilegiados pela educação, de tal sorte que ganham relevo as preocupações privadas ligadas às necessidades da vida. Basta que mencionemos como exemplos, o grande destaque dado a uma formação educacional que vise à obtenção de êxito nos vestibulares mais concorridos e o preparo para o trabalho.

Como sabemos a qualificação para o trabalho é também uma das finalidades da educação conforme o art. 205 da Constituição de 1988. Entretanto, é notória a absoluta preponderância dada ao aspecto êxito profissional no processo educativo, em um viés competitivo que acompanha o aluno desde o ensino fundamental, ou até antes.

O problema do desemprego juvenil leva a propostas de ampliação de formatos educacionais mais diretamente voltados para o mercado, e menos vinculados à formação dos alunos em virtudes públicas, como o ensino médio técnico, educação à distância e os cursos superiores de curta duração ou de formação de tecnólogos, cujo sucesso nos últimos anos é louvado por setores da imprensa e pelos órgãos oficiais de Educação. 
$\mathrm{Na}$ verdade, trata-se de uma ênfase geral no sucesso econômico do indivíduo, mais do que uma preocupação com o papel desse indivíduo como cidadão, embora tais interesses privados recebam, não raro, o nome de "cidadania".

No Estado de São Paulo, podemos exemplificar a repercussão pública de aspectos estritamente privados, por meio de dois projetos de lei.

Trata-se do projeto de lei 604/2007 que determina a inclusão de aulas de "empreendedorismo" no conteúdo curricular das disciplinas de ciências humanas das escolas da rede estadual de ensino e do projeto de lei 834/ 2007 que incluí no currículo da rede pública estadual, a disciplina de "educação financeira"62.

$\mathrm{O}$ art. $2^{\text {o }}$, do projeto 604/2007 prevê que: “entende-se por Empreendedorismo o aprendizado pessoal que, impulsionado pela motivação, criatividade e iniciativa, capacita para a descoberta vocacional, a percepção de oportunidades e a construção de um projeto de vida."

Na justificativa ${ }^{63}$ que acompanha o projeto lemos que:

A inclusão do Empreendedorismo nas escolas tem como objetivo inserir os alunos em uma cultura empreendedora, a partir do conceito de sustentabilidade e crescimento. A idéia é torná-los críticos e preparados para a descoberta de vocações, com criatividade e técnicas motivacionais que auxiliem no desenvolvimento de capacidades e habilidades individuais.

\footnotetext{
${ }^{62}$ Os projetos de lei podem ser acessados no sítio da Assembléia Legislativa de São Paulo em <http://www.al.sp.gov.br/portal/site/Internet>

${ }^{63}$ Reproduzimos mais alguns trechos da justificativa desse projeto, pois são bastante ilustrativos do enfoque pouco integrado a virtudes públicas:

“(...) a capacitação profissional é um tema ainda distante da realidade da sala de aula. São raras as oportunidades para desenvolver a matéria no decorrer da jornada escolar. Como conseqüência, o aluno deixa os bancos escolares em meio a incertezas sobre o seu futuro profissional. E sem ao menos desenvolver todas suas habilidades e competências que lhe ajudarão na superação dos desafios na busca do primeiro emprego. (...)

O despreparo, aliado à desinformação, faz com que os estudantes alimentem dúvidas sobre o projeto futuro, que não se limita à escolha da profissão que pretendem exercer após a conclusão dos estudos. Muitos sonham vencer na vida, mas ignoram o caminho que precisam percorrer.

Diante desse quadro de incertezas, o Empreendedorismo torna-se uma ferramenta relevante para a formação do educando. Possibilita o elo entre a educação formal e o mundo do trabalho, desenvolvendo, nos alunos, a autonomia para a tomada de decisões, definição de planos e a criação de oportunidades.

(...)

Isoladamente, algumas escolas já despertaram para essa realidade. Conforme reportagem da revista Nova Escola, unidades municipais de São José dos Campos (SP) e de Belo Horizonte (MG) desenvolvem o Empreendedorismo no currículo escolar. Uma ação pioneira feita em parceria com a iniciativa privada, para capacitar professores em aulas sobre o tema.

Hoje, cada vez mais o jovem precisa assimilar os ensinamentos do Empreendedorismo para transpor as inúmeras barreiras impostas pela alta competitividade. A missão da escola não se limita à inserção do aluno no mercado de trabalho, mas capacitá-lo para encarar os desafios de forma equilibrada e sustentável.
} 
Ainda segundo a justificativa do projeto, "empreendedor é, acima de tudo, um cidadão que usa da criatividade e da motivação para superar os desafios que a vida impõe." (grifo nosso)

Note-se que, por esse prisma, o "empreendedor" é o "cidadão" dotado de certos atributos pessoais, mas a conjugação dessas duas facetas do indivíduo configura-se confusa e conflitante, porque, por um lado as virtudes esperadas do cidadão são de natureza pública, envolvem o convívio plural, tolerância, cooperação e de outro, o ideal de formação "empreendedora", implica, em alguma medida a valorização da competição de tal sorte que, as palavras de Katarina Tomasevski nos parecem muito apropriadas:

\footnotetext{
É impossível para as crianças aprenderem a competir e a cooperar ao mesmo tempo. Se elas competem umas contra as outras por melhores resultados e maiores notas, é sinal de que em suas escolas e em seus países cooperação permanece uma noção abstrata, e crianças aprendem com base em exemplos concretos, e não por discursos.( 2006, p.78)
}

A justificativa para o inserção de "Educação Financeira" no currículo da rede estadual, segundo o projeto 834/2007, também seria de natureza privada: “orientar os alunos sobre a montagem de um planejamento das finanças pessoais de modo sustentável."

Nas transformações da relação entre público e privado, a própria educação torna-se um bem de consumo, uma atividade mercantil que pode ser comparada ao produtivismo empresarial planejado e massificado sem nenhuma consideração sobre o compromisso da educação com a integridade daquilo que é único em cada ser humano, ou seja, a sua singularidade.

A mercantilização da educação já está tão naturalizada que quaisquer comentários críticos à visão empresarial da escola, como a transformação dos alunos em clientes, por exemplo, soam como obscurantistas e primitivos, objeto de ironia condescendente como é o caso de Claudio de Moura Castro, ao comentar que nas denúncias que criticam a educação como mercadoria, "as palavras são usadas como tacapes, na esperança de abater os infiéis". (2008, p.20).

O autor, que é estudioso da relação entre Educação e Economia, não vê o menor problema em tratar a atividade escolar com os mesmos critérios de produtividade empresarial: 
ensino para poucos? Ou para muitos? Ensino de violino? Uma vez definido o produto, faz todo o sentido obter o máximo resultado com o mínio de gastos. Isso vale na "fabricação" de hóstias, seminaristas, doutores ou macarrão. Igualmente, é preciso controlar a qualidade e avaliar os resultados. Para isso, há inspetores de qualidade na fábrica e a Prova Brasil na educação.” (2008, p. 20)

Evidentemente que esse tipo de análise que nivela a fabricação de macarrão à formação de doutores, pode ser aplicado a aspectos bem restritos do processo educacional, ou seja, a certos conteúdos que possam ser avaliados por meio de exames unificados, como conhecimentos matemáticos e desempenho em leitura e interpretação de textos.

Entretanto, a aplicação de critérios empresariais como o controle de qualidade à educação deve ser vista com cuidado. O controle de qualidade empresarial necessita de uma redução na variabilidade de resultados para que a excelência dos produtos seja garantida, mas no processo de formação educacional importa, em grande medida, justamente o contrário, ou seja, a preservação da diversidade, singularidade e autonomia dos alunos, ou nas palavras de Nilson José Machado:

\footnotetext{
A qualidade da matéria prima, dos atores e dos processos envolvidos deve revelar-se em um produto final com variações mínimas nas características. Nenhuma empresa lograria qualquer certificado de qualidade se seus produtos, ainda que todos de bom nível, apresentassem um espectro divergente de características, mostrando-se renitentes a classificações e equivalências. Ocorre que, no entanto, que esta diversidade radical é, ou deveria ser, precisamente o caso paradigmático, quando o "produto" esperado é o cidadão ativo, formado pelo sistema educacional.

No universo dos seres humanos, a incomensurabilidade dos espectros de habilidades e competências, a impossibilidade de rotulações ou classificações definitivas, ou relativamente estáveis, a parcial imprevisibilidade associada à administração das emoções e dos sentimentos, às regulações dos humores, tornam a minimização de variações uma meta absolutamente indesejável, que não encontra apoio em qualquer dado de realidade". (MACHADO, 2001, p. 2021)
}

\subsection{A esfera pública privatizada no Brasil}

A noção de espaço público e de seu declínio na Era Moderna conforme a análise de Hannah Arendt, que na verdade é um diagnóstico que não se aplica a nenhuma nação específica mas à Civilização Ocidental como um todo, encontra uma especial convergência com as interpretações que a nossa historiografia costuma fazer do Brasil, em especial as dificuldades do país em lidar com uma esfera pública, impermeável às injunções do domínio privatístico e onde predomine o valor da igualdade, dilema expresso no 
“englobamento" da "rua" (âmbito público) pela "casa” (âmbito privado), na dicotomia popularizada por Roberto DaMatta. (1997)

O movimento de "domesticar" as relações impessoais que se dão na esfera pública trazendo-as para o âmbito do tratamento pessoal e familiar expressa-se, por exemplo, na noção de "homem cordial" segundo a seminal descrição de Sérgio Buarque de Hollanda (2009).

O fenômeno do "jeitinho" brasileiro (BARBOSA,1992) o uso de expressões como “sabe com quem você está falando?"(DAMATTA, 1997), a idéia de que a lei é para os inimigos e tantos outros achados sociológicos e antropológicos corroboram com a percepção de uma privatização do interesse público no Brasil.

Dessa forma, a questão da cidadania no Brasil é um problema em aberto, de difícil equacionamento, mesmo diante dos evidentes avanços do nosso país, desde a sua constituição como nação independente. Se a cidadania tem em si um registro do princípio da igualdade, as características de formação histórica do Brasil, nunca foram exatamente propícias para que se firmasse a igualdade como uma idéia reguladora da vida cotidiana do meio social brasileiro.

É por demais conhecida a análise que se faz da cidadania em nosso país, reiteradamente no sentido de sua baixa qualidade ou mesmo, e talvez principalmente, a denúncia da sua inexistência concreta. Tanto que é recorrente na fala comum, nos textos jornalísticos e também no discurso acadêmico uma focalização na idéia de que é preciso “ construir a cidadania" ou "resgatar a cidadania", dando a entender que se trata de uma realidade que não está presente no cotidiano dos brasileiros, que precisa ser conquistada, mesmo diante de todos os avanços institucionais, sua ampla expressão na Constituição de 1988 e grande circulação nos discursos.

A própria intitulação de algumas obras ou artigos que tratam do tema "cidadania" nos dá alguma medida de que estamos a lidar com uma realidade cuja existência é colocada em dúvida ou que ainda está inacabada, em processo de afirmação, como por exemplo: "A cidadania que não temos" (MANZINI-COVRE, 1986); "Brasileiro: cidadão?" (DAMATTA et alii, 1992); "Hipocrisia: o mito da cidadania no Brasil" (MAMEDE, 1997); “O cidadão de papel” (DIMENSTEIN, 2002) .

É extremamente comum diagnósticos que indicam que a previsão legal de direitos não se realiza na prática da vida nacional: 
“(...) no Brasil, apesar de consagrarem o direito dos cidadãos, as leis freqüentemente permanecem letra morta ou, quando muito, são privilégio de uma minoria que possui os recursos necessários para fazer valer os seus direitos nos tribunais. Como não existe democracia sem normas legitimamente respeitadas por todos e instituições que as garantam, continuamos a viver em uma sociedade em que, em última análise, impera o arbítrio dos poderosos e a cidadania ampla é mera ficção. (COSTA, 2006, p.21-22)

As referências ao processo de formação histórica do Brasil ${ }^{64}$ dão conta das marcas que se sente até hoje advindas de uma sociedade escravista e hierarquizada.

Predominam, nas análises sobre o perfil do meio social brasileiro, as características indicativas de uma sociedade hierárquica, patrimonialista, desigual, pouco afeita a exigências de natureza pública. Os inúmeros trabalhos clássicos em nossa historiografia que sinalizam nessa direção, aparentemente, não foram desmentidos.

Em geral, as pesquisas ${ }^{65}$ que procuram revelar traços da cidadania no Brasil, apresentam um perfil indicativo de ausência de cultura cívica, pouco entusiasmo pela participação em causas coletivas em geral, e responsabilidade política restrita ao voto obrigatório.

Em pesquisa de opinião para indicar as características que melhor descreveriam o brasileiro, cujos dados são analisados por José Murilo de Carvalho (1999), sobressaíram-se a imagem de sofredor, trabalhador, alegre e conformado. $\mathrm{O}$ sofrimento e a alegria não seriam indicações contraditórias, pois segundo o autor, a alegria viria para contrabalançar a condição de sofredor, de vítima das circunstâncias sociais adversas ou do governo.

\footnotetext{
${ }^{64}$ Veja-se, por exemplo, o uso da expressão "homem bom" no período colonial, que nos ajuda a entender, a dificuldade atual de lidarmos com a idéia de igualdade que emana da noção de cidadania: "[homem bom é uma ]expressão utilizada na América Portuguesa para traduzir uma atitude mental típica do Antigo Regime, que era incapaz de considerar os indivíduos como nascidos iguais e dotados dos mesmos direitos. Ao contrário, eram o sangue, a linhagem, a ocupação e os privilégios que estabeleciam as diferenças (...) Assim, homem bom era aquele que reunia as condições para pertencer a um certo estrato social, distinto o bastante para autorizá-lo a manifestar sua opinião e a exercer determinados cargos. Na América Portuguesa, associava-se em particular àqueles que podiam participar da governança municipal, elegendo e sendo eleitos para os cargos públicos que estavam reunidos nas câmaras, principal instância de representação local da monarquia. Uma provisão de 1705 , por exemplo, determinava que estavam excluídos desse processo eleitoral 'os mecânicos, operários, degredados, judeus' e outros que pertencessem à categoria de 'peões' (..) Mantidas, no essencial após 1822, a legislação e as mentalidades do Antigo Regime português, a concepção de homem bom converteu-se na "boa sociedade" do império - que trajava casaca e ostentava títulos de bacharel . Revela-se, assim, a dificuldade da formação social brasileira em lidar com a noção de cidadania, que pressupõe, desde a Revolução Francesa, a igualdade de nascimento como um direito do indivíduo"( VAINFAS, 2000, p.284-286)

${ }^{65}$ Ver, por exemplo, Cidadania, justiça e violência ( PANDOLFI, 1999) , A cabeça do brasileiro (ALMEIDA, 2007).
} 
O brasileiro seria um sofredor conformado e alegre. Descrição perfeita desta autopercepção é o nome do bloco carnavalesco do Recife : "Nóis sofre mas nóis goza”. (...) do ponto de vista político e cívico, é a própria definição do nãocidadão, do súdito que sofre, conformado e alegre, as decisões do soberano. $\mathrm{O}$ povo se vê como vítima, como paciente e não como agente da história" (CARVALHO, 1999, p. 36)

O mesmo autor utiliza o modelo de Marshall para um fecundo estudo (CARVALHO, 2001) em que analisa o processo de afirmação da cidadania no Brasil.

No trabalho de Carvalho, observa-se que, no Brasil, há uma preponderância muito maior dos direitos sociais no imaginário da população, direitos que foram os primeiros a serem incorporados ao conjunto dos chamados "direitos de cidadania", em uma inversão na ordem sugerida por Marshall ${ }^{66}$.

O fato de os direitos sociais no Brasil (sobremaneira trabalhistas) terem sido concedidos em um período de Executivo forte ( Era Vargas), em que os direitos civis e políticos estavam sufocados, é indicativo de um processo de conquista de direitos menos como resultado de lutas e reivindicações e mais como concessão do poder instituído.

Isso de certa forma constrói uma percepção da cidadania como algo a ser concedido por quem detém o poder, em uma relação hierárquica onde vigora o paternalismo impregnado de uma visão privada das relações de natureza pública o que coincide com as leituras clássicas sobre as características da sociedade brasileira.

A descrição do cidadão brasileiro, no discurso das ciências sociais, é geralmente a própria condição do desamparo. Ser cidadão, no descolorido igualitário do termo, é um itinerário de grandes dificuldades para a obtenção de atendimento médico, educação, transporte coletivo, habitação etc. Segundo Roberto DaMatta, “a palavra 'cidadão' é usada sempre em situações negativas no Brasil, para marcar a posição de alguém que está em desvantagem ou mesmo inferioridade". (1997, p. 80)

Para não se perder na burocracia que é reservada aos que são comuns, importante é revelar uma condição pessoal diferenciada ou ser conhecido de alguma figura proeminente, ou seja, dispor de alguma forma de poder que force uma atenção diferenciada contornando o tratamento comum. "No mundo social brasileiro, o que sempre se espera em qualquer situação de conflito é o ritual do reconhecimento, que humaniza e personaliza as situações formais, ajudando todos a hierarquizar as pessoas implicadas na situação".(DAMATTA, 1997, p. 80)

\footnotetext{
${ }^{66}$ Vimos o modelo de Marshall no capítulo 3.
} 
É curioso o uso difundido da expressão "cidadão comum". Se é verdade que é uma forma de expressão que pode designar, por exemplo, o cidadão não está no exercício de nenhum cargo público ou, de maneira mais geral no uso da língua, alguém que não é especializado em algum assunto não deixa de abrir espaço para se pensar que se há o “cidadão comum" é porque existiria o "cidadão incomum" ou "especial” o que é um paradoxo, já que um "cidadão especial” coloca que xeque a própria noção de cidadania, enquanto registro de igualdade

O tratamento não igualitário pelas próprias instituições públicas, geram desconfiança em relação ao Poder Público com o qual o cidadão não quer se identificar, nem tomar parte. O Poder Executivo e Legislativo são vinculados à corrupção e em relação ao Poder Judiciário, há uma crença generalizada de que o aparelho judicial tende a favorecer quem tem maior poder econômico ${ }^{67}$.

\footnotetext{
${ }^{67}$ No premiado estudo Robin Hood versus King John, o pesquisador Ivan César Ribeiro procurava verificar, por meio de estudo empírico, a imparcialidade do Poder Judiciário quando tem que decidir sobre divergências em cumprimento de contratos envolvendo duas partes em desnível de poder econômico e político. O autor testou duas hipóteses antagônicas: a de que os juízes teriam a tendência de julgar favoravelmente à parte economicamente mais fraca, como se fossem a encarnação de "Robin Hood" e a de que há uma subversão em decisões que envolvem litigantes em desnível de poder favorecendo-se a parte mais poderosa e influente, ou seja, uma justiça à "King John". Ora, o autor concluiu que há uma tendência dos juízes favorecerem a parte economicamente mais poderosa. Entre outras conclusões, o autor aponta que "uma parte com poder econômico ou político tem entre $34 \%$ e $41 \%$ mais chances de que um contrato que lhe é favorável seja mantido do que uma parte sem poder".
} 


\section{EDUCAÇÃO PARA A CIDADANIA PARTICIPATIVA}

O diagnóstico de Hannah Arendt sobre a Era Moderna caracterizada pela dissolução do espaço público e suas conseqüências deletérias para a ação política é um esforço de compreensão do fenômeno e não a proposta de um programa de superação do estado de coisas indicado, de forma que, como escreve André Duarte:

(...) o problema por ela detectado não é de ordem circunstancial, não podendo ser resolvido por meio do apelo cívico e bem intencionado à participação política. $\mathrm{O}$ moderno encolhimento da esfera pública e o obscurecimento da participação política não são circunstanciais, mas sim constitutivos da modernidade, de modo que não podem ser superados invocando-se uma mera mudança de mentalidade. (2002, p.66)

Diante da contundência do excerto que citamos acima e da já conhecida índole pouco cívica do povo brasileiro, que parece ser uma marca cultural de grande perenidade, fica-se com uma sensação de beco sem saída, pois fica comprometida a aposta na mudança das mentalidades e na contribuição que a educação pode ter nesse processo.

Entretanto, mesmo considerando as evidências de que a contemporaneidade se apresenta marcadamente hostil à política, há uma presença discursiva da temática do cidadão e o conseqüente enaltecimento quase unânime da educação voltada ao preparo para o exercício da cidadania.

Esse aparente paradoxo nos estimula a indagar, então, por que cidadania, ou por que educação para a cidadania em um mundo avesso à política? Essa urgência e profusão de discursos valorizando a cidadania nos leva a pensar em dois caminhos básicos para a reflexão sobre educação para a cidadania, que desfaz o paradoxo apresentado:

1. Afirmar, mesmo diante do declínio da esfera pública, a importância da cidadania enquanto participação política e dos valores cívicos a ela inerentes.

2. Fazer uso de uma noção de cidadania alargada de forma a receber tamanha gama de sentidos, que o teor político é diluído ou apenas representa uma parte irrelevante.

Assim, designa-se como "cidadão", o consumidor, o filantropo, o empreendedor, e outras categorias não-políticas. 
No presente capítulo, discutiremos a educação para a cidadania, levando em conta a idéia de uma formação voltada para a participação na esfera pública, mesmo diante do quadro adverso à política que foi apresentado no capítulo anterior.

\subsection{Formação do cidadão e educação do povo}

Há em jogo, pelo menos duas abordagens distintas mas interrelacionadas quando se discute educação para uma participação ativa na esfera pública.

A primeira leva em consideração que os destinatários da educação são os jovens,de forma que a educação para a cidadania é vista sob um prisma de formação daqueles que ainda são novos no mundo. A educação nesse caso, nas palavras de José Sérgio Fonseca de Carvalho, é "o ato de acolher e iniciar os jovens no mundo, tornando-os aptos a dominar, apreciar e transformar as tradições culturais que formam nossa herança simbólica comum e pública”. (2008, p.266)

Ora, sem uma familiarização com o mundo, não se aprende a apreciá-lo, e sem o apreço não há interesse em conservá-lo ou de responsabilizar-se pelo seu destino ou de deixar nele uma contribuição singular por meio da ação política.

Sob esse prisma, a educação está destinada ao preparo do jovem que ainda não é cidadão.

A segunda abordagem, considera a educação para a cidadania, não propriamente como uma iniciação de jovens, mas como um processo de aprendizado do povo. Essa abordagem é feita por Maria Victoria Benevides em grande parte de seus escritos e selecionamos um excerto em que há bastante clareza em suas intenções: "a educação política - entendida como educação para a cidadania ativa - é o ponto nevrálgico da participação popular. Mas esta educação se processa na prática. Aprende-se a votar, votando". (1994, p. 10)

Esse enfoque valoriza a participação efetiva daqueles que já são cidadãos, de forma que a educação, nesse caso, está voltada para o exercício reiterado e responsável da cidadania. Daí porque, a autora se preocupou, em demonstrar amplamente em seu estudo Cidadania Ativa (1991) a vantajosa complementaridade que os instrumentos de democracia direta (referendo, plebiscito e iniciativa popular) trazem para a democracia 
representativa e para o aperfeiçoamento da Democracia em sentido mais geral, como forma superior de viver a política.

Entretanto, essas abordagens são complementares na medida em que o jovem em formação se espelhará nos modelos existentes ao seu redor.

A esse propósito, Montesquieu, ao comparar a educação dos antigos e a educação vigente em seu tempo, escreve que a educação recebida pelos antigos nunca era desmentida e que "hoje, recebemos três educações diferentes ou contrárias: a de nossos pais, a de nossos professores, a do mundo. O que nos contam na última delas vira de cabeça para baixo todas as idéias das duas primeiras.” (2005, p.45)

\title{
5.2. Cidadania e Democracia
}

Aristóteles assim inicia o Livro VIII da Política :

\begin{abstract}
Ninguém contestará que a educação dos jovens requer uma atenção especial do legislador, pois a negligência das cidades a este respeito é nociva aos respectivos governos; a educação deve ser adequada a cada forma de governo, porquanto o caráter específico de cada constituição a resguarda e mesmo lhe dá bases firmes desde o princípio- por exemplo, o caráter democrático cria a democracia e o caráter oligárquico a oligarquia(...)
\end{abstract}

Portanto, a Educação segue a configuração política dada a um Estado.

O Estado brasileiro desejando se firmar como uma democracia, evidentemente, solicita uma educação que esteja afinada com os valores democráticos.

O cidadão, no dizer de Philippe Ardant, introduziu com ele a democracia; não há cidadãos sem democracia ou democracia sem cidadãos. (apud BARACHO, 1995, p.1))

Essa observação tem mérito de apresentar, em fórmula lapidar, a vinculação entre cidadania e democracia. Entretanto, é preciso reconhecer que, se de um lado não há democracia sem cidadãos, de outro é possível conceber cidadãos sem democracia.

Concordando com Maria Victoria Benevides, é importante destacar que:

(...) nos referimos sempre à cidadania democrática. Existem casos de regimes políticos que levaram ao extremo a educação para a cidadania, em termos de mobilização cívica, mas não em termos de cidadania democrática, Regimes totalitários levaram ao extremo a formação do cidadão ligado à pátria, à nação, ao seu passado histórico, ao projeto de futuro". ( BENEVIDES, 2000, p. 5) 
$\mathrm{Na}$ verdade, em um regime totalitário não podemos sequer falar em educação no seu sentido formativo. Hubert Hannoun em seu estudo sobre a educação nazista, conclui que "não há teoria nacional-socialista hitleriana da formação" (1997, p. 232), ou seja, não há propriamente formação, mas um adestramento destinado a produzir respostas bioafetivas rejeitando-se qualquer atividade mais reflexiva do indivíduo:

\begin{abstract}
(...) se a educação autêntica, global, é não só formação da bio-afectividade, mas também adesão crítica do educando às suas próprias transformações, a expressão "educação nazi" parece-nos contraditória. Os factos e os textos que se lhe referem revelam apenas o adestramento de uma individualidade reduzida à dimensão corporal e bio-afectiva. (1997, p. 230- 231)
\end{abstract}

Regimes de força interessam-se pela cidadania sempre visando uma homogeinização das individualidades sob um manto de pertencimento comum, como o sentimento de patriotismo. Assim, no Brasil, no período de ditadura militar, foi editada a lei $5692 / 71^{68}$, cujo teor do art. $1^{\circ}$ é o seguinte: “O ensino de $1^{\circ}$ e $2^{\circ}$ graus tem por objetivo geral proporcionar ao educando a formação necessária ao desenvolvimento de suas potencialidades como elemento de auto-realização, qualificação para o trabalho e preparo para o exercício consciente da cidadania". (grifo nosso)

O exercício da cidadania, portanto, como finalidade da educação, tanto pode ter guarida legal em um regime autoritário, como em um regime democrático.

E o que dizer do decreto-lei 869/69 que instituiu a obrigatoriedade do ensino de educação moral e cívica nas escolas de todos os graus no Brasil? Também essa iniciativa partiu das autoridades militares, em um regime desfavorável à liberdade política e à democracia.

\title{
5.3. Cidadania participativa e a noção de "direito a ter direitos"
}

É notável na bibliografia pesquisada, a utilização freqüente da expressão "direito a ter direitos" como um conceito de cidadania que é repetido quase como um slogan.

A difusão da frase é grande e há inclusive uma obra cujo título é simplesmente, $O$ direito a ter direitos(2000), sem nenhum subtítulo, tal é a crença de que o público leitor fará a conexão entre o título e a temática da cidadania.

\footnotetext{
${ }^{68}$ Essa lei trouxe alterações em nossa primeira Lei de Diretrizes e Bases da Educação (Lei 4024/61).
} 
A referência mais famosa a essa construção verbal encontra-se no primeiro livro de Hannah Arendt, As Origens do Totalitarismo, no capítulo intitulado "O declínio do Estadonação e o fim dos direitos do homem".

Ali, Arendt descreve de forma pungente a dramática situação dos refugiados e apátridas que destituídos da proteção de seus países de origem, em função das reconfigurações territoriais na Europa e da experiência do totalitarismo, circulavam pelo continente privados de sua cidadania, privados de direitos, e a calamidade maior: privados “de um lugar no mundo que torne a opinião significativa e a ação eficaz". (2007, p. 330).

“Andávamos, então, trocando de países como de sandálias”, diz o verso de BRECHT em seu famoso poema "Aos que vão nascer".

O período histórico examinado por Arendt colocou à dura prova os direitos humanos proclamados em declarações voltadas a um homem abstrato, para quem seriam desnecessários vínculos jurídico-políticos, mas tão somente o pertencimento à família humana universal. Sem pertencimento a uma comunidade política, a nudez do homem em sua crua natureza não foi o suficiente para lhe garantir proteção.

Diz Arendt que "não nascemos iguais; tornamo-nos iguais como membros de um grupo por força da nossa decisão de nos garantirmos direitos reciprocamente iguais". (2007, p.335)

A igualdade natural, aquela que não é um construído humano, é ditada pelos condicionamentos da necessidade. Os homens são iguais naturalmente porque necessitam de se alimentar, porque precisam de descanso, porque são sensíveis ao fogo, porque morrem.

Já havíamos nos referido no capítulo 3 à metáfora da máscara teatral (persona), indicando a artificialidade de construção humana de que se reveste a cidadania.

Shylock, o célebre personagem de Shakespeare, ao descrever em sua conhecida fala $^{69}$, as características que igualariam os judeus e os cristãos e justificariam inclusive a vingança, fala de uma igualdade baseada em características humanas sensíveis. Os seres humanos assim igualados por dados de natureza são a base de muitas justificativas da universalidade dos direitos humanos.

\footnotetext{
${ }^{69}$ Referimo-nos ao trecho de $O$ Mercador de Veneza : "Os judeus não têm olhos? Os judeus não têm mãos, órgãos, dimensões, sentidos, inclinações, paixões? Não ingerem os mesmos alimentos, não se ferem com as armas, não estão sujeitos às mesmas doenças, não se curam com os mesmos remédios, não se aquecem e refrescam com o mesmo verão e o mesmo inverno que aquecem e refrescam os cristãos? Se nos espetam, não sangramos? Se nos fazem cócegas, não rimos? Se nos derem veneno, não morremos? E se nos ofenderem, não devemos nos vingar? Se em tudo o mais somos iguais, teremos que ser iguais também a esse respeito".
} 
As experiências da primeira metade do século XX mostraram que o ser humano por si só, desprovido de seu vínculo jurídico-político concreto estaria desprotegido, por mais que as declarações de direitos humanos aclamassem o valor do ser humano abstrato e universal e a igualdade natural de todos.

Conforme Arendt:

Só conseguimos perceber a existência de um direito de ter direitos ( e isto significa viver numa estrutura onde se é julgado pelas ações e opiniões) e de um direito de pertencer a algum tipo de comunidade organizada, quando surgiram milhões de pessoas que haviam perdido esses direitos e não podiam recuperá-los devido à nova situação política global (2007, p. 330)

Daí porque, nas palavras de Celso Lafer, os direitos humanos "não são dados" (physei), mas "construídos" (nomoi) no âmbito de uma comunidade política. (2003, p. 123)

Dessa forma, a crítica de Arendt aos direitos humanos não se dirigem a eles como tais, "mas ao pressuposto segundo o qual tais direitos encontrariam seu fundamento na natureza do homem, implicando assim uma redução da política à natureza".( DUARTE, 2000, p.48)

Destaquemos que a expressão "direito a ter direitos" reserva para si um enfoque interpretativo diverso. A frase possui a interpretação de que os direitos são condicionados historicamente e que, no lugar de se dizer que temos direitos de conteúdos específicos como direito à propriedade, direito à saúde, direito a um meio ambiente equilibrado, melhor seria usar a fórmula aberta "direito a ter direitos" que vislumbra não só o que existe hoje como direitos, mas também a inclusão de novos direitos no futuro, sejam quais forem, de forma que não haveria uma determinação fechada de direitos a pertencerem ao acervo do homem.

É o que nos parece dizer Evelina Dagnino, quando enfoca a importância dos movimentos sociais de caráter reivindicatório para a noção de cidadania

(...) a nova cidadania trabalha com uma redefinição da idéia de direitos, cujo
ponto de partida é a concepção de um direito a ter direitos. Essa concepção não
se limita portanto a conquistas legais ou ao acesso a direitos previamente
definidos, ou à implementação efetiva de direitos abstratos e formais, e inclui
fortemente a invenção/criação de novos direitos, que emergem de lutas
específicas e da sua prática concreta. (2004,p.107-108)

Entretanto, a ênfase de Arendt não está a serviço de proclamar a inesgotabilidade dos direitos em sua linha histórica (pelo menos não explicitamente), mas sim enfatizar que 
a pertença a um corpo político (cidadania) é o direito elementar que permite criar e fazer valer qualquer outro direito.

Ou nas palavras de Mariângela Nascimento, "a questão de direitos não se resume na garantia legal das demandas sociais reivindicadas, mas no direito a ter acesso às condições de lutar por eles." (2008, p. 69)

O homem sem cidadania estaria fora do mundo. Portanto, direito a ter direitos estaria a sinalizar que o direito-matriz, sobre o qual os outros direitos são tributários é a participação em efetiva em uma comunidade política, por meio do instituto da cidadania.

\title{
5.4. Participação política e proteção jurídica
}

Como já apontamos em outros momentos desta dissertação, a cidadania apresenta duas conotações básicas: participação política, oriunda da experiência da polis grega e garantia de direitos ou status jurídico, cuja formulação moderna se deu na formação do Estado Liberal, incrementada pelos direitos sociais durante o século XX .

Conforme nos lembra Elisa Reis,

\begin{abstract}
Claro que estas duas dimensões podem convergir. Embora não haja necessariamente discordância lógica entre virtude cívica e usufruto de direitos, também é verdade que pode haver divergência lógica e empírica entre uma noção cívica e uma noção consumidora de direitos. O cidadão consumidor de direitos pode, por exemplo, usar sua liberdade para se isolar na esfera privada, para não exercer virtudes cívicas na esfera pública" $(1999$, p.14)
\end{abstract}

Hannah Arendt faz uma observação semelhante no tocante ao uso de direitos para promover o isolamento, na obra Homens em tempos sombrios

(...) o âmbito público perdeu o poder iluminador que originalmente fazia parte de sua natureza. Um número cada vez maior de pessoas nos países do mundo ocidental, o qual encarou desde o declínio do mundo antigo a liberdade em relação à política como uma das liberdades básicas, utiliza tal liberdade e se retira do mundo e de suas obrigações junto a ele. Essa retirada do mundo não prejudica necessariamente o indivíduo; ele pode inclusive cultivar grandes talentos ao ponto de genialidade e assim, através de um rodeio, ser novamente útil ao mundo. Mas, a cada uma dessas retiradas, ocorre uma perda quase demonstrável para o mundo; o que perde é o espaço intermediário específico e geralmente insubstituível que teria se formado entre esse indivíduo e seus companheiros homens". (ARENDT, 2008, p.11-12) 
A participação política, essência da cidadania antiga, é modernamente transfigurada pela representação parlamentar sendo-lhe atribuída a nomenclatura de "direitos políticos" na chamada "Era dos direitos".

Entretanto, a mentalidade de fruição de direitos parece mal aplicável aos direitos políticos, porque, ao contrário dos direitos civis e sociais, eles evocam mais claramente responsabilidades para com a esfera pública do que propriamente direitos a serem gozados na esfera particular.

Renato Janine Ribeiro lembra que os direitos privados são em grande medida facultativos, podendo ou não ser desfrutados, mas que em relação aos direitos políticos o mesmo não acontece, pois o indivíduo "pode decidir nunca desfrutar de seu direito de propriedade, mas é duvidoso que uma democracia possa subsistir se seus cidadãos se recusarem a tomar parte na constituição do poder político". (2008, p.24)

Retomando a clássica enunciação dos direitos fundamentais em gerações ou dimensões, como sabemos os direitos civis e políticos são mencionados, normalmente, como componentes da primeira geração de direitos e os direitos sociais como integrantes da segunda geração de direitos. Além dessas duas, teríamos uma terceira geração composta pelos direitos difusos, e há quem fale em quarta e quinta dimensões de direitos.

Mas nos mantendo nas duas primeiras gerações, a natureza diversa desses direitos foi materializada no tratamento em separado dado a eles nos dois pactos de direitos humanos firmados em 1966 para dar maior juridicidade aos direitos consagrados na Declaração Universal dos Direitos Humanos de 1948: de uma lado o Pacto Internacional sobre Direitos Civis e Políticos, de outro o Pacto Internacional sobre Direitos Econômicos, Sociais e Culturais ${ }^{70}$.

Sabemos que nos dias de hoje a fragmentação e separação estanque desses direitos não é admissível dada a intrínseca relação entre eles, certeza corroborada pela Declaração de Viena de 1993, documento em que os direitos civis e sociais são considerados oficialmente pela comunidade internacional como indivisíveis. A dignidade da pessoa humana é um todo para cuja preservação contra violações, contribuem todas as esferas de direitos concatenadas.

\footnotetext{
${ }^{70}$ A separação dos direitos em dois tratados se deu por razões ideológicas, fruto do período de Guerra Fria. Foi uma solução contemporizadora já que a aceitação unânime de um Pacto que previsse tantos direitos civis e políticos como os sociais por tornou-se impossível em função das restrições da URSS em relação aos direitos civis e políticos, e das restrições dos Estados Unidos em relação aos direitos sociais. Com a divisão dos direitos em dois documentos distintos, pelo menos, evitava-se a rejeição total da lista de direitos humanos por esses países.
} 
De qualquer forma, essa classificação em gerações (primeiro o surgimento dos direitos civis e políticos; depois os direitos sociais) além de importante para efeito didático-descritivo, é muito difundida. Ela leva em conta um itinerário cronológico no aparecimento dos direitos, conforme indicamos no capítulo 3.

Isso não a impede de receber críticas e é evidente que a divisão dos direitos fundamentais, embora seja classicamente feita nesse sistema de gerações ou dimensões, pode ser realizada por outras formas, levando em conta outros critérios. ${ }^{71}$

Para os nossos fins, considerando que não nos interessa tão somente a classificação dos direitos fundamentais, mas também a correlação desses direitos com um enfoque de cidadania apropriado para as preocupações da educação em conformidade com a Constituição de 1988, talvez fosse oportuno fazer um pequeno exercício classificatório levando em conta justamente as duas conotações básicas, ou seja, cidadania enquanto participação política e enquanto proteção jurídica.

Cremos que o destaque a esses enfoques, permite esclarecer melhor parte da confusão gerada pelos discursos sobre cidadania, pois, muitas vezes, o que se pretende discutir sob o título geral de cidadania ora se traduz em uma ênfase no aspecto "proteção jurídica", ora a ênfase recaí sobre o aspecto "participação política". Faz muita diferença saber sobre qual dessas duas perspectivas se está falando, principalmente para os fins da educação conforme a Constituição Federal. Antes de exemplificarmos melhor o que estamos propondo, voltemos ao problema classificatório, utilizando esses dois enfoques.

Como já mencionamos, usualmente os direitos civis e políticos são tratados em bloco, como a primeira geração de direitos, em função de sua relação de proximidade. Depois, há a enunciação dos direitos sociais.

\footnotetext{
${ }^{71}$ Brito Filho (2008) faz duas criticas à essa classificação. Em primeiro lugar diz que é uma classificação histórica e que, portanto, não se utiliza de critérios jurídicos. Além disso, é uma classificação que não goza de estabilidade já que o número de categorias de direitos humanos vão aumentado ao sabor da evolução social e das novas necessidades de proteção da dignidade da pessoa humana. Além disso, como é natural supor, se novos direitos de natureza civil ou social surgirem e forem classificados em uma nova geração, desestruturam a base teórica que orientou a divisão originalmente. (Brito Filho, 2008)

$\mathrm{O}$ autor sugere, sem abdicar da classificação dos direitos em dimensões, uma classificação cujo referencial não é "o momento do surgimento dos direitos, e, sim, o próprio interesse protegido, do ponto de vista do titular".(BRITO FILHO, 2008, p 41)

Segundo o autor , "assim, mantendo a classificação dos direitos humanos em três dimensões, mas vinculando-a ao interesse protegido, é possível dizer que, a primeira dimensão, dos direitos civis e políticos, relaciona-se aos direitos individuais; a segunda dimensão, dos direitos econômicos, sociais e culturais, relaciona-se aos interesses das coletividades e dos grupos, aos direitos coletivos em sentido estrito, portanto, usando a divisão dos interesses coletivos proposta pelo artigo 81. Parágrafo único, da Lei n. 8.078/90, o Código de Defesa do Consumidor; e a terceira geração refere-se aos interesses difusos (ex. meio ambiente como patrimônio comum da humanidade) (...) (Brito Filho, 2008, p.42)
} 
Entretanto, para efeito do que estamos sugerindo, poderíamos considerar um desmembramento dos direitos civis e políticos, não em função do critério cronológico como no modelo de Marshall em que há uma separação temporal entre o surgimento dos direitos civis (século XVIII) e direitos políticos (século XIX), mas porque os direitos políticos estariam vinculados à noção de cidadania enquanto participação ao passo que os direitos civis estariam vinculados à noção de cidadania enquanto proteção jurídica. Juntarse-iam aos direitos civis, pelo mesmo critério, os direitos sociais e difusos.

Teríamos assim o aspecto participativo da cidadania, albergando, em uma linguagem de direitos, os direitos políticos e o aspecto protetor congregando os direitos civis, sociais e difusos. ${ }^{72}$

Com essa distinção entre os aspectos protetor e participativo é possível visualizar o que está em jogo nas bandeiras reivindicatórias envolvendo a noção de cidadania e direitos como, por exemplo, a questão da dicotomia inclusão e exclusão social.

É francamente difundida a utilização da noção de cidadania nas falas sociais que denunciam a "exclusão social". Mas note-se que nem sempre fica claro que é diferente tratar do tema da inclusão/exclusão caso consideremos a cidadania enquanto proteção ou enquanto participação.

Sob o enfoque da proteção, é inadmissível a exclusão dos brasileiros no tocante aos benefícios da riqueza nacional, aos direitos sociais em geral e às garantias civis. Todos devem estar inclusos. São bem conhecidas as mazelas relativas à efetivação dos direitos civis e sociais, e o Brasil costuma figurar em relatórios de organismos internacionais com destaque no quesito violação de direitos humanos.

Ocorre que cidadania, na perspectiva de participação política, possui algumas particularidades que alteram as premissas do discurso da exclusão/inclusão.

A luta contra a exclusão e a afirmação da necessidade do esforço pela inclusão social como tarefa a ser cumprida pela cidadania, ou seja, a demarcação clara e antitética entre exclusão e inclusão, traz um paradoxo, porque a cidadania em sua dimensão de participação política sempre teve (e mantém) um aspecto de exclusão ${ }^{73}$.

Cidadão na polis grega, ou seja, aquele que está apto a participar dos negócios públicos, é o indivíduo que não é escravo, não é mulher, e não é estrangeiro. A afirmação

\footnotetext{
${ }^{72}$ Seria uma forma de retomar, guardadas as proporções, as dicotomias de Kymlicka e Wayne Norman e de George Armstrong Kelly que apresentamos no item

${ }^{73}$ Excetuando-se talvez, uma acepção amplíssima de "cidadão do mundo".
} 
de quem é cidadão se dá pela exclusão. No Brasil Império, a condição de cidadão ativo, no sentido de ser detentor de direitos políticos era restrita aos homens, não escravos, detentores de certa renda. A afirmação da cidadania é excludente.

A cidadania no Brasil contemporâneo (reiteramos: no sentido de participação política) é, pelo menos no plano jurídico-formal, abrangente, mais inclusiva do que jamais foi em sua história, democrática não fazendo distinção de gênero, raça, condição econômica, nível de instrução.

Nas palavras de Ralf Dahrendorf, "as sociedades modernas têm um conceito mais generoso de quem pertence e quem não pertence a elas do que o de Aristóteles". (1992, p.42)

No entanto, a exclusão persiste e continua tendo o papel de afirmar quem é cidadão. Assim é, por exemplo, em relação àqueles que são estrangeiros e em relação às crianças. Embora em relação ao estrangeiro situações geradas pela globalização (por exemplo, circulação de trabalhadores fixando-se durante algum tempo em países diferentes ) possam apresentar uma realidade que se encaminhe para a concessão de certos direitos inerentes à cidadania enquanto participação política, no tocante às crianças parece-nos exagerado falar em termos de cidadania infantil. Nesse ponto, há um limite para a capacidade inclusiva que se deseja para a cidadania, e é claro, essa questão nos interessa de perto já que para a criança cabe o preparo para a cidadania por meio da educação.

Embora uma criança recém-nascida, para ficarmos com uma situação extrema, seja titular de direitos fundamentais, inclusive como sujeito de cuidados não apenas da família, mas da sociedade como um todo, ela ainda não pode exercer a cidadania no sentido de participar da vida pública, não dispondo sequer de linguagem desenvolvida como forma de expressão de vontade. Sua condição de cidadã, será tão somente no sentido de proteção jurídica.

A cidadania enquanto participação política, só será adquirida pela criança, justamente quando deixar para trás a condição de criança. A participação política exige, no vocabulário de Hannah Arendt, que se assuma a responsabilidade pelo mundo.

O término do tempo regular da educação escolar coincidirá com a idade em que, por convenção jurídica, marcamos a habilitação dos mais jovens a tomarem parte da vida pública. Os estudantes do último ano do ensino médio estão próximos ou já inclusos na categoria de brasileiros aptos a participar na condução dos destinos políticos do país e/ou aptos a participarem mais plenamente da vida civil de maneira geral. 
Afinal aos 16 anos o jovem tem direito ao voto facultativo; aos 18 anos o jovem vota obrigatoriamente; 18 anos é a idade mínima para um cidadão candidatar-se ao cargo de vereador; 18 anos é a idade para o serviço militar obrigatório; 18 anos é a idade da maioridade civil e da maioridade penal; 18 anos é a idade mínima para a inscrição em concursos públicos; 18 anos é a idade mínima para habilitação de motorista, etc.

Estamos cientes do caráter ideal da nossa descrição, pois a realidade que atinge expressiva parte da infância brasileira inclui abandono, precocidade em lidar com os expedientes que garantam o sustento, um mergulho sem estágios na luta pela sobrevivência.

Assim, pelo menos em tese, o tempo de vivência escolar coincide com o "preparo para a cidadania", que só pode ser "preparo", pois o exercício da cidadania propriamente, só pode se dar fora da escola, quando o indivíduo, já livre de ser objeto do dever de proteção de todos os adultos, assume junto aos outros a sua cota de responsabilidade pelo destino comum.Isso não significa, obviamente, que apenas aqueles que passam pela instituição escolar é que podem ser chamados de "cidadãos". Mas as crianças, na escola ou fora dela, só serão cidadãos no sentido de participação política quando não forem mais crianças.

Por isso, a concepção de uma "criança-cidadã" só pode ser compreendida no sentido de se pensar a cidadania como proteção jurídica.

Nesse sentido, leia-se o seguinte trecho de autoria de Miguel Arroyo:

\begin{abstract}
Quando falamos em 'educação para a cidadania', 'escola para a cidadania', formaremos crianças para a cidadania, formaremos adolescentes para a cidadania, significa que não aceitamos que eles já são cidadãos. Prefiro dizer que a criança já é cidadão, que a criança que está sendo gestada já é cidadão e merece um pré-parto digno de um cidadão, merece ser amada e respeitada porque o filho e a própria mãe já são cidadãos . Criança, quando chega na escola, não é um cidadão em potencial que vamos formar, é um cidadão de fato que temos que respeitar. Prefiro dizer escolas dignas de uma infância cidadã do que escolas com conteúdos que preparem para que um dia sejam adultos cidadãos como se apenas o adulto fosse cidadão". (2002, p.40)
\end{abstract}

O autor diz que a criança, ao entrar na escola, já é cidadã e, sob esse ponto de vista não se diferenciaria do adulto. Note-se como está implícito no trecho destacado, a noção de cidadania como proteção jurídica ou garantia de direitos fundamentais. Entretanto, se olharmos a questão sob ponto de vista de participação política, poderíamos afirmar que só os adultos são cidadãos, tendo ou não passado pela escolarização formal. 
Também é no sentido de proteção jurídica que podemos entender a intenção de obras como Cidadania antes dos 7 anos, cujo objetivo é avaliar como a educação infantil é tratada nos meios de comunicação. Evidentemente, trata-se de divulgar e defender o direito da criança à educação infantil e não apregoar formas de participação política de crianças com menos de sete anos.

Trazendo de volta os conceitos de Hannah Arendt que apresentamos no capítulo 4, a visão de cidadania enquanto proteção jurídica a coloca a serviço da manutenção da vida, ou do labor, já que se trata da preservação de um mínimo existencial. O que dizer dos direitos civis tais como a vida e a propriedade e de direitos sociais como o trabalho e a saúde? Não podemos esquecer de que a "alimentação" passou a ser direito social reconhecido na Constituição de 1988, por meio da emenda constitucional n ${ }^{\circ} 64$ de 04/02/2010, e a sua natureza é claramente de manutenção da vida.

Ricardo Lobo Torres esclarece o conceito jurídico de mínimo existencial, que dá conta das garantias mínimas à dignidade humana:

\begin{abstract}
Os mínimos sociais, expressão escolhida pela Lei $\mathrm{n}^{\circ} 8742 / 93^{74}$, ou mínimo social ( social minimum) da preferência de John Rawls, entre outros, ou mínimo existencial, de larga tradição no direito brasileiro e alemão, ou direitos constitucionais mínimos, como dizem a doutrina e a jurisprudência americanas, integram também o conceito de cidadania.

Há um direito às condições mínimas de existência humana digna que não pode ser objeto de intervenção do Estado e que ainda exige prestações estatais positivas.

O mínimo existencial não tem dicção constitucional própria, Deve-se procurá-lo na idéia de liberdade, nos princípios constitucionais da igualdade, do devido processo legal, da livre iniciativa e da dignidade do homem, na Declaração dos Direitos Humanos e nas imunidades e privilégios do cidadão.

Despe-se o mínimo existencial de conteúdo específico. Abrange qualquer direito, ainda que originalmente não fundamental ( direito à saúde, à alimentação, etc.), considerado em sua dimensão essencial e inalienável (...)

Sem o mínimo necessário à existência cessa a possibilidade de sobrevivência do homem e desaparecem as condições iniciais da liberdade. A dignidade humana e as condições materiais de existência não podem retroceder aquém de um mínimo, do qual nem os prisioneiros, os doentes mentais e os indigentes podem ser privados( 1999 , p. 262-263)
\end{abstract}

Miguel Arroyo, comparando o momento atual com a luta dos profissionais da educação por participação política na época da abertura democrática, a partir da década de 1980, diz que:

Hoje a luta não se situa apenas e fundamentalmente no campo da participação política, mas dos direitos sociais mais elementares: viver, comer, dormir, casa,

\footnotetext{
${ }^{74}$ Trata-se da Lei Orgânica da Assistência Social.
} 
moradia, trabalho, emprego(...) o emprego condiciona ter ou não ter um filho, ter ou não ter um companheiro, companheira, ter ou não ter casa onde morar, adiar projetos humanos, adiar projetos de maternidade, paternidade, adiar uma operação, adiar a vida, adiar a dignidade humana. Isso hoje é cidadania. E muito mais do que reivindicávamos há vinte anos , "Diretas já". Hoje é "Comida , já”, "Marmita, já”, “Emprego , já”. (ARROYO, 2001, p. 41)

Aos olhos do autor, as carências de natureza social e a necessidade da garantia de um mínimo existencial assumem a absoluta centralidade na noção de cidadania. Não se trata de negar a premência da importância - inclusive política - do atendimento às necessidades básicas, mas tão somente de não as tomar como a questão fulcral da cidadania já que se o fizéssemos, a saciedade das necessidades básicas de sobrevivência representariam a plenitude da cidadania. O paradoxo estaria na constatação de que a liberdade política se restringiria à saciedade da necessidade, o que ninguém discordará, embora seja verdade que regimes autoritários podem se encarregar de fornecer essa garantia de subsistência mínima aos cidadãos tolhendo a participação política livre, o que também absolutamente indesejável.

Sabemos que a experiência de liberdade política, conforme os gregos nos legaram, pressupõe a superação das necessidades vitais de subsistência e é claro que ninguém poderá sequer pensar em participação política se estiver com fome ou sofrendo devido a necessidades básicas de qualquer natureza.

Entretanto, é preciso mencionar que a política, evocando mais uma vez Hannah Arendt, diz respeito ao que poderíamos chamar de "máximo existencial humano" em contraposição ao mínimo existencial necessário à sobrevivência, pois se trata da realização daquilo que mais claramente identifica o que é humano em um ser humano, diferenciandoo dos demais animais. É a atividade política, a ação, que dá ao cidadão os seus contornos verdadeiramente humanos.

\subsubsection{O direito à educação como um direito político}

O direito à educação é elencado como um direito social de segunda dimensão, na tradicional classificação dos direitos humanos.

Como discutimos acima, os direitos sociais estariam vinculados, de maneira geral, mais fortemente à manutenção da vida, ou ao labor, na conceituação de Hannah Arendt. 
Entretanto, parece que o direito à educação possui uma característica política que o diferencia dos outros direitos sociais previstos no art. $6^{\circ}$ da Constituição de 1988 , ou seja, a saúde, a alimentação, o trabalho, a moradia, o lazer, a segurança, a previdência social, a proteção à maternidade e à infância, a assistência aos desamparados.

O direito à educação é um direito cujo conteúdo é precondição para a política, e assim como os chamados "direitos políticos", possui uma faceta de dever especialmente pronunciada.

Conforme lembra BENDIX

(...) o direito a uma educação básica não se distingue do dever de freqüentar a escola. Em todas as sociedades ocidentais, a educação básica tornou-se um dever de cidadania,(....) Dois atributos da educação básica transformaram-na num elemento da cidadania: o governo tem autoridade sobre ela, e os pais de todas as crianças de um certo grupo etário (...) são obrigados por lei a providenciar para que os filhos freqüentem a escola" (BENDIX, 1996,p. 122)

$\mathrm{O}$ autor notou uma grande semelhança entre o direito à educação e os direitos políticos (no caso o voto):

Há uma semelhança familiar entre o direito de todos os cidadãos de participar (através do direito do voto) nos processos decisórios do governo e o dever de todos os pais de providenciarem para que seus filhos na faixa etária estabelecida freqüentem a escola (...) o direito de voto é facultativo, enquanto os benefícios da freqüência à escola são obrigatórios." (BENDIX, 1996, p. 122-123)

No caso do Brasil, a semelhança é ainda maior dado que a escolarização é obrigatória dos 4 aos 17 anos e o voto é obrigatório.

A esse respeito é comum se ouvir a observação de que se fôssemos mesmo uma democracia de verdade, o voto não seria obrigatório. Ora, a verdade é que os direitos políticos também são deveres e se não forem exercidos colocam em risco a própria continuidade da democracia. É claro que votar, simplesmente, não significa que se vive em uma democracia. Apenas estamos recorrendo ao símbolo mais evidente de soberania popular em uma democracia para deixar claro que a democracia exige participação popular, exige cidadania participativa. 


\subsection{Os discursos da negação, do resgate, da consciência e da construção}

Gostaríamos de comentar, ainda que brevemente, algumas formas de veicular o uso da noção de cidadania em discursos acadêmicos (ou não) quando se pretende discutir o tema da cidadania no Brasil, e que se apresentam como verdadeiros jargões sobre o assunto, com repercussões sobre as nossas perspectivas sobre o papel da educação.

Estamos nos referindo, mais especificamente a algumas expressões verbais recorrentes tais como "cidadania negada", "resgate da cidadania", "conscientização da cidadania" e "construção da cidadania". Vejamos cada uma dessas formulações.

A expressão "cidadania negada" é comumente encontrável para intitular estudos que envolvam cidadania em um viés problematizador, crítico sobre a forma de sua concretização no Brasil $^{75}$. Entretanto, essa forma de expressão pode dar a impressão, de que a cidadania é um atributo conferido de cima para baixo, dentro da hierarquia social, focando-se no papel inexpressivo do próprio cidadão, só lhe restando submeter-se a essa espécie de concessão burocrática da elite política dominante, que pode "negar" ou "conceder" a cidadania.

A cidadania que pode ser "concedida" ou "negada" é menos ambígua, a nosso ver, em uma acepção em que se está tomando o termo cidadania como nacionalidade ${ }^{76}$, de forma indistinta. Por exemplo: o sujeito pleiteia a cidadania italiana mas por insuficiência ou deficiência dos documentos apresentados, o processo de reconhecimento não resulta positivo, de forma que a cidadania é "negada".

Entretanto, não é esse o uso comum que se faz da expressão. Normalmente, “cidadania negada" pretende mesmo indicar a condição de penúria da afirmação da cidadania no Brasil, a falta de condições mínimas de segurança, higiene, etc., sua pouca efetividade, com fartos exemplos retirados do cotidiano.

Sendo assim, é um discurso que está ligado à cidadania em sua conotação de proteção jurídica, ou melhor, da falta dela.

Cidadania também tem uma articulação enunciativa com a idéia de "resgate". Nesse viés de compreensão, temos uma noção que procura contornar a condição de "negação" da cidadania. Está implícito no vocábulo "resgate", a idéia de trazer de volta, e

\footnotetext{
${ }^{75}$ Ver a obra organizada por Maria Helena de Souza Patto (2009), “Cidadania Negada: políticas públicas e formas de viver”. A obra traz um panorama da situação de concretização da cidadania no Brasil a partir de depoimentos colhidos em entrevistas nas quais figuram como entrevistados os cidadãos brasileiros vitimizados pela miséria, desemprego e inoperância do Poder Público.

${ }^{76}$ Ver diferença entre nacionalidade e cidadania no item
} 
quando se refere à cidadania, serve para descrever ou nomear providências de entidades ligadas ao poder público formal ou de organizações não governamentais no sentido de promover melhorias nas condições de carência de comunidades desassistidas.

O resgate normalmente implica programas, projetos visando a efetivação da cidadania. Referir-se à cidadania dessa maneira, pode revelar uma forma paternalista de encarar o problema e apresentar-se como uma concessão de cima para baixo, pois a sintaxe subjacente a toda essa concepção é que alguém devolve algo que foi perdido ou que nunca existiu $^{77}$ àqueles que não são cidadãos e só serão cidadãos pelas mãos daqueles que promovem o dito "resgate".

A cidadania enquanto resgate também está vinculada a idéia de proteção jurídica, ou seja, mais enquanto fonte de direitos do que no seu aspecto de participação.

Mas "cidadania" também transita nos discursos juntamente com a noção de "consciência". Cidadania seria a "consciência" dos nossos direitos e deveres. O termo "consciência" ou o adjetivo "consciente" apresentam-se como lugares-comuns recorrentes: "consciência ecológica", "consumidor consciente", "eleitor consciente" "paternidade consciente", etc.

Essa espécie de discurso, levado em sua literalidade, poderia lembrar um discurso psicanalítico, como se cidadania fosse algo que está no inconsciente do indivíduo e que precisa aflorar ao nível da consciência ou que se trata de qualidades ou disposições psicológicas de um indivíduo.

De fato o que está em jogo na conscientização, seria a tomada de conhecimento de algo até então desconhecido ou nebuloso, mas aquilo que precisa ser conhecido não está adormecido no próprio indivíduo, é externo a ele e precisa ser introjetado. O discurso da "conscientização" é muito comum quando se pretende discutir a educação para a cidadania, afinal implicaria, primordialmente, que o aluno conheça os seus direitos e deveres, ou melhor, deles se "conscientize".

Aparentemente, a consciência da cidadania já garantiria automaticamente o seu exercício. Refletindo sobre a noção de que a cidadania é a consciência de direitos, diz Ruth Cardoso:

Eu fico um pouco assustada porque agora todo dia na televisão nos deparamos com a frase: "a cidadania é a consciência de seus direitos". Há muitos anos, os

77 'Ênio Resende diz que " temos visto pessoas falarem ou escreverem algo parecido com 'necessidade de se resgatar a cidadania no Brasil'. Queremos crer tratar-se de uma idéia incorreta, visto que não se pode resgatar aquilo que nunca existiu." (1992, p.67) 
operários têm consciência de algo chamado 'mais-valia', e nem por isso a gente consegue mudar o capitalismo. (2004, p. 90)

Por fim, cidadania é descrita, comumente, como algo que se "constrói". A idéia metafórica da "construção" da cidadania é a que apresenta a maior representatividade na composição de títulos de obras publicadas sobre o tema ${ }^{78}$. A expressão parte da evidência de que se está a falar de um processo que exige tempo, empenho e participação de toda a coletividade dando a entender que não se trata de uma categoria pronta e nem de uma concessão ofertada ao bel-prazer do Estado ou por aqueles que detém o poder.

Aqui temos, portanto, uma idéia de processo de constituição onde o protagonismo do próprio do cidadão aparece com mais destaque.

Parece-nos que o discurso da cidadania negada, do resgate da cidadania e da consciência da cidadania, podem permitir percepções paternalistas, concessivas, com pouca ênfase no protagonismo do cidadão, embora não seja, muitas vezes, essa a intenção de quem se utiliza das expressões. O discurso da "construção" parece-nos o menos propenso a criar esse mal entendido, o que talvez até justifique a sua larga utilização.

De qualquer forma, a visão constitucional de cidadania, pelo menos em seu compromisso com a educação conforme o art. 205, não faz uso das noções de construção, resgate ou conscientização (embora tudo isso possa ser subentendido), mas de exercício.

A cidadania seria algo que se "exerce", implicando uma prática, uma realização de atos concretos que se traduzem em inserção na vida política nacional não só nos rituais periódicos das eleições, mas em todas as formas possíveis de participação proporcionadas por uma democracia.

Evidente que o "exercício" pressupõe alguma medida de "conscientização" e o próprio exercício promove um "resgate" em determinadas situações e contribui de forma geral, para a "construção" da cidadania em nosso país, de tal sorte que todas essas idéias afins.

\footnotetext{
${ }^{78}$ Exemplos: "A Construção da cidadania" (TEIXEIRA, 1986); ); "Escola: espaço de construção da cidadania"(BORGES...[et al.], 1994; “ A cidadania em construção: uma reflexão transdisciplinar" SPINK (Org.), 1994); "Construção da cidadania por meio do discurso escolar" (DELGADO,1995); "Construindo a Cidadania" (MOURA, MARINHO, MOREIRA, 1995); "LDB, Ensino Superior e Construção da Cidadania" (NASCIMENTO, GREGORIN FILHO, 2000); "A Construção dos Saberes e da Cidadania: da escola à cidade" (APAP...[Et al.], 2002); "Constituição e Construção da Cidadania"( DINALLI, FERREIRA, TEOTÔNIO,2005); "A construção da Cidadania: reflexões histórico-políticas" (CORRÊA, 2006); "O Supremo Tribunal Federal e a Construção da Cidadania" ( COSTA, 2006).
} 


\subsection{Algumas considerações sobre o "preparo" e sobre o "exercício" da cidadania}

Quando falamos em educação como "preparo para o exercício da cidadania”, em nível escolar, estamos imaginando que há uma formação preparatória cronologicamente anterior ao "exercício" propriamente dito da cidadania. O exercício pressupõe que o agente seja cidadão.

Já comentamos anteriormente essa questão. O cidadão exercitando-se nos mecanismos democráticos também está sendo educado, entretanto em um sentido mais amplo já que atingiu a maturidade convencional para os assuntos públicos.

O preparo, portanto, é atividade dentro da escola; o exercício é atividade fora da escola. A palavra grega skhole (cujo correspondente latino é otium- ócio) de onde se originou o vocábulo "escola" em português, significa basicamente isenção de atividade política.

No tocante ao preparo, que expectativa é mobilizada quando se fala em preparo para o exercício da cidadania? Espera-se uma preparação prática com base em manuais que privilegiem um passo a passo reivindicatório junto aos poderes públicos? É um conteúdo específico, um programa a ser abrigado em uma disciplina cujo nome contenha a palavra "cidadania" ? É uma forma de conduzir as práticas pedagógicas de todas as disciplinas que compõe o currículo do aluno? É uma educação resultante de uma certa maneira de conduzir todos os processos na escola, não só dentro de sala de aula?

O preparo para a cidadania seria elucidação dos mecanismos de participação populares, via instituições formais (Câmaras Municipais, Assembléias Legislativas e Congresso Nacional)? Seria a enumeração de formas de participação para além das instituições formais, incluindo os movimentos populares?

Educação para a cidadania envolveria simulações de situações práticas retiradas do universo político fora dos muros escolares tais como a formação de um mini-parlamento, utilização de expedientes típicos da democracia (uso do voto) para que os alunos decidam questões pedagógicas dentro da sala de aula?

Seria o incentivo à participação dos alunos nos processos decisórios de conselhos deliberativos escolares?

A democratização do acesso a vagas no sistema de ensino já é formar para a cidadania, implicitamente? O simples ministrar de um conteúdo de uma disciplina curricular qualquer , já é formação cidadã? 
Esses são apenas alguns exemplos de questões possíveis que podem ser discutidas quando o assunto é preparo para a cidadania no âmbito escolar.

Sem entrar no mérito de todas elas, passaremos a fazer algumas breves considerações sobre um dos aspectos mais recorrentes quando se fala em preparo para a cidadania.

Parece que há certa dominância em se destacar a necessidade de recorrer-se a um aprendizado de conteúdos específicos, na esperança de que esse conhecimento possa proporcionar a conduta que se espera do cidadão. Normalmente os conteúdos que devem ser aprendidos são de natureza jurídica, direitos humanos, aspectos de Direito Constitucional, entre outros. Há diversas propostas legislativas nesse sentido e apresentamos duas para exemplificar a questão que estamos expondo.

Tramita na Assembléia Legislativa do Estado de São Paulo o projeto de lei 619/2007 que tem o objetivo de incluir no programa do ensino fundamental e médio da rede pública noções de Direito e Cidadania:

\footnotetext{
Artigo $1^{\circ}$ - O conteúdo programático das séries do ensino fundamental e médio das escolas públicas do Estado incluirá noções de Direito e cidadania, com o objetivo de proporcionar aos educandos:

I - acesso a conteúdo básico da legislação brasileira em geral;

II - esclarecimento e conscientização sobre seus direitos e deveres, e sobre a importância do exercício da cidadania, individual e coletivamente.

Artigo $2^{\circ}$ - Ministrar-se-ão as noções de Direito e cidadania:

I - integrando-as à grade curricular correspondente às diferentes séries, atentando-se ao nível de compreensão das faixas etárias respectivas;

II - observando-se as normas e recomendações do Conselho Estadual de Educação;

III - realizando-se, sempre que possível, atividades de natureza extracurricular, incluindo visitas a órgãos públicos;

IV - dando-se enfoque interdisciplinar, sempre que possível, aos temas abordados;

$\mathrm{V}$ - mediante o permanente estímulo à efetiva participação dos educandos.

Artigo $3^{\circ}$ - Ulterior regulamentação estabelecerá as diretrizes programáticas básicas, e definirá competências e atribuições, no âmbito da Secretaria da Educação, concernentes à implantação do disposto nesta lei.

Artigo $4^{\circ}$ - As despesas decorrentes da execução desta lei correrão à conta das dotações orçamentárias próprias.

Artigo $5^{\circ}$ - Esta lei entra em vigor na data de sua publicação.
}

A justificativa do projeto contém as seguintes considerações:

(...)Na forma como a prevê a propositura, referida inclusão teria por objetivos proporcionar aos educandos acesso a conteúdo básico da legislação brasileira em geral, esclarecendo-os e conscientizando-os sobre seus direitos e deveres, e sobre a importância do exercício da cidadania, individual e coletivamente. 
O contato com crianças e adolescentes, de todas as faixas etárias, tem-nos permitido constatar, muito freqüentemente, a desinformação de expressiva parcela desses brasileiros sobre aspectos básicos e essenciais da organização político-jurídica de nosso País.

É preciso dar-lhes, então, elementos para compreender seus direitos e deveres, e, conscientes destes e daqueles, avaliar como seus atos e omissões têm potencial de repercutir na realidade, transformando-a.

Se a escola não lograr cumprir este que é um de seus papéis fundamentais, terá falhado na missão de dotar os educandos das condições e dos conhecimentos indispensáveis ao pleno exercício da cidadania. (...)

O outro projeto de lei, de número 374/2007, também da Assembléia Legislativa de São Paulo, dispõe sobre a obrigatoriedade no ensino médio da rede pública estadual, a matéria de "Introdução ao Estudo do Direito". Um dos trechos da justificativa nos esclarece sobre as intenções do legislador:

O jovem não pode ficar fadado ao desconhecimento de noções de cidadania, o que o imobiliza socialmente levando-o ao fracasso pessoal. As noções de cidadania, se não advindas do convívio familiar ou social, somente virão através do aprendizado do uso e aplicação do Direito em suas diversas formas.

A questão costuma sensibilizar o Poder Legislativo e também os autores da área jurídica que escrevem sobre educação costumam dar centralidade no problema da transmissão de conteúdos jurídicos indispensáveis para a conduta cidadã.

Gladston Mamede, no trecho abaixo descreve um quadro sombrio decorrente da falta de conhecimento em Direito:

Milhões de brasileiros vivem em pobreza política: não se lhes permitiu uma
educação apta a desenvolver um senso político e crítico Especificamente quanto
ao Direito, esse enorme contingente populacional vive em ignorância jurídica,
desconhecendo informações elementares que lhe tocam o cotidiano, como a Lei
do Inquilinato, normas sobre o poder de prisão, direitos trabalhistas etc. Chamar-
lhes de cidadão, nesse contexto, é pura retórica dentro de um mito de democracia
participativa que não possui condições mínimas de ser implementada
(...)(MAMEDE, p. 227)

Vejamos um outro exemplo bastante ilustrativo. Em um interessante trabalho monográfico, Rodrigo Costa Vidal Rangel ( 2008) discorre sobre a idéia de "Educação Constitucional" como preparo para o exercício da cidadania.

Naturalmente leva-se em conta uma formação que envolva o conhecimento dos dispositivos da Constituição da República, ou mais especificamente, segundo o autor, Educação constitucional é 
O processo pedagógico de ensino ao cidadão sobre valores e objetivos, direitos e deveres, Poderes, estrutura e entes da federação, institutos e princípios da Constituição da República de 1988, propiciando o exercício consciente e crítico da cidadania, legitimando, desta forma, a dimensão democrática do nosso Estado de Direito" (2008, p.89).

Note-se que há uma confiança muito grande no poder da informação a respeito de conteúdos de "natureza cidadã" e essa crença pode ser evidenciada com o seguinte trecho selecionado:

É tão farta a plêiade de direitos que a Constituição da República, expressa e implicitamente, nos oferta que se torna fácil imaginar e prever, como fato extremamente plausível, e até mesmo inexorável, que o cidadão, após ser educado constitucionalmente sobre seus direitos, irá exigir o devido respeito aos mesmos por parte do próximo e, principalmente, por parte do Estado brasileiro (...) (2008. p.60-61)

É “inexorável”, segundo o autor, que após o aprendizado dos conteúdos irá haver um comportamento sem hesitação do cidadão no sentido de exigir o respeito aos seus direitos fundamentais.

A necessidade de "informação" ou como já apontamos, de uma "conscientização" sobre direitos, sobre as normas em geral no tocante à educação para a cidadania é comentada por Lilian do Valle no seguinte excerto:

O conhecimento das leis aparece, recorrentemente, nos discursos educacionais sobre a formação do cidadão, como uma exigência, e corresponde ao mito iluminista segundo o qual ao conhecimento corresponde a virtude; em outras palavras, o vício e o pecado nada mais são do que condição da ignorância" (2004, p..228).

Há uma confiança na simples aprendizagem, como se a posse do conhecimento por si só conduzisse os homens a condutas morais irrepreensíveis. A iniciação nas coisas públicas se dão pelo acesso ao que é comum a todos, como a língua, por exemplo, e não a conhecimentos técnicos especializados.

A cidadania é uma formação e uma prática.

Sendo uma formação, valem as palavras de José Sérgio Fonseca de Carvalho:

É claro que todo processo de formação implica alguma aprendizagem, mas com ela não se confunde. A aprendizagem indica simplesmente que alguém veio a saber algo que não sabia: uma informação, um conceito, uma capacidade. Mas não implica que esse 'algo novo' que se aprendeu nos transformou em um novo 'alguém'. E essa é uma característica forte do conceito de formação: uma aprendizagem só é formativa na medida em que se opera transformações na 
constituição daquele que aprende. É como se o conceito de formação indicasse a forma pela qual nossa aprendizagens e experiências nos constituem como um ser singular no mundo.(2009)

E sendo um prática, não há como garantir em todos os casos que haverá apreço pelas instituições públicas, efetiva participação política além da obrigatoriedade de votar nas eleições periódicas, ou que mesmo que tudo se restrinja ao voto, que haverá empenho para exercê-lo da melhor forma.

Não há testes padronizados para avaliar o quesito "preparo para a cidadania" ao final das etapas finais do ensino básico, e mesmo que houvesse semelhante dispositivo, não seria possível por meio de respostas a conteúdos disciplinares considerados "formadores de cidadãos" (como por exemplo, organização do Estado, noções de direito, etc) atestar a qualidade do exercício da cidadania dos egressos do sistema escolar.

O que é sempre possível para a escola é a iniciação no mundo, na cultura e nas tradições públicas. 


\section{CONCLUSÃO}

Este trabalho se propôs a fazer uma abordagem interdisciplinar entre as áreas de Direito e Educação para tratar do tema da formação do cidadão segundo o art. 205 da Constituição de 1988. Refazendo o nosso itinerário, façamos um retorno a alguns pontos que foram desenvolvidos.

Fizemos, no primeiro capítulo, um trabalho de síntese para apresentar didaticamente uma noção de constituição que envolvesse, aspectos históricos, características gerais desse tipo de documento que é ao mesmo tempo jurídico e político, traçando uma pequena história sobre como a educação passou a ser assunto constitucional.

No Brasil, a primeira constituição a tratar da temática social e, em especial a sistematizar a educação na esfera constitucional, foi à carta de 1934.

A Constituição de 1988 é a primeira na história constitucional brasileira a enunciar a finalidade de educar para o exercício da cidadania, embora não tenha sido a primeira a indicar finalidades gerais para a educação, cuja primazia cabe à Constituição de 1934.

O art. 205 é classificado como uma norma constitucional de princípio ou programática. As normas constitucionais programáticas referem-se, de forma genérica, a indicações dos fins gerais da organização política instituída pela constituição, está impregnada de valores e aspirações da comunidade, e é um parâmetro a servir de guia para as decisões políticas e escolhas individuais. Do ponto de vista daqueles que legislam sobre matéria educacional, daqueles que estabelecem currículos e daqueles que atuam diretamente na prática educacional, sejam educadores ou responsáveis administrativos do setor, a finalidade de educar para o exercício da cidadania não é propriamente uma escolha ou uma liberalidade de menor importância, mas antes, reveste-se de indispensabilidade por estar expressa em uma norma constitucional de caráter teleológico, vinculada aos próprios fins do Estado Brasileiro.

Vimos no capítulo dois que no campo da Pedagogia, "educação" é um termo amplo, mas cujo significado mais recorrente é a formação dos indivíduos pela norma coletiva de convivência. A educação possui características políticas que lhes são inerentes, uma vez que preparam os mais jovens para assumir a responsabilidade por um mundo que lhes é anterior. "Ensino" é um termo ligado às atividades que são exercidas para produzir como resultado a aprendizagem. 
A Constituição de 1988 faz uso dos vocábulos “ensino" e "educação" de uma forma entendida por muito como aleatória e confusa. Em que pesem essa confusão terminológica e a aparente sinonímia dos termos, parece-nos que seria possível identificar dois sentidos básicos para educação no texto constitucional: um sentido de educação amplo, abarcando as ações mais globais que contribuem na formação geral do ser humano e um sentido estritamente escolar que muitas vezes (mas não sempre) recebe o nome de ensino.

Portanto, no texto constitucional, o uso do termo "ensino" está sempre atrelado à escolarização formal; já o termo “educação" aparece em alguns dispositivos nesse mesmo significado estritamente escolar e em outros aparece em sentido amplo.

No capítulo três, verificamos que a cidadania é um termo polissêmico: pode ser vista de forma restrita como um conjunto de direitos e deveres que envolvem a participação política em uma democracia representativa, em especial o direito-dever de votar periodicamente; cidadania pode ser encarada de forma ampliada, incluindo não só direitos políticos em sentido estrito, como também envolvendo a fruição de direitos de natureza econômica e social (direito ao trabalho, direito à educação, direito à saúde). Cidadania se refere à condição de cidadão, pessoa física, mas há o uso do termo cidadania para ações corporativas exercidas por empresas, interessadas em criar uma boa imagem diante dos seus clientes. Cidadania revela-se como um vínculo a um corpo político materializado em Estado-nação, mas há referências a uma cidadania global em que há um compromisso difuso com os destinos da humanidade como um todo. Há uma expressão de cidadania que se parece com urbanidade, ou "educação" no sentido de boas maneiras como a divulgação de máximas como "seja um cidadão consciente, deixe os idosos entrarem primeiro no elevador".

Ainda no capítulo três, traçamos um histórico da noção de cidadania desde a Antigüidade greco-romana, passando pelo Estado Liberal até a formação do Estado de Bem Estar Social. Em linhas gerais, a cidadania antiga se caracterizava pela participação ativa na vida pública, por sua vez a cidadania de cunho liberal privilegiava a proteção jurídica do particular contra a interferência do Estado ficando a participação política restrita à representação, e por fim o Estado de Bem Estar fixa-se na noção de cidadania enquanto um conjunto de direitos civis, políticos e, principalmente, sociais.

A Constituição brasileira não apresenta um conceito de cidadania, entretanto, as diversas indicações do papel do cidadão nos permite compor algumas de suas dimensões, que vão além do voto. 
Em termos constitucionais, podemos identificar a cidadania como um conjunto de direitos e deveres que permitem, entre outras atividades, a participação política na gestão dos negócios públicos por meio dos instrumentos da democracia representativa (voto, candidatura a cargos públicos) e por meio de instrumentos de democracia semi-direta (plebiscito, referendo e iniciativa popular); participação em órgãos, conselhos, comitês gestores que auxiliam na gestão das ações do Poder Público; o exercício da fiscalização do poder; a reivindicação de direitos frente aos poderes públicos.

No capítulo quatro foi abordado o declínio da atividade política no mundo contemporâneo esvaziando o sentido de cidadania participativa em nome da figura do consumidor. A perda do "senso comum" o obscurecimento do espaço público e a ascensão da esfera social, conforme as categorias de análise de Hannah Arendt, nos revelam um tempo em que a política perdeu a sua relevância engolfada pelo império das necessidades de sobrevivência.

A situação de hostilidade em relação ao mundo público encontra convergência com as análises sobre o perfil do meio social brasileiro, as características indicativas de uma sociedade hierárquica, patrimonialista, desigual, pouco afeita a exigências de natureza pública. Os inúmeros trabalhos clássicos em nossa historiografia que sinalizam nessa direção, aparentemente, não foram desmentidos.

Finalmente no capítulo cinco, discutimos o impasse gerado pelo paradoxo de vivermos em uma sociedade que desvaloriza a política e a retórica da educação para a cidadania levando em conta a idéia de uma formação voltada para a participação na esfera pública. 


\section{REFERÊNCIAS}

ADORNO, Theodor W. Educação e emancipação. $4^{\mathrm{a}}$ Ed. Trad. Wolfgang Leo Maar. São Paulo: Paz e Terra, 2006.

ALVAREZ, Anselmo Prieto, NOVAES FILHO, Wladimir. A Constituição dos EUA: anotada. São Paulo, LTr, 2001.

AMARAL, Jussara de Fátima. A eficácia da cidadania. Cadernos de Direito Constitucional e Ciência Política, n.14, p.204-211, jan./mar. 1996.

ALMEIDA, Alberto Carlos. A cabeça do brasileiro. 2. ed. Rio de Janeiro, Record, 2007.

ANDRADE, Vera Regina Pereira de. Cidadania: do direito aos direitos humanos. São Paulo: Editora Acadêmica, 1993.

- Cidadania, direitos humanos e democracia: reconstruindo o conceito liberal de cidadania. In: SILVA, Reinaldo Pereira e (Org.). Direitos humanos como educação para a justiça . São Paulo: LTr, 1998.[

AQUINO, Julio Groppa. Do cotidiano escolar: Ensaios sobre ética e seus avessos. São Paulo: Summus, 2000.

APAP, Georges...[et al.]. A construção dos saberes e da cidadania: da escola à cidade. Trad. Claudia Schilling. Porto Alegre: Artmed, 2002

ARENDT, Hannah. Sobre a revolução. Trad. I. Morais.Lisboa: Relógio D’Água, 2001. A condição humana.10.ed.Trad. Roberto Raposo.Rio de Janeiro: Forense Universitária, 2005a.

Entre o passado e o futuro. 5.ed. Trad. Mauro W. Barbosa. São Paulo: Editora Perspectiva, 2005b.

As origens do totalitarismo.Trad. Roberto Raposo. São Paulo: Companhia das Letras, 2007.

.Homens em tempos sombrios.Trad. Denise Bottmann. São Paulo: Comapanhia das Letras, 2008.

ARISTÓTELES. Política. 3.ed.Trad. Mário da Gama Kury. Brasília: Editora UnB, 1997.

ASSIS, Joaquim Maria Machado. Obras completas de Machado de Assis. $1^{\circ}$ volume de "A Semana" (1892-1893). São Paulo: Jackson, 1957.

Obras completas de Machado de Assis. 3 volume de "A Semana" (1895-1900).

São Paulo: Jackson, 1957.

BALLARINO, Tito. Cidadania e Nacionalidade. In: DAL RI JÚNIOR, Arno, OLIVEIRA, Odete Maria. Cidadania e Nacionalidade: efeitos e perspectivas nacionais-regionaisglobais. 2. ed.Ijuí: Editora Unijuí,2003. 
BARACHO, José Alfredo de Oliveira. Teoria geral da cidadania: a plenitude da cidadania e as garantias constitucionais e processuais. São Paulo: Saraiva, 1995.

BARRETO, Vicente. O conceito moderno de cidadania. Revista de Direito Administrativo, vol. 192, p.29- 37, abr./jun.1993.

BARROS, Gilda Naécia Maciel de. O exercício da cidadania como forma superior de humanismo. In: Platão, Rousseau e o Estado Total. São Paulo: T.A. Queiroz, 1996.

BARROS, Roque Spencer Maciel de. Ainda a participação. In: Estudos Liberais. São Paulo: T.A.Queiroz, 1992.

BARROSO, Luis Roberto. Constituição da República Federativa do Brasil Anotada. 5.ed. reform. São Paulo: Saraiva, 2006a

.Constituição. In: BARRETO, Vicente de Paulo (COORD.). Dicionário de filosofia do direito.São Leopoldo: Editora UNISINOS, 2006b.

.O direito constitucional e a efetividade de suas normas:limites e possibilidades da Constituição Brasileira. 9.a. Rio de Janeiro: Renovar, 2009.

BASTOS, Celso Ribeiro; MARTINS, Ives Gandra. Comentário à Constituição do Brasil,vol 3, arts 24 a 36. São Paulo: Saraiva, 1993.

.Curso de Direito Constitucional. 21.ed.atual.São Paulo: Saraiva, 2000.

BENDIX, Reinhard. Construção nacional e cidadania: estudos de nossa ordem social em mudança. Trad. Mary Amazonas Leite de Barros. São Paulo: Editora da Universidade de São Paulo, 1996.

BENEVIDES, Maria Victoria Mesquita. A cidadania ativa: referendo, plebiscito e iniciativa popular. São Paulo: Ática, 1991.

.Cidadania e democracia. Revista Lua Nova, São Paulo, n. 33, p. 5-16, 1994.

.O desafio da educação para a cidadania.In: AQUINO, Julio Groppa (Org.).

Diferenças e preconceito na escola.8.ed. São Paulo: Summus, 1998.

Educação em direitos humanos: de que se trata? Seminário de Educação em Direitos Humanos: Palestra de abertura (18/02/2000), São Paulo, S.ed., 2000a. (mimeo.)

BENJAMIN, Walter. Sobre o conceito de história.In: BENJAMIN, Walter. Obras Escolhidas I. 7.edSão Paulo: Brasiliense., 1994.

BITTAR, Eduardo C. B. Ética, educação, cidadania e direitos humanos: estudos filosóficos entre cosmopolitismo e responsabilidade social. Barueri: Manole, 2004.

BOAVENTURA, Edivaldo M. A.. A educação nos 50 anos da Constituição de 1946. Revista de Informação Legislativa, Brasília, ano 33, n. 132, out./dez. 1996.

A Constituição e a educação brasileira. Revista de Informação Legislativa, Brasília, ano 32, n. 127, jul./set. 1995.

BOBBIO, Norberto. A era dos direitos. Trad. Nelson Coutinho.Rio de Janeiro: Elsevier, 2004 
2006.

O futuro da democracia.Trad. Marco Aurélio Nogueira. São Paulo: Paz e Terra,

BONAVIDES, Paulo, ANDRADE, Paes. História constitucional do Brasil. Brasília: OAB editora, 2008.

BORBA, F. da S. Dicionário dos usos do Português. São Paulo: Ática, 2002.

BOVERO, Michelangelo. Contra o governo dos piores: uma gramática da democracia. Trad. Daniela Beccaccia Versiani. Rio de Janeiro: Campus, 2002.

BRITO FILHO, José Claudio. Direitos Humanos: algumas questões recorrentes: em busca de uma classificação jurídica. In:ROCHA, João Carlos de Carvalho, Henriques Filho, Tarcísico Humberto Parreira, CAZETTA, Ubiratan, (Coords.). Direitos Humanos: desafios humanitários contemporâneos: 10 anos do Estatuto dos Refugiados (Lei n. 9474 de 22 de julho de 1997). Belo Horizonte: Del Rey, 2008.

BULOS, Uadi Lammêgo. Constituição Federal Anotada. 7.ed.rev.e atual. São Paulo: Saraiva, 2007.

CANDAU, Vera Maria et alii. Sociedade, direitos humanos e cidadania: desafios para a educação no Brasil. In: SACAVINO, Susana; CANDAU, Vera Maria (Org.). Educação em direitos humanos.Petrópolis: DP et Alli Editora, 2008.

CANIVEZ, Patrice. Educar o cidadão?Trad. Estela do Santos Abreu e Cláudio Santoro. Campinas: Papirus, 1991.

CARVALHO, A. Dardeau de.Nacionalidade e cidadania: Lei nº18, de 18 de setembro de 1949. Rio de Janeiro: Freitas Bastos, 1950.

CARVALHO, José Murilo de. Interesses contra a cidadania. In: DAMATTA, Roberto [et alii]. Brasileiro: Cidadão? São Paulo: Cultura Editores Associados, 1992.

. O motivo edênico no imaginário social brasileiro. In:PANDOLFI, Dulce Chaves et al. (Orgs.). Cidadania, justiça e violência. Rio de Janeiro: Ed. Fundação Getúlio Vargas, 1999.

A formação das almas: o imaginário da República no Brasil. 18. reimp. São Paulo: Companhia das Letras, 2008. das Letras, 2009.

Os Bestializados:O Rio de Janeiro e a República que não foi. São Paulo: Comapnhia

CARVALHO, José Sérgio Fonseca. Sobre a pertinência de uma filosofia do ensino.Cad. :Hist. Filos. Educ., vol IV, n6, p.213-238, 2001.

. (Org.). Educação, cidadania e direitos humanos. Petrópolis: Editora Vozes, 2004a.

.Democratização do Ensino" revisitado. Educação e Pesquisa, v.30, n.2, p. 327334, mai./ago. 2004b.

. A qualidade de ensino vinculada à democratização do acesso à escola. Revista Estudos Avançados . Vol. 21, n.60, p. 307-310 mai./ago.2007b. 
.Direitos humanos, formação escolar e esfera pública. In:BITTAR, Eduardo C. B (Coord.)..Educação e metodologia para os direitos humanos. São Paulo: Quartier Latin, 2008.

. Sobre o conceito de formação. . Educação [Revista]. São Paulo, n.137, dez./2009.Acessível em:http://revistaeducacao.uol.com.br/textos.asp?codigo $=12511$

CASTRO, Claudio de Moura. "Educação não é mercadoria” .Revista Veja, 9/04/2008, p.20

CESAR, Monica de Jesus. "Empresa-cidadã”: uma estratégia de hegemonia. São Paulo: Cortez, 2008.

CICERO, Marco Túlio. Da República. Trad. Amador Cisneiros. In: Os Pensadores. 1.ed, vol V. São Paulo:Abril cultural, 1973

CINTRA, Geraldo Ulhôa. De statu civitatis: alguns aspectos da cidadania romana.São Paulo: Revista dos Tribunais, 1963.

COMPARATO, Fábio Konder. .A afirmação histórica dos direitos humanos. 5. ed. rev. e atual. São Paulo: Saraiva, 2007.

.A nova cidadania. Revista Lua Nova, São Paulo, n. 28/29, p. 85-106, 1993.

CORRÊA,Darcísio. A Construção da cidadania: reflexões histórico-políticas.4.ed..Ijuí:

Editora Unijuí, 2006.

CORTINA, Adela. Cidadãos do mundo: para uma teoria da cidadania. Trad. Silvana Cobucci Leite. São Paulo: Loyola, 2005.

COSTA, Emilia Viotti da. O Supremo Tribunal Federal e a construção da cidadania. 2.ed.São Paulo: Editora UNESP, 2006.

CUNHA, Antônio Geraldo da. [et. al.] Dicionário etimológico Nova Fronteira da língua portuguesa. 2.ed. Rio de Janeiro: Nova Fronteira, 1997.

DAGNINO, Evelina. Os movimentos sociais e a emergência de uma nova noção de cidadania. In: DAGNINO, Evelina (Org.). Anos 90: política e sociedade no Brasil.São Paulo: Brasiliense, 2004.

DAHRENDORF, Ralf. O conflito social moderno : um ensaio sobre a política da liberdade. Trad. Renato Aguiar, Marco Antonio Esteves da Rocha. Rio de Janeiro: Zahar, São Paulo: EDUSP, 1992.

DALLARI, Dalmo de Abreu. Ser cidadão. Revista Lua Nova,São Paulo, vol. 1, n², p. 6164, jul./set. 1984.

.Constituição e constituinte.3.ed. São Paulo: Saraiva, 1986. . Elementos de teoria geral do Estado. 23. ed.São Paulo: Saraiva, 2002.

DAMATTA, Roberto [et alii]. Brasileiro: Cidadão? São Paulo: Cultura Editores Associados, 1992 . A casa \& a rua : espaço, cidadania, mulher e morte no Brasil. 5.ed. Rio de Janeiro:Rocco, 1997. 
DELGADO, Omar Carrasco. Construção da cidadania por meio do discurso escolar. Vitória: Gráfica Ita, 1997.

DIMENSTEIN, Gilberto. Cidadão de papel: a infância, a adolescência e os Direitos Humanos no Brasil. 20.ed.São Paulo: Editora Ática, 2002.

DINIZ, Maria Helena Dicionário Jurídico. São Paulo: Saraiva, 2008. 4 v. Norma constitucional e seus efeitos.São Paulo: Saraiva, 1998.

DUARTE, André. Hannah Arendt e a modernidade: esquecimento e redescoberta política.In: CORREIA, Adriano (Coord.). Transpondo o abismo : Hannah Arendt entre a filosofia e a política. Rio de Janeiro: Forense Universitária, 2002.

DUMONT, Louis. $O$ individualismo: uma perspectiva antropológica da ideologia moderna. Trad.Álvaro Cabral. Rio de Janeiro: Rocco, 1985.

DURKHEIM, Émile. Educação e sociologia.Trad. Nuno Garcia Lopes.Lisboa:Edições 70, 2007.

ESPADA, João Carlos. Direitos sociais de cidadania. São Paulo: Massao Ohno Editor, 1999.

FERRAJOLI, Luigi.Los fundamentos de los derechos fundamentales.3.ed.

Madrid:Editorial Trotta, 2007

FERREIRA, Pinto. Curso de Direito Constitucional. 12.ed. ampl. atual. São Paulo: Saraiva, 2002.

FERREIRA FILHO. Manoel Gonçalves.Curso de Direito Constitucional. 30.ed. São Paulo: Saraiva, 2003.

FINLEY, M. I. (Org.). O legado da Grécia: uma nova avaliação. Trad. Yvette Vieira Pinto de Almeida. Brasília: Editora Universidade de Brasília, 1998.

FUNARI, Pedro Paulo. A cidadania entre os romanos. In: PINSKY, Jaime, PINSKY, Carla Bassanezi (Orgs.). História da cidadania 4.ed. São Paulo: Editora Contexto, 2008.

GARCIA, Maria. Educação, cultura e desporto (arts. 205 a 217). In:TANAKA,Sônia Yuriko Kanashiro (Coord.).Direito Constitucional. São Paulo: Malheiros, 2009.

GOMES, Angela de Castro (Coord.). Direitos e Cidadania: memória, política e cultura. Rio de Janeiro: Editora FGV, 2007.

GUARINELLO, Norberto Luiz. Cidades-estado na Antigüidade Clássica.In: PINSKY, Jaime, PINSKY, Carla Bassanezi (Orgs.). História da cidadania 4.ed. São Paulo: Editora Contexto, 2008.

HANNOUN, Hubert. Nazismo: educação? Domesticação?Trad. Fátima e Carlos Gaspar.Lisboa: Instituo Piaget, 1997.

HERKENHOFF, João Baptista. Cidadania para todos : O que toda pessoa precisa saber a respeito de cidadania.Rio de Janeiro: Thex Editora, 2002 
HIRST, P.H., PETERS, R. S. A lógica da educação. Trad. Edmond Jorge. Rio de Janeiro: Zahar, 1972.

HOBSBAWN, Eric J. A Revolução Francesa .Trad. Maria Tereza Lopes Teixeira e Marcos Penchel. Rio de Janeiro: Paz e Terra, 2004.

HOLLANDA, Sérgio Buarque de. Raízes do Brasil. 26.ed.São Paulo: Companhia das Letras, 2009.

HOUAISS, Antonio. Dicionário Houaiss da Língua Portuguesa. Rio de Janeiro: Objetiva, 2001.

HUNT, Lynn.A invenção dos direitos humanos:uma história.Trad. Rosaura Eichenberg.São Paulo:Companhia das Letras, 2009

INDURSKY, Freda. O Cidadão na III ${ }^{a}$ República Brasileira.In: GUMARÃES, Eduardo, ORLANDI, Eni Puccinell (Orgs.). Língua e Cidadania: o português no Brasil. Campinas: Pontes, 1996.

JAEGER, Werner. Paidéia: a formação do homem grego. 4. ed. Trad. Arthur M. Parreira. São Paulo: Martins Fontes, 2003.

KANT, IMMANUEL.Sobre a pedagogia. Trad. Francisco Cock Fontanella. 5.ed.Piracicaba: Editora UNIMEP, 2006.

KARNAL, Leandro. Estados Unidos, liberdade e cidadania. In: PINSKY, Jaime, PINSKY, Carla Bassanezi (orgs.). História da cidadania 4.ed. São Paulo: Editora Contexto, 2008.

KYMLICKA, Will;NORMAN, Wayne.Return of the citzen.In: In:BEINER, Ronald(Org.). Theorizing Citizenship. Albany: State University of New York Press, 1995.

LAFER, Celso.Hannah Arendt: pensamento, persuasão e poder.2.ed. São Paulo: Paz e Terra, 2003.

. A reconstrução dos direitos humanos: um diálogo com o pensamento de Hannah Arendt. 6. reimp. São Paulo: Companhia das Letras, 2006a.

A internacionalização dos direitos humanos: o desafio do direito a ter direitos. Revista TRF $3^{\text {a }}$ Região, São Paulo, vol.75, p.37-54, jan./ fev.2006b.

LASSALLE, Ferdinand. Que é uma constituição? Trad. Walter Stönner. Porto Alegre: Villa Martha, 1980.

LIBERATI, Wilson Donizeti (Org.). Direito à educação: uma questão de justiça. São Paulo: Malheiros, 2004.

LOCKE, John. Segundo tratado sobre o governo. Trad. E. Jacy Monteiro. In: Os Pensadores. 3.ed. São Paulo:Abril cultural, 1973.

LOPES, Ana Maria D’Ávila. A cidadania na Constituição Federal Brasileira de 1988: redefinindo a participação política. In:BONAVIDES, Paulo, LIMA, Francisco Gérson Marques de, BEDÊ, Fayga Silveira. Constituição e democracia: estudos em homenagem ao Prof. J. J, Gomes Canotilho. São Paulo: Malheiros, 2006. 
LOSURDO, Domenico. Democracia ou bonapartismo: triunfo e decadência do sufrágio universal. Trad. Luiz Sérgio Henriques. Rio de Janeiro: Editora UFRJ: UNESP, 2004.

MACHADO, Nílson José.Qualidade na educação: as armadilhas do óbvio. In: Pensando e Fazendo Educação de Qualidade. São Paulo: Editora Mdoerna, 2001.

. Cidadania e educação. 4. ed. São Paulo: Escrituras Editora, 2002.

MALISKA, Marcos Augusto. O direito à educação e a constituição. Porto Alegre: Sérgio Antonio Fabris Editor, 2001.

MAMEDE, Gladston. Hipocrisia: o mito da cidadania no Brasil. Revista de Informação Legislativa, Brasília, n.134, p. 219-229, abr./jun.1997.

MARSHALL, T.H. Cidadania, classe social e status . Trad. Meton Porto Gadelha. Rio de Janeiro: Zahar, 1967.

MANZINI-COVRE, Maria de Lourdes (Org.). A cidadania que não temos.São Paulo: Brasiliense, 1986.

O que é cidadania?3.ed.16. reimp. São Paulo: Brasiliense, 2008.

MAZZUOLI, Valério de Oliveira. Direitos humanos e cidadania: à luz do novo direito internacional. Campinas: Minelli, 2002.

MEIRELLES, Hely Lopes. Mandado de Segurança. 28.ed.São Paulo: Malheiros, 2005.

MESSIAS, Francisco das Chagas Gil. Cidadania e Censura Política no Estado Autoritário Brasileiro (1964-1979). Dissertação (Mestrado em Ciências Humanas- Especialidade Direito). Universidade Federal de Santa Catarina, Florianópolis, 1981.

MELLO, Celso Antônio Bandeira de. Eficácia das normas constitucionais e direitos sociais. São Paulo: Malheiros, 2009.

MIRANDA, Jorge. Teoria do Estado e da Constituição. 2.ed. rev. atual.Rio de Janeiro: Forense, 2009.

MONTESQUIEU, Charles de Secondat, Baron de. O espírito da leis.3.ed.Trad. Cristina Murachco. São Paulo: Martins Fontes, 2005.

MUNIZ, Regina Maria Fonseca. O Direito à Educação. Rio de Janeiro: Renovar, 2002.

NASCIMENTO, Edna Maria F. dos Santos , GREGORIN FILHO, José Nicolau. LDB, Ensino superior e Construção da cidadania. São Paulo: Ed. Plêiade, 2000.

NASCIMENTO, Mariângela. A esfera pública na democracia brasileira: uma reflexão arendtiana. In: CORREIA, Adriano, NASCIMENTO Mariângela (Org.). Entre o passado e o futuro. Juiz de Fora: UFJF, 2008.

OAKESHOTT, Michael. Aprendizaje Y enseñanza.In:PETERS, R.S.El concepto de educacion.Buenos Aires:Paidos, 1969.

OLIVEIRA, Sheila Elias. Cidadania: história e política de uma palavra. Campinas: Pontes Editores: RG Editores, 2006. 
PANDOLFI, Dulce Chaves et al. (Orgs.). Cidadania, justiça e violência. Rio de Janeiro: Ed. Fundação Getúlio Vargas, 1999.

PARADA, Maurício. Educando corpos e criando a nação: cerimônias cívicas e práticas disciplinares no Estado Novo. Rio de Janeiro: Ed. PUC-Rio:Apicuri, 2009.

PATTO, Maria Helena Souza (Org.). A Cidadania negada: políticas públicas e formas de viver.São Paulo: Casa do Psicólogo, 2009.

PEREIRA, Luiz Carlos Bresser. Cidadania e res publica: a emergência dos direitos republicanos.Revista de Informação Legislativa, Brasília, a. 34, n. 136, out/dez. 1997.

PIERDONÁ, Zélia Luiza. Objetivos Constitucionais da Educação e sua relação com os fundamentos do Estado Brasileiro.In:FERREIRA, Dâmares(Coord.).Direito educacional em debate. vol 1.São Paulo: Cobra Editora, 2004.

PINSKY, Jaime. Cidadania e Educação.8.ed.São Paulo: Editora Contexto, 2003.

PIOVESAN, Flávia. Temas de Direitos Humanos. São Paulo: Max Limonad, 2003.

POCOCK,J. G. A.The Ideal of Citzenship Since Classical Times. In:BEINER, Ronald(Org.). Theorizing Citizenship. Albany: State University of New York Press, 1995.

RANGEL, Rodrigo Costa Vidal. Educação constitucional, cidadania e estado Democrático de Direito. Porto Alegre: Nuria Fabris, 2008.

RANIERI, Nina Beatriz Stocco. Educação superior, direito e Estado.São Paulo: Editora da Universidade de São Paulo, 2000.

REIS, Elisa. Cidadania do Trabalhador rural. In:TEIXEIRA, João Gabriel Lima Cruz. $A$ construção da cidadania. Brasília: Editora Universidade de Brasília, 1986.

.Cidadania: história, teoria e utopia. In:PANDOLFI, Dulce Chaves et al. (Orgs.). Cidadania, justiça e violência. Rio de Janeiro: Ed. Fundação Getúlio Vargas, 1999.

REIS, Fábio Wanderley.O Estado, o mercado e cidadania democrática. Trad. Ana Luiza Pinheiro.In:JELIN, Elizabeth; HERSHBERG, Eric. Construindo a democracia:direitos humanos, cidadania e sociedade na América Latina.São Paulo: Editora da Universidade de São Paulo: Núcleo de Estudos da Violência,2006.

RESENDE, Ênio J.Cidadania :o remédio para doenças culturais brasileiras. 2.ed.São Paulo: Summus, 1992.

RIBEIRO, Ivan César. Robin Hood versus King John: como os juízes locais decidem casos no Brasil. Disponível em

,http://www.ipea.gov.br/ipeacaixa/premio2006/docs/trabpremiados/IpeaCaixa2006_Profiss ional_01lugar_tema01.pdf>. Acesso em: jun.2008.

RIBEIRO, Renato Janine. A república. São Paulo: Publifolha, 2001.

.Democracia versus república:a questão do desejos nas lutas sociais.In:

BIGNOTTO, Newton. Pensar a república . Belo Horizonte: Ed UFMG, 2002.

.A política como espetáculo. In: DAGNINO, Evelina (Org.). Anos 90 : política e sociedade no Brasil. São Paulo: Brasiliense, 2004. 
.In: RIFIOTIS, Theophilos, Tiago Hyra Rodrigues (Ors.).Educação em direitos humanos. Florianópolis: Ed da UFSC, 2008.

SANI, Giacomo. Participação política. In: BOBBIO, Norberto, MATEUCCI, Nicola, PASQUINO, Gianfranco (orgs.) Dicionário de Política. 13.ed. Brasília: Editora UnB, 2008, vol. 2

SANTOS, Milton. O espaço do cidadão. 7. ed. São Paulo: EDUSP, 2007.

SENNETT, Richard. Carne e Pedra: o corpo e a cidade na civilização ocidental.

4..ed.Trad. Marcos Aarão Reis. Rio de Janeiro: Record, 2006.

SCHEFFLER, Israel. A linguagem da educação. Trad. Balthazar Barbosa Filho. São Paulo: Saraiva: Editora da Universidade de São Paulo, 1974.

SIEYÈS, Emmanuel Joseph. Exposição Refletida dos Direitos do Homem e do Cidadão. Trad. Emerson Garcia.Rio de Janeiro: Lumen Juris, 2008.

. A constituinte burguesa: Qu' est-ce que Le Tiers État? Trad. Norma Azevedo. Rio de Janeiro: Lumen Juris, 2009.

SILVA, José Afonso da. Ação popular constitucional: Doutrina e Processo. $2^{\text {a }}$.ed.rev.ampl. e aum.São Paulo: Malheiros, 2007a.

.Faculdades de direito e construção da cidadania. In: SILVA, José Afonso da. Poder constituinte e poder popular: estudos sobre a Constituição. São Paulo: Malheiros, 2007b. 2008.

.Curso de direito constitucional positivo. 30.a.ed. rev. atual. São Paulo: Malheiros,

. Comentário Contextual à Constituição. 6. ed. São Paulo: Malheiros, 2009.

SPINK, Mary Jane Paris (Org.). A cidadania em construção: uma reflexão transdisciplinar. São Paulo: Cortez, 1994.

TEIXEIRA, João Gabriel Lima Cruz (Coord.) A Construção da cidadania. Brasília: Universidade de Brasília, 1986.

TEBET, Simone Nassar. O princípio da democracia e o exercício da cidadania: realidade ou ficção? Cadernos de Direito Constitucional e Ciência Política, n.14, p.231-248, jan./mar. 1996.

TELLES, Vera Silva. As novas faces da cidadania: introdução. Cadernos de Pesquisa. n. 04 - Novas Faces da Cidadania: Identidades Políticas e Estratégias Culturais.São Paulo: CEBRAP, jun. 1996. (Acessível em www.cebrap.org.br.)

. Política e espaço público na constituição do "mundo comum": notas sobre o pensamento de Hanna Arendt. In: TELLES, Vera Silva. Direitos Sociais: Afinal do que se trata? Belo Horizonte: Editora UFMG, 1999.

TOMASEVSKI, Katarina. Por que a educação não é gratuita? IN: HADDAD, Sérgio, GRACIANO, Mariângela (Org.). A Educação entre os direitos humanos. Campinas: Autores Associados, 2006. 
TORRES, Ricardo Lobo. A cidadania multidimensional na era dos direitos. In: TORRES, Ricardo Lobo (Org.) Teoria dos Direitos Fundamentais. Rio de Janeiro: Renovar, 1999.

VAIDEGORN, José. (Org.).O direito a ter direitos.Campinas: Autores Associados, 2000.

VAINFAS, Ronaldo (direção). Dicionário do Brasil Colonial (1500-1808). Rio de Janeiro: 2000.

VALCÁRCEL, Amelia. Ética contra estética. Trad. Newton Cunha. São Paulo: Perspectiva:SESC, 2005.

VALLE, Lílian do. Cidadania e escola pública.In. VALLE, Lílian (Org.).. O mesmo e o outro da cidadania.Rio de Janeiro: DP\&A, 2000.

.Modelos de cidadania e discursos sobre a educação.2.ed.In: PEIXOTO, AdãoJosé.Filosofia Educação e Cidadania.Campinas: Alínea, 2004.

VERNANT, Jean-Pierre. As origens do pensamento grego. 18.a ed. Trad. Ísis Borges B. da Fonseca. Rio de Janeiro: Difel, 2009.

VIEIRA, José Ribas. A cidadania: sua complexidade teoria e o Direito. Revista de Informação Legislativa, Brasília, ano 34, n. 135, p. 219-224, jul./set. 1997.

VIEIRA, Liszt.Cidadania e Globalização. Rio de Janeiro: Record. 1998 . Os Argonautas da cidadania: a sociedade civil na globalização. Rio de Janeiro: Record, 2001

VIVARTA, Veet. Cidadania antes dos 7 anos: a educação infantil e os meios de comunicação. São Paulo: Cortez, 2003.

WEIL, Simone. O desenraizamento operário. In: BOSI, Ecléa (Org.).Simone Weil: A condição operária e outros estudos sobre a opressão.2.ed.São Paulo: Paz e Terra, 1996. 